
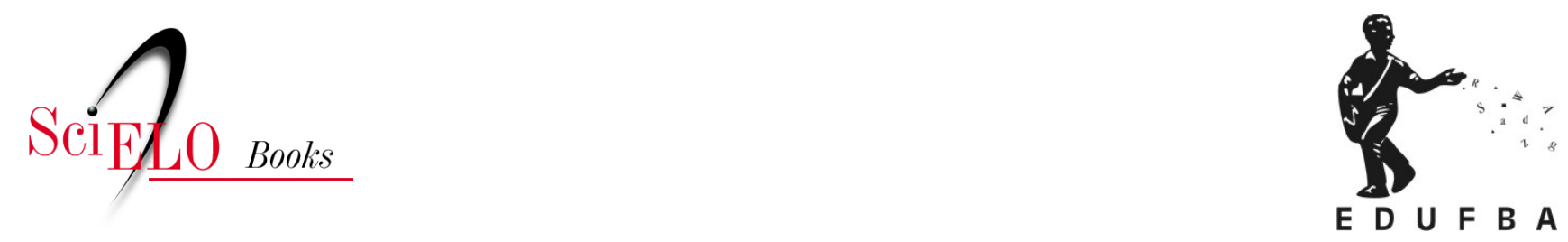

\title{
Hip-hop feminista? \\ Convenções de gênero e feminismos no movimento Hip-hop soteropolitano
}

\author{
Rebeca Sobral Freire
}

\section{SciELO Books / SciELO Livros / SciELO Libros}

FREIRE, R.S. Hip-hop feminista? Convenções de gênero e feminismos no movimento Hip-hop soteropolitano [online]. Salvador: EDUFBA/NEIM, 2018. Bahianas collection, n. 20, 212 p. ISBN: 978-85-232-1862-1. https://doi.org/10.7476/9788523218621.

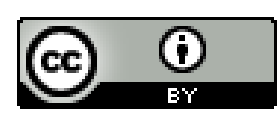

All the contents of this work, except where otherwise noted, is licensed under a Creative Commons Attribution $\underline{4.0 \text { International license. }}$

Todo o conteúdo deste trabalho, exceto quando houver ressalva, é publicado sob a licença $\underline{\text { Creative Commons }}$ Atribição 4.0. 



\section{UNIVERSIDADE FEDERAL DA BAHIA}

Reitor

João Carlos Salles Pires da Silva

Vice-Reitor

Paulo Cesar Miguez de Oliveira

Acessor do Reitor

Paulo Costa Lima

\section{NÚCLEO \\ INTERDISCIPLINARES \\ SOBRE A MULHER}

FFCH/UFBA

NEIM

Diretora

Márcia Macêdo

vice-diretora

Silvia Lúcia Ferreira

Comissão Editorial

Alda Britto da Motta

Ana Alice Alcântara Costa

Cecília M. B. Sardenberg

Enilda R. do Nascimento

Ivia Alves

Silvia Lúcia Ferreira

Coordenação Editorial Executiva

Eulália Azevedo

Ivia Alves

Maria de Lourdes Schefler

Silvia de Aquino

Ângela Lima e Souza

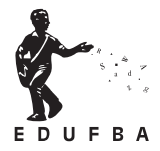

EDITORA DA UNIVERSIDADE FEDERAL

DA BAHIA

Diretora

Flávia Goullart Mota Garcia Rosa

\section{Conselho Editorial}

\section{Titulares}

Alberto Brum Novaes

Angelo Szaniecki Perret Serpa

Caiuby Alves da Costa

Charbel Niño El-Hani

Cleise Furtado Mendes

Evelina de Carvalho Sá Hoisel

José Teixeira Cavalcante Filho

Maria do Carmo Soares de Freitas

Maria Vidal de Negreiros Camargo 
Rebeca Sobral Freire

\section{Hip-hop feminista?}

Convenções de gênero e feminismos no movimento Hip-hop soteropolitano

COLEÇÃOBahianas, 20

Salvador | EDUFBA/NEIM | 2018 
2018, Autores.

Direitos para esta edição cedidos à Edufba.

Feito o Depósito Legal.

Grafia atualizada conforme o Acordo Ortográfico da Língua Portuguesa de 1990, em vigor no Brasil desde 2009.

\author{
Projeto gráfico \\ Alana Gonçalves de Carvalho Martins \\ Editoração \\ Marcella Napoli \\ Revisão e normalização \\ Lia Nery \\ Jade Santos
}

A publicação deste livro contou com recursos da Emenda Parlamentar de autoria da Deputada Lídice da Mata.

Os conteúdos dos artigos são da inteira responsabilidade dos seus autores

NEIM

F866

Hip-hop feminista?: Convenções de gênero e feminismos no movimento Hip-hop soteropolitano / Rebeca Sobral Freire. - Salvador, EDUFBA/NEIM, 2018.

212 p. - (Coleção Bahianas, 20)

Universidade Federal da Bahia, Faculdade de Filosofia e Ciências Humanas, Programa de Pós-graduação Interdisciplinar sobre gênero, mulheres e feminismo. Orientação da Profa. Dra. Alinne Bonetti defendida em 2018.

ISBN: 978-85-232-1782-2

1. Mulheres - aspectos sociológicos. 2. Feminismo. 3. Hip Hop (cultura popular). I. Bonetti, Alinne. II. Universidade Federal da Bahia, Faculdade de Filosofia e Ciências Humanas. III. Título.

CDD -305.4

Editora filiada à

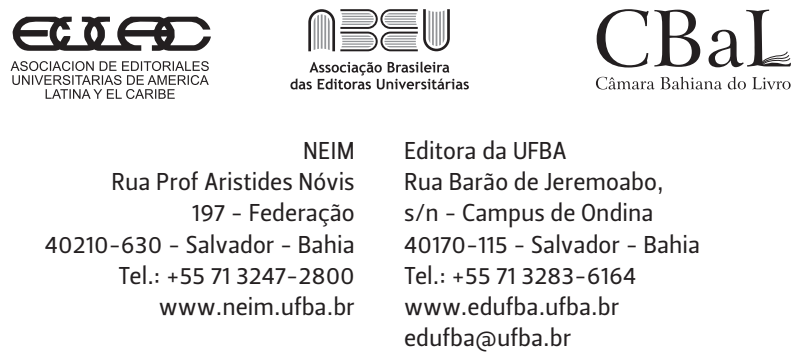


Com carinho, dedico este livro ao meu querido power trio, in memorian, Minha mãe, Socorro Sobral, Profa. Dra. Ana Alice Alcantara Costa, e Ministra Luiza Bairros. Às hip hoppers soteropolitanas! À Salvador, Bahia! À nossa universidade pública, UFBA!

Gratidão! 


\section{AGRADECIMENTOS}

Este livro discute questões em torno das convenções de gênero e feminismos no hip-hop em Salvador a partir da perspectiva das jovens militantes, interessado em analisar a possibilidade de um hip-hop feminista soteropolitano, com vistas à compreensão do feminismo na sua pluralidade como movimento social. Para tanto, considera-se as formas de apropriação dos discursos feministas e o engajamento em suas bandeiras na militância das interlocutoras da pesquisa.

Ressalta-se a atenção à articulação entre os marcadores sociais de gênero, sexualidade e raça na prática política investigada. Assumindo o método qualitativo de pesquisa, esta investigação de cunho etnográfico utilizou-se de entrevistas semiestruturadas realizadas junto às hip hoppers, bem como da observação participante oriunda da convivência junto ao grupo estudado, sob o aporte interdisciplinar dos estudos de gênero e feministas.

Sou grata pela aprovação da dissertação de mestrado "Hip-hop feminista? Convenções de gênero e feminismos no movimento Hip-hop soteropolitano" para publicação no Concurso de teses e dissertações do Programa de Pós-Graduação em Estudos Interdisciplinares sobre Mulheres Gênero e Feminismo (PPGNEIM) para a Coleção Bahianas/Edufba, neste momento de comemoração dos dez anos do PPGNEIM, como parte das ações do Projeto de Incentivo à Produção Acadêmica na área dos Estudos de Gênero Feminismo, desenvolvido com recursos da PROPG/ UFBA (Pro-Consolidar 2012), como uma das produções científicas que fazem o diferencial do Programa e de suas pesquisas, nesta 
oportunidade em que apresenta jovens pesquisadoras em estudos feministas e de gênero na Bahia e Brasil.

Gostaria de expressar aqui gratidão a todas as mulheres que me apoiaram nessa caminhada com amizade e solidariedade. Em especial, à querida Zelinda Barros, por sua imprescindível tutoria e parceria no meu processo de formação pessoal e acadêmica feminista decolonial, bem como nos primeiros passos desta pesquisa e de suas trocas.

Sou grata ao movimento Hip-hop, e às hip hoppers parceiras da pesquisa, Carla Cristina de Jesus Santos (Kaia na Paz), Simone Gonçalves Santos (Negramone), Ana Paula Conceição Oliveira (Azeviche), Eliciana Santos Nascimento (Lis), Priscila Nayala da Costa Lino (in memoriam), Vivian Quatuni (Olhasse), Dina Lopes, Mônica Reis (Índia), em especial à Rede Aiyê Hip-Hop, à banda Munegrale e ao grupo Hip-Hop Coisa de Menina. Vocês são a principal inspiração deste trabalho, parabéns e gratidão. Em especial, a Jorge Hilton que me apresentou o hip-hop baiano e me convidou para as atividades, a Gilmara de Lima Souza (Mara Assatawaa), aos amigos da querida banda Fúria Consciente, e a todxs xs amigxs, colegas e artistas de quem sou fã.

Agradeço a todas as minhas professoras, em especial à minha orientadora, professora Alinne de Lima Bonetti, pela dedicação a seu ofício, com lições imprescindíveis para a vida de uma jovem pesquisadora. À professora Ana Alice Alcantara Costa, que me orientou na iniciação científica, com sua formação nos estudos feministas e em ciência política e me apresentou ao feminismo. Ao querido professor Jorge Almeida, pelo incentivo à pesquisa. Ao professor Cloves Luiz Oliveira, querido tutor acadêmico que acreditou nesta proposta de pesquisa no bacharelado em Ciência Política pelo apoio e trocas científicas em sua orientação sobre o tema.

Sou grata fundamentalmente as imprescindíveis parceiras, à querida professora Márcia Santana Tavares, fundamental 
incentivadora desta publicação e nome do Núcleo de Estudos Interdisciplinares sobre a Mulher (NEIM), e à professora Flávia Goulart Roza, Eliene de Jesus, Angela Garcia Rosa e Susane Barros em nome da nossa Edufba, que se mobilizaram para concretizar a publicação deste livro. Essa publicação não seria possível sem vocês. A Mônica Reis e Jackson Barbosa (Pinel) pelas fotos dos grafites.

Às queridas professoras Paula Cristina Barreto e ao Programa A Cor da Bahia, pelo início desta pesquisa na graduação sanduíche na Vanderbilt University com a professora Kathyne Gines e o "Hip Hop and Black Sexual Politics”. À Capes/FIPSE pelo financiamento que possibilitou o contato com uma experiência de cooperação internacional coordenada pelos professores Jane Landers e Marshall Eakin.

À Capes, pelo imprescindível financiamento desta pesquisa durante o curso de mestrado e no Programa de intercâmbio acadêmico em Florianópolis (PROCAD) em visita ao Programa de Pós-graduação em Ciências Humanas da Universidade Federal de Santa Catarina (UFSC), às professoras e colegas do Sul, e, em especial, à família de Gleidismara dos Santos Cardozo. À querida professora Angela Maria de Souza, que me recebeu no Sul, pelo orgulho de ter seu prefácio no meu primeiro livro, compartilhando o Hip-hop latino-americano e os feminismos negros. À professora Tanya Sanders que escreve o posfácio desse livro.

Grata a todxs as colegas, em nome de Gilberta Soares, imprescindível em suas articulações científicas e acadêmicas, à fotógrafa Renata Nascimento, bem como às leitoras e leitores desta obra. À minha família, minha avó Geraldina Sobral, incentivadora desde sempre, minha mãe Socorro (in memorian) e à tia Solange, a Rose Silva Dendê Curry, a Ivana Chastinet (in memorian) e a Sintia Araújo. A Carlo Wallnöfer e família pelo jardim na moradia do bairro dos Aflitos, studio desta obra. Ao meu companheiro André Luiz Rodrigues Costa e família, e ao Esclitória Studio. Gratidão! 


\section{SUMÁRIO}

13 PREFÁcio - ANGEla Maria de SouZA

21 APRESENTAÇÃo - MÁRCIA TAVARES

\section{ชิธง}

25 APROXIMANDO OS CAMPOS:

gênero e Hip-hop

43 O HIP-HOP NÃO PARA!

77 HIP-HOP É TAMBÉM COISA DE MENINA? convenções de gênero e mulheres jovens no movimento hip hop soteropolitano

129 HIP-HOP:

espaço de contestação das convenções de gênero?

163 AGORA OS MENINOS PRECISAM SABER QUE COISA DE MENINA TAMBÉM É COISA DE MENINO! HIP-HOP FEMINISTA?

191 REFERÊNCIAS

199 POSFÁCIO - RUMO À PRÁXIS DE UM HIP-HOP BRASILEIRO FEMINISTA:

uma introdução

211 GLOSSÁRIO

vocabulário do universo hip-hop 


\section{PREFÁCIO}

Angela Maria de Souza ${ }^{1}$

Realizar uma pesquisa sobre o movimento Hip-hop nos suscita inúmeros debates e proposições. Se esse Movimento é realizado por mulheres, a discussão só se amplia. Esse é um dos aspectos que quero ressaltar neste trabalho, as problematizações e provocações que nos proporciona e que nos fazem refletir sobre as pautas e demandas levantadas por essas mulheres na cidade de Salvador.

Se voltarmos nosso olhar para os anos de 1990, quando começaram as primeiras pesquisas sobre o movimento Hip-hop, podemos perceber mudanças bastante significativas com relação à ampliação desta temática nas mais diversas áreas do conhecimento. Porém, essa ampliação não significa grandes aberturas acadêmicas para o debate sobre o próprio movimento Hip-hop e o que ele se propõe, ao contrário, as barreiras persistem. Mas no caso deste estudo quero problematizar essa questão a partir da relação e do pertencimento estabelecido entre as interlocutoras

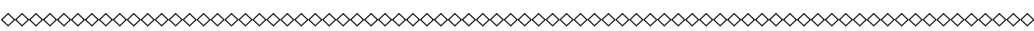

1 Docente do Programa de Pós Graduação Interdisciplinar em Estudos Latino Americanos - PPG IELA, do Curso de Antropologia e Pró-Reitora de Extensão na Universidade Federal da Integração Latino Americana (UNILA). Coordenadora do Núcleo de Estudos Afro-Latino Americanos (NEALA). 
da pesquisa, o que muda de forma determinante o olhar e o fazer acadêmico sobre temáticas como o movimento Hip-hop.

Mulheres Negras são as condutoras desta obra, tanto quem a escreve, Rebeca Sobral Freire, como a partir do olhar que ela direciona e na forma como estabelece a interlocução com outras mulheres que estão dentro do movimento Hip-hop em Salvador. Rebeca nos mostra duas combinações pouco visibilizadas, mulheres no movimento Hip-hop e suas práticas a partir da cidade de Salvador-Bahia, conhecida por tantos outros estilos musicais, o que faz total diferença na produção de um movimento Hip-hop feminista ou feito por mulheres, bem como na realização deste trabalho.

Com uma perspectiva interseccional, este trabalho nos traz um debate fundamental a partir de uma tripla perspectiva, de gênero, de raça e de classe que perpassa o universo de mulheres do movimento Hip-hop soteropolitano e nele acrescenta a questão da juventude como determinante para o direcionamento deste olhar.

Além da interseccionalidade, tal etnografia é produzida a partir do envolvimento da pesquisadora na sua forma de atuação neste espaço de luta e debate político. Além do consistente envolvimento acadêmico, esta pesquisa é resultado de um envolvimento político que faz total diferença na relação estabelecida com as mulheres do movimento Hip-hop. Mesmo essa relação sendo bastante questionada na academia, e muitas vezes chamada pejorativamente de militância, não há como pensar numa perspectiva estritamente acadêmica, já que, enquanto mulheres negras, jovens, oriundas das classes populares, nossas pesquisas são perpassadas, transpassadas, e se estabelecem nessa relação no trabalho de campo, como podemos perceber nesta pesquisa engajada que aqui se apresenta e que torna-se um diferencial estruturante deste trabalho. 
As trajetórias das mulheres do movimento Hip-hop não são trajetórias tão distantes do universo da pesquisadora. O envolvimento e o comprometimento vão muito além do meramente acadêmico e entrecruzam-se como trajetórias de vida que marcam estas páginas escritas e apresentadas como pesquisa; e este é um movimento epistemológico determinante para repensarmos as bases em que se sustentam os conhecimentos acadêmicos, ou seja, para problematizá-los. O conhecimento não é desinteressado, mas precisamos saber e definir o que significam esses interesses e como são utilizados nos espaços acadêmicos, que são também espaços de poder, espaços definidos por práticas racializadas e masculinizadas. Problematizar esses espaços é problematizar as formas como são ocupados e isso significa ter uma atuação política dentro dos espaços acadêmicos. Posicionamentos militantes e acadêmicos se cruzam, são posicionamentos políticos.

Ao entrarmos nas universidades nossos corpos falam, informam quem somos, Mulheres Negras. Somente isso seria suficiente para termos uma postura política perante as forças que nos afetam ou nos mobilizam, e situo, entre essas, as escolhas que realizamos para construir nossas trajetórias acadêmicas, nas quais estão as temáticas e abordagens das pesquisas que realizamos. Tudo isso informa sobre nossos posicionamentos políticos nos espaços acadêmicos.

No caso desta pesquisa, não temos como não ressaltar que dentro do movimento Hip-hop as mulheres negras vêm gerando provocações que o redefinem. Se há uma renovação do movimento Hip-hop atual, essa vem se dando em função das posturas, posicionamentos e produção artístico-cultural dessas mulheres no Movimento. Suas pautas, suas trajetórias e suas demandas dinamizam o movimento Hip-hop e os homens precisam se posicionar, inclusive com relação aos espaços que ocupam. Essas mulheres geram mudanças nesses espaços e só por isso já deveriam 
ser consideradas feministas, mas elas representam muito mais, representam uma trajetória que é invisibilizada, a história das Mulheres Negras, a qual mais do que feminista é revolucionária, é a própria história da resistência. Quando Eliciana nos diz que [...] uma coisa que eu sempre ouço é que enquanto as mulheres brancas estavam queimando sutiã, as mulheres negras estavam incendiando fazendas! Ela ressalta a forma de posicionamento dessas mulheres. Guardadas as devidas proporções entre as épocas e movimentos históricos, ela nos faz perceber que para nós, mulheres negras, lutar por direitos, igualdade e cidadania é nossa história, é a própria resistência que nos faz persistir. Na história, nunca tivemos a opção de não lutar, afinal de contas, da luta dependemos para a própria existência.

A luta da Mulher Negra é permanente contra o patriarcado escravocrata que vivenciam cotidianamente. E essa prática patriarcal racista pode ser lida através dos dados estatísticos (IPEA, 2017) ${ }^{2}$ sobre os alarmantes índices de morte da juventude negra $(71 \%)$. Ou, na violência contra a mulher negra, que apesar das políticas públicas e da própria Lei Maria da Penha, aumentou e passou de 54,8 (2005) para $65,3 \%$ (2015). A Mulher Negra e a juventude são as principais vertentes que delineiam as pautas das mulheres do movimento Hip-hop, e suas experiências de vida são os espaços em que essas demandas surgem e são politizadas.

Esse cenário reflete o reforço de uma politização do movimento Hip-hop, muitas vezes comprometida quando alguns desses jovens são seduzidos por práticas midiáticas e comerciais. São essas mulheres que retomam e renovam a discussão que fortalece o movimento Hip-hop como espaço de luta e contestação, principalmente tendo suas trajetórias de vida como condutoras

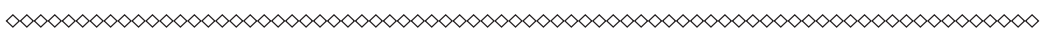
2 Instituto de Pesquisa Econômica Aplicada (IPEA) e Fórum Brasileiro de Segurança Pública (FBSP). Atlas da Violência 2017. Rio de Janeiro, 2017. 
de suas práticas militantes e políticas. Para essas mulheres, discurso e prática são constituintes da mesma ação.

Gostaria de ressaltar aqui outro aspecto que considero relevante neste trabalho. Se vários trabalhos sobre o movimento Hip-hop se relacionam a gênero pela análise das letras de rap e por usarem referências do Rap das Mulheres do contexto nacional, este trabalho nos apresenta uma etnografia realizada entre jovens mulheres que produzem rap numa perspectiva interseccional. As mulheres do movimento Hip-hop soteropolitano possibilitam aprofundar um debate, ainda hoje, pouco considerado nos espaços acadêmicos, ou seja, ainda são perspectivas percebidas como pouco relevantes dentro da academia e que realizá-lo implica num posicionamento político dentro das universidades. Este trabalho, através das vozes das mulheres do movimento Hip-hop de Salvador, a partir de suas perspectivas e posicionamentos políticos e militantes, busca ampliar a cidadania das mulheres em todos os seus aspectos, mas, especialmente, no que se refere aos direitos das Mulheres Negras.

Mesmo o movimento Hip-hop ainda sendo um espaço de maioria masculina, essas mulheres não "descobrem brechas", elas conquistam espaços a partir de suas pautas e de suas posturas. Renovam o movimento Hip-hop com pautas criadas a partir de suas vivências e experiências enquanto jovens mulheres negras, enquanto sujeitos políticos, assim como a autora desta obra. Nesse posicionamento segue o desafio de fazer do movimento Hip-hop um movimento social nas práticas da diáspora afro-latino-americana.

O movimento Hip-hop das mulheres negras gera uma renovação das lutas políticas dos movimentos negro, feminista, da juventude, de periferia, artístico-cultural e de muitos outros que, a partir de suas práticas e intervenções, possibilitam uma 
ampliação do debate político numa perspectiva local-transnacional que é constituinte de suas práticas, como nos coloca Negramone:

Esse feminista local a gente pode se dizer que a gente, enquanto juventude, enquanto mulheres, ele existe, mas [...] entendendo as suas diversidades, entendendo [...] como a gente quer o feminismo. Não é universal, é como o Hip Hop. O movimento Hip Hop não é universal dentro de uma política de justiça social, racial. Ele existe em suas diversidades, ele tem as suas outras vertentes de filosofia assim como o feminismo, entendeu? Por isso que gente vai direcionando pra aquele feminismo local, aquele movimento local, mas dialogando com essa diversidade nacional e internacional e entendendo essa diversidade.

Essa fala nos remete a uma das bases do movimento Hip-hop, a qual prescinde de um contexto local para sua formação, constituição e luta, porém em diálogo permanente com os espaços internacionais e as políticas transnacionais sobre as temáticas e pautas que os afetam. E o mesmo elas fazem com o feminismo, pois as pautas específicas são constituintes das práticas do movimento Hip-hop das mulheres negras, assim como se conectam com contextos muito mais amplos, que unem lutas e com isso renovam as práticas do feminismo. Esse é um feminismo negro que parte das práticas e ações do movimento Hip-hop e vice-versa, como espaço de luta política. A maneira como essas jovens se apropriam e produzem o movimento Hip-hop dá forma a suas lutas políticas de jovens mulheres negras, ou seja, de uma perspectiva interseccional.

Retomando uma questão fundamental do trabalho, a tripla articulação entre movimento Feminista, movimento Negro e movimento da Juventude, é necessário destacar que esse posicionamento 
parte da vivência dessas mulheres a partir de suas trajetórias pessoais e históricas. Assim como inúmeras mulheres negras, a luta é permanente e cotidiana e essas lutas passam a entrar no contexto acadêmico quando pesquisadoras são também mulheres negras. Essa interlocução é determinante para pensarmos trajetórias políticas, acadêmicas e militantes que se cruzam e fazem parte de uma mesma trajetória de vida.

Esta pesquisa nos permite vislumbrar potencialidades de renovação de movimentos políticos e artístico-culturais determinantes na luta pela cidadania, pautada no respeito à diferença, seja no movimento feminista, no movimento Hip-hop, no movimento negro ou nos movimentos das juventudes. Em todos esses reside um pertencimento que fortalece as lutas e que faz da trajetória dessas mulheres direcionadoras de visibilidades e conquistas cada vez mais urgentes, especialmente no atual momento político. 


\section{APRESENTAÇÃO}

A Coleção Bahianas, desde sua primeira edição, em 1997, mostrou-se desafiadora e, passados quase 20 anos, mantém-se como espaço de socialização de estudos teóricos e empíricos. Esses estudos buscam questionar as convenções e estereótipos de gênero que, fundadas em uma lógica ainda binária, inscrevem lugares e posições distintas para mulheres e homens. No cenário contemporâneo, essas posições se intensificam ainda mais quando enfeixadas a outras categorias como raça, classe social, geração e/ ou território em que se deslocam e interagem.

Do mesmo modo, tem compartilhado as questões que instigam o pensamento feminista, seja no que se refere ao colocar sob suspeita a lógica cartesiana que rege a produção de conhecimento e propor uma revisão crítica das bases da ciência contemporânea, superando a polaridade entre sujeito e objeto, de modo a incorporar a diversidade (PASSOS, 1997), seja ao se constituir em espaço de diálogo para novas pesquisadoras que adotam em seus estudos uma perspectiva de gênero e feminista para cartografar novos feminismos, a partir da criação do Programa de 
Pós-Graduação em Estudos Interdisciplinares sobre Mulheres, Gênero e Feminismo (PPGNEIM).

Com efeito, desde 2008, a Coleção Bahianas tem trazido edições sob a forma de coletâneas, contendo artigos que resultam de dissertações defendidas no Programa ou que ilustram a diversidade teórico-metodológica presente na dinâmica multidisciplinar que define a produção acadêmica do PPGNEIM. (COSTA, 2011)

Em 2012, sob a coordenação da professora Ana Alice Alcantara Costa, o PPGNEIM lançou uma chamada interna relativa ao processo seletivo para a publicação de trabalhos de conclusão (teses e dissertações) do referido programa, cujos projetos selecionados seriam publicados pela Editora da Universidade Federal da Bahia (Edufba) através da Coleção Bahianas, como parte das ações do Projeto de Incentivo à Produção Acadêmica na área dos Estudos de Gênero e Feminismo, a ser implementado com recursos oriundos da PROPG/UFBA (Pro-Consolidar 2012).

Dentre os trabalhos selecionados, tenho o prazer de apresentar o livro Hip-hop feminista? Convenções de gênero e feminismos no movimento Hip-hop soteropolitano, no qual a autora Rebeca Sobral Freire, a partir de inquietações acerca da atuação de jovens mulheres no movimento social Hip-hop, perscruta como se configuram "as convenções de gênero e feminismos" nesse movimento em Salvador. Nesse estudo, a autora analisa a existência de um hip-hop feminista jovem, negro, soteropolitano, a partir da perspectiva das mulheres inseridas nesse movimento, e interessa-se em compreender quais são suas concepções acerca do feminismo (ou o feminino), investigando se há e de que forma influenciam as experiências dessas mulheres diante de um contexto que dialoga com a cultura política local vigente.

Tal como suas interlocutoras, Rebeca Sobral é uma jovem feminista cuja curiosidade intelectual e abordagem sensível se refletem em um texto ágil, instigante e inovador, que atenta ao 
entrelace de marcadores sociais de diferença (gênero, geração, raça, sexualidade e classe social) e convida-nos a conhecer jovens feministas em movimento, como as hip hoppers, suas reflexões e discursos feministas, suas formas de engajamento e participação política, bem como os desafios enfrentados para consolidar um hip-hop feminista que, como ressalta a própria autora, contesta o feminismo de origem branca e europeia, no qual as hip hoppers não se reconhecem, (re)significando-o com base em suas próprias experiências de mulheres negras, pobres e trabalhadoras.

O feminismo muda constantemente, em resposta a cada nova demanda e a cada conquista, como reflete Ana Alice Costa, mas como ela mesma coloca, no movimento Feminista a dialética viaja na velocidade da luz, e é impossível para aquelas (eles) que não vivenciam suas entranhas captar essa dinamicidade. Neste sentido, o livro de Rebeca Sobral pode ajudar o(a) leitor(a) a compreender a forma como os novos feminismos se reinventam a partir da prática e reflexão das jovens feministas hip hoppers, e a vislumbrar as possibilidades feministas em sua luta para existirem em igualdade com os homens no hip-hop e na vida. Por isso, ao comemorarmos os dez anos de existência do PPGNEIM, consideramos oportuna a publicação deste livro de Rebeca Sobral, versão da sua dissertação de mestrado que nos permite socializar com um público mais amplo a produção acadêmica de uma geração de jovens pesquisadoras e, tanto ilustra o processo de formação do corpo discente de nosso Programa, como revela os caminhos percorridos e direcionamentos dos novos feminismos.

Boa leitura! Márcia Tavares 


\section{APROXIMANDO OS CAMPOS: gênero e Hip-hop}

A experiência de um estudo sobre as mulheres no hip-hop, desde o início, foi considerada um desafio a ser enfrentado, respectivamente, nos campos da Ciência Política e dos Estudos Interdisciplinares de Gênero e Feminismos. Ao fundamentar essa proposta na teoria feminista permitiu-se romper com uma concepção restrita do que seria "político"3 e adotar uma visão ampla, que abarca o diálogo entre a política e a cultura. Assim, ocorreu o mapeamento do diálogo entre perspectivas diversas de conhecimento que compartilharam o interesse sobre a relação gênero e hip-hop.

Originado nos Estados Unidos, ${ }^{4}$ na década de 1970, o Hip-hop caracteriza-se como um movimento político e cultural constituído sob a influência de dois importantes movimentos ocorridos no mesmo país. O primeiro, o Movimento dos Direitos Civis, ocorrido

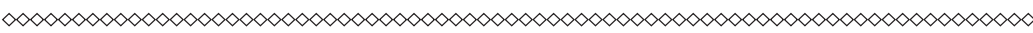

3 Inicialmente vinculado a uma interpretação institucionalizada, mais ligada ao campo do formal da "política", a exemplo de partidos, eleições, cargos representativos, mandatos, políticas públicas etc.

4 É usado o termo "estadunidense" para o que for oriundo dos Estados Unidos, em oposição ao termo "americano", que mantém a perspectiva colonizadora em relação ao continente; sendo usado "americano" para todos os países do continente. 
nas décadas anteriores, liderados por Rose Parks e Martin Luther King Jr. e, o segundo, inspirado pelo movimento Black Power, referendado por Angela Davis e o grupo Panteras negras.

Ambos os movimentos precursores do hip-hop compartilhavam, respectivamente, pautas de combate às desigualdades sociais, mais especificamente direcionadas para as questões de cunho racial. De acordo com Patrícia Hill Collins (2006), a ascensão do hip-hop representa o período pós-movimentos por direitos civis e é marcada pelo fim do movimento Black Power, surgindo como uma alternativa à cegueira sobre o mito do fim do racismo no país ${ }^{5}$ e da promoção do "sonho americano" de iguais oportunidades para todas as pessoas; ainda, a "guetização" (ghettoization) dos pobres e da classe trabalhadora negra e jovem estadunidense.

A mídia americana criou e transmitiu comercialmente o Hip-hop como uma espécie de "cultura negra americana" (black american culture), vinculado à pobreza, às drogas, à violência e à hipersexualização dos corpos negros, especialmente das mulheres negras. Collins (2006) explica que essa propaganda publicizou o estilo fashion da negritude a partir dos elementos do hip-hop, transformando-o em uma indústria de milhões de dólares. Assim, o Hip-hop, em seus vários aspectos, tornou-se alvo de interesse de estudos das Ciências Sociais. A autora aponta que a geração jovem, formada por adolescentes e recentes jovens adultos nascidos após as conquistas da Era dos movimentos por direitos civis (integração racial) e dos processos de crises econômicas nos Estados Unidos, independente de classe social, gênero, raça ou etnia, ou orientação sexual, compartilha esse período como uma etapa de politização da vida social.

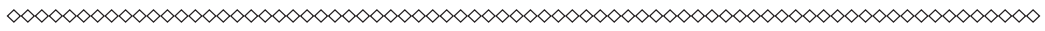

5 Sobretudo pelo lado institucional que marca o fim das leis de segregação racial nos Estados Unidos que apartavam a população branca e negra.

6 Entendo "gueto" como referência a um espaço restrito à convivência entre determinado grupo étnico e classe pobre, que passa a determinar estilo e condições de vida diante da exclusão social. 
Vale ressaltar que as conquistas alcançadas pelos movimentos por direitos civis dos Estados Unidos ecoaram pelo mundo e influenciaram movimentos de luta por cidadania de outros países. Como esta juventude do "Black Power para o Hip Hop" (COLLINS, 2006) teria voz para questionar os problemas que enfrentam em seu cotidiano, a ponto de inspirar e compartilhar experiências de desigualdades e estratégias de superação das mesmas, estando em lugares tão distantes?

O Hip-hop, como um movimento de juventude, se expandiu pelo mundo a partir de seus quatro elementos artísticos: 1) Break, ${ }^{7}$ é a dança de rua; 2) Grafite, ${ }^{8}$ é a expressão das artes plásticas nos muros da cidade; 3) Rap, ${ }^{9}$ é a música, sendo o $D J^{10}$ o responsável pelo beat - a batida. Apenas quando unidas essas expressões constituem o hip-hop, ao promoverem em uma articulação entre cultura e política. Há que se considerar um "quinto elemento" que permeia seus elementos clássicos: a politização que motiva a participação juvenil individual e coletiva em questões relevantes ao seu cotidiano e suas identidades, muitas vezes identificadas pelos jovens do movimento por "militância".

Na década de 1980, o Hip-hop chega as principais capitais brasileiras, São Paulo e Rio de Janeiro, inserido num contexto de problemas sociais que acometem a população periférica. Sua cultura e

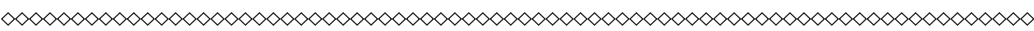

7 A mulher que dança break, em seus vários estilos, é chamada de $b$-girl e o homem de $b$-boy.

8 A mulher que grafita, em seus vários estilos, é chamada de grafiteira e o homem de grafiteiro, pois trabalham basicamente os sprays para grafitar, desenhar utilizando a técnica do spray. Uma questão importante é a distinção entre a grafitag’em e a pichação, sendo a primeira considerada uma arte urbana que se inicia nos muros da cidade e depois adentra inclusive em galerias de arte, expondo questões do cotidiano urbano e questões vigentes da sociedade, enquanto a pichação é reconhecida como uma poluição visual e violação urbana com o intuito apenas de depreciar os espaços das cidades.

9 A mulher ou homem que cantam rap em seus vários estilos compartilham o nome de rapper ou Mc (Mestre de cerimônia).

10 A mulher que toca na pick-up (equipamentos eletrônicos que tocam diversos discos de vinil de diferentes estilos musicais, criando samples - recortes de batidas musicais diversas - também em seus vários estilos, atualmente também se utilizando de computadores e programas de áudio para edição destas novas batidas) é chamada de Djeia e o homem de DJ. 
estética de afirmação da identidade negra agitaram os bailes black, iniciados pelo funk, festas dançantes que priorizam estilos musicais a partir de bandas e artistas negros nacionais e internacionais, a exemplo de James Brown e Jorge Ben Jor. Evento comum nas periferias, esses bailes estimularam um cenário de danças, vestimentas e variados penteados para os cabelos crespos, através dos quais se destacava o chamado estilo black power, desafiando a imposição de um modelo de beleza vinculado à "branquitude".

Nesse período, na cidade de Salvador, acontecia o baile Black Bahia, no bairro periférico Periperi, do qual participavam grupos de dança de funk, a exemplo dos grupos Cobra funk (apenas meninos) e Cobra funk girls (meninas a partir de dez anos), que apresentavam as primeiras expressões do hip-hop com dança e música. Em 1996, as primeiras expressões do hip-hop se uniram para a formação de seu primeiro grupo, a Posse Ori, quando se concretiza a formação do hip-hop como um movimento social.

De acordo com Aldenora Lima (2006, p. 13), as posses podem ser entendidas como “[...] um núcleo de atuação e reflexão do movimento Hip-hop, local onde ocorrem reuniões semanais e são discutidos os projetos futuros e divulgados eventos e festas". Priscila Matsunaga (2008) atualiza um novo termo para esses grupos, também chamados de crew, tendo uma conotação específica para grupos de dança e/ou de grafite. Ambas autoras concordam que, a partir de suas manifestações artísticas, mulheres e homens jovens do hip- hop passam a interpretar politicamente a sua própria cidadania.

Além dos trabalhos artísticos realizados em torno dos elementos do hip-hop, as posses promovem atividades nas comunidades, que assumem diversos formatos, como palestras em escolas e faculdades (WELLER, 2000) e participação em mesas de debate em seminários, congressos e aberturas de encontros de diferentes temáticas sociais, em especial com foco racial e de 
juventude. Foi a partir das "posses” que o hip-hop soteropolitano congregou jovens de um mesmo bairro ou região, os quais desenvolviam os elementos que caracterizam o movimento e atuavam politicamente em torno de demandas de sua comunidade e de problemas que afligiam seu cotidiano.

A partir da inserção nas posses e grupos de hip-hop (a exemplo das bandas de rap), muitos jovens puderam sair de seus bairros de origem localizados na periferia - em sua maioria distantes do centro histórico e tradicional da cidade - para circularem por outros bairros, incluindo o centro. ${ }^{11}$ Essa oportunidade lhes permitiu não apenas a criação de novas rotas, de deslocamentos, mas também adentrar em espaços políticos e históricos da cidade, conhecer pessoas e participar de outras atividades culturais e políticas, que abordavam temas diversos.

Hoje o hip-hop pode ser encontrado nas grandes capitais de todo o mundo e também nas cidades do interior de diferentes estados e países. As cidades, em especial os grandes centros urbanos, são os maiores cenários de propagação do hip-hop e seus elementos, considerando sua evidência prioritariamente em contextos de desenvolvimento, migrações e, sobretudo, intensas desigualdades sociais. (BILL, 2005)

Na Bahia, estado nordestino que reúne um dos maiores contingentes de negros, marcado por grandes disparidades no que se refere à distribuição de renda, esse movimento destaca o aspecto racial como extremamente relevante para o reconhecimento de sua identidade pessoal e de grupo. Além disso, a crescente afirmação da presença das mulheres, como constatada nesta

11 Muitas vezes, esses jovens frequentavam lugares e circuitos urbanos a que seus pais, mães e familiares ainda não tinham ido, por restringirem sua circulação à região dos bairros onde moram, ou mesmo dirigindo-se ao centro apenas esporadicamente ou raramente quando vinculados a algum trabalho, necessidades médicas ou burocráticas, não exatamente conhecendo e frequentando lugares de lazer gratuitos como praças, teatros e o próprio Centro Histórico do Pelourinho (Diário de Campo, Reunião "Curso de formação de b-girls", abril 2008). 
pesquisa, destaca aspectos relevantes da configuração do recente movimento Hip-hop soteropolitano.

Para tanto, é dada a prioridade, neste momento, à contextualização do contato com o universo da pesquisa. Embora já fosse difundido socialmente o elemento musical do hip-hop, o rap, nos anos 2000 o hip-hop se destaca fortemente como movimento social em Salvador. O interesse de investigação sobre o tema se deu a partir de uma rica experiência junto ao hip-hop no III Encontro de Gênero e Hip-Hop, no ano de 2005, em Lauro de Freitas. (FREIRE, 2010) Essa atividade destacou o potencial do hip-hop como tema e objeto de estudo, sobretudo pela crescente participação das mulheres que afirmavam sua pauta na agenda do movimento.

No geral, aquele cenário propiciava o levantamento de uma série de problemáticas envolvendo a preocupação com a cidadania da juventude negra baiana, e, em especial, da periferia. Essa preocupação estava diretamente relacionada não apenas à luta por direitos, mas também em objetivar prioritariamente naquele espaço a discussão sobre as relações (de gênero) entre homens e mulheres, homens e homens, e mulheres e mulheres e sobre o contexto de reprodução da hegemonia masculina dentro do próprio movimento e suas implicações no cotidiano e na própria militância de seus integrantes.

O que chamou atenção foi o fato de terem sido as próprias mulheres as produtoras daquele espaço de discussão e que priorizaram, na programação do evento, a participação dos homens em seu segundo dia. Essa é uma experiência inédita ou, no mínimo, inovadora, diante das experiências de outros grupos e segmentos políticos mistos de movimentos sociais vigentes na época. Outros dois aspectos relevantes são a autoidentificação deste segmento como jovem e seu envolvimento com questões em torno do feminismo. 
A partir dessa experiência, foi perceptível a rentabilidade analítica que o estudo do movimento Hip-hop, de característica jovem, feminista e negra, traria para diferentes campos de estudo, simultaneamente. Já que, de um lado, questiona a hegemonia do sujeito homem de análise dos estudos da política e, de outro, desafia a predominância das mulheres adultas como foco dos estudos feministas e de gênero. (FREIRE, 2010) Além disso, essa experiência inclui os elementos dos campos de estudo sobre identidade, vinculados às relações étnico-raciais e de idade/geração, ambas desprivilegiadas nos estudos de gênero e da política.

No que se refere à participação das mulheres jovens, com o foco sob o aspecto geracional, assumem um caráter distinto em relação às mulheres adultas, havendo uma lacuna em relação à sua participação em manifestações político-culturais. (WELLER, 2005) No caso da participação das mulheres e de outros sujeitos subalternizados, é fundamental seu resgate histórico devido à necessidade de se compreender a importância dos registros da realidade histórica no passado, sua repercussão no presente e suas possibilidades para o futuro.

Nesse caso, a ausência e pouca visibilidade das mulheres também são constatadas nos estudos sobre hip-hop, nos quais se encontra uma predominância masculina em sua representação (MARTINS, 2004; MIRANDA, 2006; MORAES NETO, 2006; OLIVEIRA, 2007), e/ou quando a participação das mulheres não é compreendida a partir de uma perspectiva feminista de gênero. No entanto, no Brasil tem se expandido, nos últimos anos, uma produção científica interessada nas experiências da juventude, vinculadas ao movimento Hip-hop em contato com gênero e feminismo, estabelecidas entre mulheres e homens, e mulheres e mulheres, no espaço do movimento e em seus elementos culturais e artísticos. 
A maioria desses estudos estão voltados para apenas um único elemento do hip-hop como objeto de pesquisa, o rap. Para tanto, serão apresentados alguns dos trabalhos que exemplificam essa exclusividade de olhares para este elemento, muitas vezes também chamado pelo próprio nome "hip-hop" pelo público geral ou devido ao senso comum em torno desse estilo musical. ${ }^{12}$

É o que mostra o trabalho sobre as performances das integrantes de bandas femininas de distintos estilos musicais da região de Florianópolis (SC), de Rodrigo Gomes (2008). Entre cinco bandas pesquisadas, uma delas é identificada com o estilo hip-hop, chamada "Declínio do Sistema”, o que evidencia a participação das mulheres no elemento musical do hip-hop. De acordo com o autor, a partir da performance das rappers:

Percebemos que as mulheres, em especial mulheres negras, estão encontrando um significativo espaço para fomentar discussões sobre as causas femininas, provendo através das letras das canções a conscientização das mulheres sobre os temas como aborto, cuidado com o corpo, uso de anticoncepcionais. Este também é um lócus para a divulgação dos seus direitos civis, como, por exemplo, licença maternidade, aposentadoria para donas de casa e domésticas, denúncia à violência contra mulheres, etc. (GOMES, 2008, p. 144)

Além disso, Gomes (2008) salienta a necessidade de mais estudos sobre a crescente participação das mulheres no meio musical, como produtoras e consumidoras dessa arte em desenvolvimento no país. No campo da arte, a música representa um espaço privilegiado para analisar a sociedade, seja através das personalidades atuantes e suas expressões artísticas diversas, sejam musicais, teatrais, dança ou artes plásticas. Entretanto,

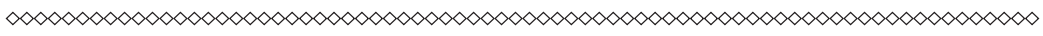

12 De natureza autoral em sua maioria, as letras e músicas de rap são escritas e interpretadas pelos próprios compositores e compositoras rappers. Para compor o repertório da banda, pode-se encontrar grupos de rap que possuem composições em grupo/coletivas ou que compartilham uma letra de autoria de apenas um de seus integrantes. 
o autor não se propõe a avaliar a relação das bandas com grupos do movimento de mulheres ou mesmo com posses do hip-hop.

Priscila Matsunaga (2008) também aborda as representações sociais das mulheres no movimento Hip-hop através do rap. Ela analisa 32 letras de rap de homens e mulheres, sendo produções originadas de Piracicaba e São Paulo, e constata a existência de três papéis femininos: mãe/namorada, negra batalhadora e objeto vulgar. Nesse contexto, é possível perceber o posicionamento de algumas rappers, identificadas como feministas pela autora, devido à resistência a se converterem ao discurso dominante de hierarquização entre homens (acima) e mulheres (abaixo), que orienta comportamentos preestabelecidos por sexo também no hip-hop, além da busca por ampliação dos espaços de debate sobre suas demandas políticas. Entretanto, a autora não avança em questionar posições relacionadas a uma identidade feminina ou feminista pelas hip hoppers.

"Há feministas no Hip-Hop, mesmo diante do cenário de predominância masculina?”. (SILVA, 1995) Essa é uma pergunta relevante e compartilhada de interesse neste livro. Segundo "O rap das meninas", de Maria Aparecida da Silva, as mulheres do hip-hop estavam presentes nos mais importantes encontros feministas, nacionais e internacionais, inclusive na Conferência de Beijing, ${ }^{13}$ e tiveram relevante papel de articulação e fortalecimento do movimento de mulheres e feminista brasileiro e latino-americano.

A autora justifica que "[...] estas garotas tem a manha, a artimanha, a malemolência de um samba miudinho para se movimentarem em espaços predominantemente masculinos" (SILVA, 1995, p. 516), e também para adentrar em espaços considerados exclusivos às mulheres adultas. Afirma, ainda, que assumidas

$\infty<\infty<\infty<\infty<\infty<\infty<\infty<\infty<\infty<\infty<\infty<\infty<\infty<\infty<\infty<\infty<\infty<\infty<\infty<\infty<\infty<\infty<\infty<\infty<\infty<\infty<\infty<\infty<\infty<\infty<\infty$

13 A Conferência de Beijing, como ficou conhecida a IV Conferência Mundial Sobre as Mulheres, que aconteceu na capital da China, Beijing, no ano de 1995, reuniu delegações governamentais e organizações não governamentais de diversos países para discutirem questões relacionadas às mulheres. 
como feministas ou não, sem rótulos, as rappers paulistanas que se autoidentificaram como negras mostraram consciência das desigualdades de gênero, raça e geração a serem superadas. Estas afirmaram utilizar o rap como um desabafo para suas questões e como um meio para serem ouvidas. Contudo, a pesquisa de Silva aponta que não há uma preocupação das interlocutoras em se afirmarem feministas ou não, não chegando a aprofundar o entendimento acerca das concepções sobre o feminismo pelas mesmas e seus argumentos em defesa, oposição ou mesmo adesão a esta identidade política.

Todas as pesquisas consultadas apontaram experiências de discriminação das mulheres em relação à sua expressão artística do rap e às suas performances no palco do hip-hop. São vivências marcadas, muitas vezes, pela busca de impor limites às ações das jovens não apenas nos palcos, mas também relacionadas ao controle de seus corpos, desde a roupa que usam nas atividades do movimento, no seu comportamento sexual em relacionamentos dentro do grupo, além das próprias restrições vinculadas às oportunidades de trabalho no campo da música rap. (SILVA, 1995; MATSUNAGA, 2008; GOMES, 2008) Juntos, esses trabalhos contribuíram para demarcar a imagem das mulheres no Hip-hop, e, em especial, nas letras e performances do rap.

São compartilhadas pelas pesquisas conclusões acerca dos aspectos de manutenção de uma visão discriminatória em relação às mulheres diante da reprodução de uma hegemonia do modelo masculino como referência de "sujeito" legítimo àquele espaço, sob a afirmação da identidade negra e da periferia através da "cultura política” do Hip-hop. É o que mostra no Brasil o desenvolvimento de uma produção científica recente interessada na participação política das mulheres jovens.

Este "pensamento jovem feminista brasileiro" responde por um campo ainda em construção no país, portanto, uma categoria 
ainda não estabilizada, mas que se constitui pelos critérios de uma postura que se afirma feminista e jovem (sem exatamente uma faixa etária preestabelecida), estando preocupada em problematizar experiências de militância da juventude, em especial feminina, a partir de um novo olhar da teoria feminista sobre a pluralidade de expressões (diálogo entre categorias) do feminismo como movimento social.

No Brasil, pode-se citar o exemplo de uma publicação especial, uma coletânea que reúne em sua primeira versão trabalhos que se reconhecem jovens e feministas, intitulada por "Jovens feministas presentes” (2009). São trabalhos de jovens pesquisadoras preocupadas em ampliar o campo de atuação da teoria feminista, que trazem novas referências e experiências de atuação, organização e intervenção das mulheres jovens nos espaços de poder, tais como no movimento social, nos canais de participação e nas políticas públicas.

O artigo "Jovens no feminismo e no Hip Hop na busca por reconhecimento" busca analisar os desafios e alternativas encontradas pelas jovens mulheres inseridas no movimento Feminista e no movimento Hip-hop, dois espaços de militância bastante distintos. (ZANETTI; SOUZA, 2009) Julia Zanetti e Patrícia Souza expõem os conflitos geracionais e avanços conquistados no movimento Feminista em relação à juventude, além da contextualização do fenômeno Hip-hop no Brasil e no mundo, expondo a pouca participação das mulheres neste cenário.

Essas autoras concluem que, a partir dos anos 1990, com a atuação das mulheres do hip-hop e seu atrelamento com o campo do feminismo enquanto articulações e pautas, “o movimento feminista foi obrigado a reconhecer um novo grupo demandando espaço e visibilidade para sua própria forma de perceber e expressar suas questões”. (ZANETTI; SOUZA, 2009, p. 101) Da mesma forma, o hip-hop tem sido obrigado a reconhecer a participação do 
movimento de mulheres e feministas hip hoppers como parte dele. Esse é o primeiro trabalho que enfoca a relação direta do movimento de mulheres do hip-hop com o movimento Feminista, priorizando contextualizar seus conflitos e desafios. No entanto, elas não aprofundam questões em torno dos significados desse feminismo para o próprio movimento Hip-hop, que o produz de uma forma diferenciada em ação e pensamento de um feminismo apenas jovem, e, especialmente, em um movimento misto.

Já no artigo "Hip Hop Mulher: experiências de organização", Atiely Santos e Fernanda Sunega (2009) problematizam o conceito de participação política das mulheres hip hoppers para além do âmbito formal e partidário ao darem visibilidade às manifestações e intervenções nos espaços públicos das cidades ou centros urbanos. Além disso, a autonomia das organizações de mulheres é apresentada nas diversas articulações entre outras organizações, grupos, movimentos e instituições feministas.

As autoras destacam a relação desse movimento com o uso de novas tecnologias. Esse uso pode ser marcado em dois momentos. Num primeiro momento, já desde seu início nos anos 1970, nos Estados Unidos, e em seguida no decorrer de sua expansão pelo mundo nos anos posteriores, esse envolvimento esteve implícito com o uso e desenvolvimento dos toca-discos, microsystem, pick-ups, radiolas, fitas k-7, discos de vinil e outros. Alguns desses materiais ainda seguem os hip hoppers, em especial DJs em seu trabalho atual.

Num segundo momento, caracterizado por seu aspecto relativamente recente, há também a utilidade das ferramentas tecnológicas que são em primeiro plano, o acesso e aprendizagem para lidar com o computador e a internet, em segundo plano, pesquisas e produção de espaços virtuais, como sites e blogs, e participação em articulação em listas de discussão, $e$-mails, comunidades virtuais, dentre outros, no intuito de fortalecimento de contatos e 
divulgação de atividades das redes gerais e específicas, a exemplo de redes feministas virtuais do hip-hop. Tem se falado inclusive de militância virtual, muito utilizada por homens e mulheres hip hoppers para estabelecerem contatos e organizarem ações de pequeno, médio e grande porte pelo movimento.

Essa alternativa de participar, mesmo que virtualmente em muitos momentos, tem permitido e ampliado as possibilidades de trocas entre indivíduos e grupos de diferentes locais, como divulgação de atividades. A internet tem sido uma brecha para inserção do hip-hop, em especial para as mulheres jovens, muitas vezes sobrecarregadas por dupla e tripla jornada de trabalho ao cuidar de casa, crianças, estudo e trabalho que as ligam ao espaço doméstico,o que as diferencia em relação ao homem jovem, que não atende, em sua maioria, a essas funções vinculadas ao lar e à família, tendo, portanto, mais acesso ao espaço público.

No universo hip-hop brasileiro, o aspecto étnico-racial tem uma dimensão identitária relevante diante da maioria das jovens militantes do movimento Hip-hop que se autoidentificam como negras. Essa participação pode ser entendida como parte do rol da atuação das jovens feministas negras. Os desafios enfrentados pelas jovens negras para acessar espaços como os dos movimentos sociais se convertem em uma dupla barreira diante das discriminações raciais e de gênero (SILVA, 1995; CARVALHO; QUINTILIANO, 2009), além de fazerem referência aos contextos de classe e território nos quais a maior parte delas está inserida as periferias urbanas.

As experiências de mulheres em determinados grupos e segmentos do hip-hop soteropolitano servem de base para a criação de um movimento de mulheres interno ao Movimento. Questiona-se se essa organização de mulheres se constitui como parte do movimento Feminista, uma vez que compartilham algumas das suas lutas, tais como a autonomia feminina, a legalização do aborto, 
o empoderamento das mulheres, o combate à violência contra a mulher, dentre outros. Esses grupos e indivíduos teriam uma preocupação ou mesmo uma defesa de uma identidade politicamente feminista, basicamente feminina, ou nenhuma das duas posições? Também é importante observar que, dentre suas bandeiras, o movimento soteropolitano e de mulheres do Hip-hop também agrega as questões geracional e étnico-racial.

Tendo em vista tais questionamentos sobre as especificidades do movimento de mulheres do/no hip-hop, a fim de investigar as convenções de gênero e atitudes políticas engendradas nesse movimento soteropolitano, do ponto de vista das militantes, toma-se como hipótese de análise que esse movimento constitui-se a partir da combinação particular de três matrizes ou gramáticas políticas, a saber: movimento Feminista, movimento Negro e movimento de Juventude.

O movimento Feminista, muitas vezes, se apresenta como distinto do movimento de mulheres ou do movimento de mulheres negras, por se opor ao caráter classista e branco das primeiras gerações do feminismo. Esses movimentos têm bandeiras centradas no combate do sexismo e do racismo embasadas pelo combate à violência contra as mulheres. Outros aspectos importantes são as questões das mulheres negras discriminadas no mercado de trabalho, no que tange aos salários e postos de trabalho, muitas vezes negados a elas; há também a discussão e regularização de assuntos como trabalho doméstico, atendimentos nos serviços públicos de saúde, e outras questões.

Com relação ao movimento Negro, destacam-se a preocupação com formulações de leis e implementação de políticas de todos os setores, podendo citar em especial as de combate ao racismo, como leis de educação que interferem nos conteúdos de disciplinas do ensino fundamental e médio, na inclusão da história e cultura africana e afro-brasileira e nas políticas de ações afirmativas nas 
universidades públicas (estaduais e federais), a exemplo das políticas de cotas e programas de permanência estudantil. Dentre outros, há quatro temas vigentes nessa gramática política que devem ser mencionados aqui: a área de saúde da população negra, como o exemplo do caso da anemia falciforme; o direito à prática das religiões de matrizes africanas; o combate à intolerância religiosa; e a forma particular sobre como o racismo aflige as mulheres negras.

Já o movimento de Juventude é marcado pela luta por inclusão no mercado de trabalho sem os critérios de boa aparência mediante a apresentação de foto e, mais específico do Hip-hop, a profissionalização de seus elementos como trabalhos de arte-educação. O quesito violência se destaca contra homens e mulheres. Os homens jovens são vítimas da violência urbana devido ao extermínio da juventude negra, e as mulheres jovens vitimadas diante da prática do aborto inseguro. Ambos os temas relevantes elencados pelo Fórum Nacional de Juventude Negra no I Encontro Nacional de Juventude Negra (Enjune), realizado em junho de 2007, na cidade de Lauro de Freitas, Região Metropolitana de Salvador. (CARVALHO; QUINTILIANO, 2009)

Estas três gramáticas ou matrizes políticas compartilham o incentivo à afirmação de identidades e ao aprendizado para lidar com as diferenças. São três gramáticas que se mantêm em diálogo e constante interação na configuração desse cenário hip-hop soteropolitano.

Por conseguinte, a partir de inquietações acerca da atuação das jovens no movimento social Hip-hop, a investigação se dá em torno de como se configuram "as convenções de gênero e feminismos" no movimento Hip-hop em Salvador em relação à existência de um hip-hop feminista, jovem, negro, soteropolitano. Para tanto, como prioridade está a atenção à perspectiva das mulheres inseridas nesse movimento, sobretudo o interesse 
em compreender quais são suas concepções acerca do feminismo (ou o feminino), e investigar se há e quais são suas contribuições para as experiências destas mulheres diante de um contexto que dialoga com uma cultura política local vigente.

$\mathrm{Na}$ construção desta pesquisa, alguns questionamentos se desdobram a partir da questão central: existe um hip-hop jovem, feminista, soteropolitano? Se sim, como se constitui? Quais as suas concepções, referências e práticas em torno do modelo de feminilidade e de masculinidade que se expressam em suas convenções de gênero? Há feministas no hip-hop? O que elas entendem por feminismo? Há diferentes feminismos? Quais são suas distinções? Que tipo de feminismo estas constroem? Esses feminismos são capazes de apontar estratégias de superação das diferenças entre homens e mulheres e explicar as convenções de gênero acerca dos modelos de masculinidade e de feminilidade? Os homens podem ser feministas? Essas são algumas das questões que motivaram e orientaram esta pesquisa.

Ocorreu a adoção de algumas convenções na escrita deste livro de forma a identificar determinadas particularidades textuais. Para tanto, é utilizado itálico para identificar as falas das interlocutoras no corpo do texto e também para palavras estrangeiras. Utilizo letra tamanho dez para distinguir os fragmentos de notas do diário de campo, e aspas para destacar conceitos e expressões em uso. Vale destacar que, a fim de auxiliar a leitura, foi criado um glossário com o vocabulário do universo hip-hop.

No segundo capítulo, “O Hip-hop não para!”, são apresentados os aspectos teórico-metodológicos que orientaram a pesquisa, juntamente com as técnicas de investigação utilizadas para a sua realização.

O terceiro capítulo, "Hip-hop: coisa de menina? Convenções de gênero no movimento Hip-hop soteropolitano”, tem por objetivo identificar as convenções de gênero que embasam os modelos 
de feminilidade e de masculinidade, forjadas a partir de experiências vivenciadas no âmbito do movimento hip-hop soteropolitano, na perspectiva das mulheres militantes.

No quarto capítulo, "Hip-hop: espaço de contestação das convenções de gênero?”, são levantadas algumas interpretações sobre esse movimento como um espaço de contestação das convenções de gênero. As hip hoppers descobrem nesse movimento, mesmo que majoritariamente masculino, uma "brecha" para as mulheres e sua pauta política, interessadas em utilizar o aspecto de protesto do movimento como um instrumento capaz de contestar as convenções de gênero.

O quinto capítulo, "Agora os meninos precisam saber que coisa de menina também é coisa de menino! Hip-hop feminista?”, apresenta as considerações analíticas sobre as concepções de feminismos e discursos das hip hoppers em torno de um hip-hop feminista, enquanto apresento as conclusões da pesquisa. 


\section{O HIP-HOP NÃO PARA! ${ }^{14}$}

A partir da produção de uma ciência feminista ou de uma perspectiva feminista de ciência (SARDENBERG, 2002), configura-se o surgimento de uma teoria feminista que dialoga com as diversas experiências das mulheres e colabora com a análise das relações sociais de gênero nas quais elas estão envolvidas. Essa necessidade teórica de uma ciência feminista que considere os diferentes olhares sobre as mulheres, por sua vez, abrange algumas questões, como: o próprio questionamento acerca das manifestações do patriarcado e suas percepções; a quebra de um pensamento universal em termos das diversidades; e a ruptura com conceitos que hierarquizam as relações entre o masculino e o feminino.

Neste sentido, a construção de um pensamento feminista se constitui no diálogo da teoria com a prática cotidiana da vida das diversas mulheres em suas distintas configurações e relações. Para tanto, Maria Betânia Ávila (2000) define o feminismo pela composição entre prática política e pensamento crítico. Para autora,

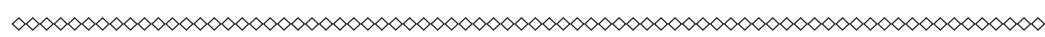

14 Este título pode ser considerado um dos lemas do hip-hop e traduz a resistência e persistência do movimento em sua luta, sentimento que compartilho na realização deste trabalho. 
Movimento Feminista é aquele que tem como perspectiva a transformação das relações de gênero, cujo foco de atuação é a luta por liberdade e igualdade para as mulheres, o que o torna um movimento contra a exploração e a dominação às quais estão sujeitas as mulheres. (ÁVILA, 2000, p. 6)

Pode-se compreender o feminismo como um projeto político que visa construir uma balança de equilíbrio de poder entre homens e mulheres, e, portanto, capaz de dar conta de reparar as desigualdades sociais referentes às relações de gênero. (COSTA; SADENBERG, 1994) Por gênero se compreende as relações sociais entre homens e mulheres, mulheres e mulheres, e homens e homens, em suas diversas possibilidades de interação, não podendo ser esse conceito usado como um sinônimo de mulheres.

Segundo Joan Scott (1992, p. 3), a compreensão da importância de gênero como categoria útil "exige a análise não só da relação entre experiências masculinas e femininas no passado, mas também a ligação entre a história do passado e as práticas históricas atuais". A partir do conceito trabalhado pela autora, dois pontos são relevantes para pensar gênero: 1) É o elemento fundamental das relações entre os diferentes sexos; e 2) Dá significado às relações de poder.

Isso pode ser explicado diante de alguns questionamentos fundamentais acerca dessas relações, que apenas podem ser respondidos através da análise da categoria gênero: como é que o gênero funciona nas relações sociais humanas? Como o gênero pode dar sentido à organização e à percepção do conhecimento histórico em diferentes épocas?

A partir dessa conceituação, as mulheres e os homens estariam inseridos em relações recíprocas e não mais de formas separadas ou naturalizadas. Essa separação entre homens e mulheres, ambos sujeitos políticos, é bem explicada por Maria Noemi Castilhos Brito (2001, p. 291): 
Historicamente, a construção das identidades de homens e mulheres se tem configurado a partir da dicotomia entre as esferas públicas e privadas, com atribuições de papéis, atitudes e valores previamente definidos segundo modelos naturais.

Portanto, essa identidade de gênero é construída social e culturalmente em cada sociedade em seu respectivo tempo e espaço.

É o que Maria Betânia Ávila (2000) explica quando defende o entendimento sobre a relação igualdade-diferença não como antagônica, mas como um dilema a ser enfrentado como parte do processo dialético da transformação social. Entretanto, chama atenção para a base de relações sociais desiguais na qual não se sustenta o ideal de igualdade, a exemplo de gênero. Ou seja, gênero atua em um campo em movimento, no qual estão reconhecidas as relações de poder em constante disputa, negociação e reconfigurações nos diversos âmbitos e espaços da sociedade. Dadas as dimensões, são as convenções sociais capazes de fornecer um "valor filosófico" a gênero.

Contudo, gênero abrange duas dimensões extremamente caras a esta análise. São as dimensões do simbólico (significados da cultura) e do político. De acordo com Alinne Bonetti (2003, p. 185):

A categoria analítica gênero articula concepção cultural e historicamente situadas, partindo, portanto, dos significantes disponíveis na cultura. Estes significantes são apropriados pelos sujeitos sociais, os quais lhes atribuem determinados sentidos.

Os significantes encontrados na cultura, que podem ser materiais e/ou imateriais e dão significado ao que é visto através do gênero, como se vestissem ou dessem significado a gênero. Assim, as relações sociais podem ser entendidas a partir das convenções de gênero. Em sua tese, a partir de uma perspectiva etnográfica feminista e que se desenvolve em um campo nordestino, "Não basta ser mulher, tem de ter coragem - Uma etnografia sobre 
gênero, poder, ativismo feminino popular e o campo político feminista de Recife - PE”, Alinne Bonetti (2007, p. 27) possibilita identificar as convenções de gênero particulares que

adotam de sentido as práticas políticas em embate, bem como os diferentes repertórios simbólicos que compõem o contexto politico em questão e nele se antagonizam. Possibilita o desvendamento de novas potencialidades para a compreensão das práticas políticas feministas.

Consequentemente, é a partir da cultura que se formam os valores, que, posteriormente, influenciam a construção dos sujeitos sociais. (BONETTI, 2003) Vale ressaltar que este processo de construção se dá diante de um contexto de desigualdades sociais.

De acordo com Donna Haraway (1995), há uma necessidade de compreensão de como significados e corpos são construídos. Para tanto, a autora defende o desenvolvimento de "saberes localizados”, não redutíveis, mas parciais diante de uma experiência corporificada. Para ela, estes "saberes localizados" significam uma objetividade feminista e corporificada que se inscreve como uma escrita feminista do corpo, portanto, limitada, parcial e situada. Essa ideia está atrelada ao fato de nos tornarmos responsáveis pelo que aprendemos a ver e pelo conhecimento que produzimos.

Já gênero, em sua dimensão do político, assume um caráter social, que denomina as relações de poder entre os sexos. Para tanto, gênero promove a distinção baseada no sexo, a fim de refutar o determinismo biológico implícito no uso de termos como "sexo" ou "diferença sexual". Além disso, essa categoria destaca o aspecto relacional das definições normativas da feminilidade e da masculinidade, que são construídos socialmente em distintos tempo e lugar.

Portanto, gênero utilizado sob uma perspectiva feminista permite a promoção de uma ruptura do binômio cultura-biologia, relacionado, respectivamente, a homem-mulher e público-privado. 
(ÁVILA, 2007) Ruptura essa importante por ampliar o entendimento sobre a definição do que é política a partir do diálogo entre as esferas pública e privada, anteriormente distintas e separadas.

O político se configurou em uma nova forma, de modo a ampliar a esfera pública capaz de abarcar a esfera privada. É o que aponta Maria Noemi Castilhos Brito (2001, p. 296) ao destacar as "novas dimensões para política e novas práticas significativas em outros níveis além do tradicional”, incorporadas a esse conceito, que não aceitam a representação do homem como sujeito universal atuante da esfera pública nem representante do político, além de reconhecer o político dentro da própria esfera privada e a interação entre ambas as esferas, pública e privada. O antigo binarismo público-privado não daria conta de explicar a realidade histórica vivenciada pelos sujeitos políticos e suas relações.

Para tanto, aprofundando a discussão sobre o campo do político como suporte para embasar este estudo, me apoio na compreensão de Sônia Alvarez (1998), a partir de seu artigo "Feminismos latinomericanos", estando em debate o campo político feminista a partir da experiência da América Latina. A autora propõe uma distinção entre o campo da "política" e o campo do "político".

Em sua definição, o campo da política é entendido como uma esfera da política mais clássica, tratada em seu sentido mais geral, enquanto a política pública trata de uma esfera mais específica. (ALVAREZ, 1998) Esse sentido mais clássico se circunscreve à instituições políticas, partidos políticos, cargos de representação política, espaços de atuação. (BONETTI, 2003) Como exemplo de alguns destes espaços ou canais de atuação estão os conselhos de direitos ou mesmo movimentos sociais e organizações não governamentais (ONGs).

Já o campo do político atual é "O sentido mais amplo de decidir sobre o cultural, o simbólico, e as relações de poder/gênero que 
ali são constituídos e continuamente reconfigurado". (ALVAREZ, 1998, p. 167 $)^{15}$ É nesse campo, interessado nos aspectos culturais e simbólicos, que se insere esta pesquisa, na interface entre "o gênero e o político" a partir da experiência das mulheres e seus "atributos de gênero" encontrados.

Segundo Alinne Bonetti (2003), o campo do político é eminentemente masculino; ao considerar seus valores e atributos de gênero, associam culturalmente o masculino ao modelo de sujeito dominante. Essa posição pode ser compreendida pela definição de Pierre Bourdieu (2007) para o campo político como um campo de forças, um campo de lutas em que relações e estruturas estão em disputa em um dado momento. Para o autor, é no campo político que são gerados produtos - entre eles, problemas, programas, análises, comentários, conceitos, acontecimentos - como "instrumentos de percepção e expressão do mundo social”, ou princípios de divisão, ou mesmo onde se dá a distribuição de opiniões (efeitos de censura entre o que é dizível ou não).

Portanto, é no campo do político em que se disputam as visões de mundo e se configuram gênero e suas convenções, havendo uma espécie de hegemonia (no sentido de direção) de um modelo de visão de mundo, no qual se definem comportamentos, valores, opções de consumo e etc. Essa visão de mundo que privilegia o masculino está em disputa dentro desse campo a partir da dinâmica de gênero vivida na sociedade, sob uma lógica de reciprocidade e troca social entre o feminino e o masculino.

É o que mostra a pesquisa de Alinne Bonetti (2004) ao investigar a atuação das Promotoras Legais Populares do Partenon (PLP), em bairro de Porto Alegre, em 1999. Segundo a autora,

Estudos sobre as concepções acerca do político entre grupos populares urbanos brasileiros revelam que a lógica

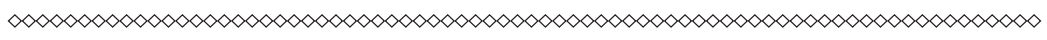
15 "En el sentido más amplio de incidir en lo cultural, lo simbólico, y en las relaciones de poder/ de género que alí se constituyen y se reconfiguran continuamente". 
de reciprocidade que informa as visões de mundo é estendida também ao mundo das relações políticas. A partir disso, salienta-se que o político adquire um significado particular dentro da lógica simbólica do grupo. (BONETTI, 2004, p. 136)

Contudo, o político do conceito de gênero é usado como ferramenta de análise de caráter interdisciplinar, em que "gênero" é assumido como uma categoria relacional para distinguir as configurações das relações de gênero vivenciadas na sociedade e/ou em um campo específico a ser analisado, estando inclusive aberto para considerações acerca da interação com outras categorias de análise a exemplo de raça/etnia, classe social, orientação sexual, sexualidade, idade/geração, dentre outras.

Para tanto, gênero apresenta-se como um conceito capaz de auxiliar estudos no campo da participação das mulheres e das convenções de gênero em experiências com o feminismo e o movimento social constituídos por segmentos de jovens.

Como exemplo do campo estudado, as hip hoppers (mulheres no hip-hop) revelam sua participação no movimento Hip-hop enquanto prática política a partir da exposição de demandas políticas das mulheres para o movimento e para a sociedade. (FREIRE, 2010) Em suas rimas, desenhos e iniciativas, expressam os desafios enfrentados pelas jovens que, no espaço público e privado, se deparam com formas de preconceito e discriminação por sua condição feminina. A partir de suas experiências, essas jovens reformulam os interesses do Hip-hop ao inseririrem pautas específicas na agenda política desse movimento. Para tanto, faz-se necessária a atenção a algumas categorias relevantes para se compreender esse fenômeno de forma mais completa.

Por isso, a necessidade de uma maior atenção para a categoria "geração" nos estudos de gênero e feministas é reconhecida e criticada pela socióloga Alda Britto da Motta (2004, p. 353), que afirma ser essa uma questão "quase invariavelmente omitida". 
Assim, é tratada a categoria "mulher adulta" como um sujeito universal nesse campo de estudo, configurando um "adultocentrismo", subalternizando outros segmentos atuantes no próprio movimento social de mulheres e/ou feministas.

Vale ressaltar que os primeiros estudos que referendaram especificamente a categoria juventude e visibilizaram essa participação tiveram início no contexto político dos anos de 1960 e 1970, influenciados pela experiência de participação dos movimentos sociais. (MOTTA, 2004) Esses movimentos foram representados em diversas ações em diferentes lugares do mundo, a exemplo do movimento Hippie, das mobilizações contra a Guerra do Vietnã, da "segunda onda" do feminismo, do movimento Estudantil e do movimento Negro. Essa geração até recentemente é reconhecida, e assim caracterizou a categoria juventude de sua época como constituída por uma série de elementos que a identificam como contestatória, revolucionária, interventora, entre outras.

Alda Britto da Motta (2004) ressalta a importância da percepção acerca das relações geracionais na dinâmica política e na reprodução social, e dos seus significados na contemporaneidade, como as interconexões com outras categorias como raça, gênero e classe social, e considera, ainda, a categoria geração um elemento fundamental para a construção de políticas públicas para todas as idades. Por geração, a autora entende que esse conceito "designa um coletivo ou grupo de indivíduos que vivem em uma determinada época ou tempo social, têm aproximadamente a mesma idade e compartilham de alguma forma uma experiência ou vivência” . (MOTTA, 2004, p. 350)

O campo pesquisado aponta para outro desafio teórico-analítico acerca da categoria geração. A definição do que seria uma geração jovem tem ultrapassado os limites de uma faixa etária em seu sentido cronológico de idade preestabelecido ou de um 
período determinado para viver um estilo ou modo de vida jovem. Para exemplificar essa questão, no hip-hop pode-se reconher alguns de seus representantes que ultrapassaram os 30 anos de idade, o que até então configuraria uma idade adulta, e não mais jovem, mas que representam a juventude hip-hop.

É o que mostra o estudo "Rap, juventude e identidade" realizado por Fernanda Martins (2004), que aponta para uma flexibilidade diante da concepção de idade, que tem se apresentado relativa diante da complexidade das práticas sociais do campo da cultura. É o que pode explicar a atuação dos rappers MV Bill (RJ) e Mano Brown, da banda Racionais Mc (SP), reconhecidos enquanto estilo jovem.

O entendimento acerca dessa participação, segundo Vera Cardoso (1994), está diretamente comprometido com o problema da cidadania, especialmente quando relacionado à atuação a partir do movimento social em sua vinculação com a história e com a luta por direitos coletivos de determinados segmentos sociais. A autora destaca a importância de ultrapassar a ideia de participação delimitada apenas à luta por justiça e conscientização, diante de uma ampliação da compreensão ligada à construção da cidadania, que por sua vez, abrange as relações entre Estado e sociedade civil, e entre esfera pública e esfera privada.

Portanto, a participação é a constante luta por garantia, manutenção e ampliação de direitos. Dentre as diversas definições de participação, aqui é entendida como a forma de intervir, como um sujeito político, nas decisões políticas e públicas da sociedade, bairro, comunidade ou grupo em que se vive e interage, sejam estas em diferentes dimensões, institucionais ou autônomas.

É o que explica Ana Alice Costa (1998), tomando a participação das mulheres, atreladas às suas demandas políticas e formas de participação, quando começam a se perceber e a serem percebidas como "sujeitos políticos” capazes de intervir na história e na 
política. É interessante notar que o percurso de participação das mulheres na luta por direitos específicos tem intervido na própria ideia de igualdade, e, sobretudo, tem implicado na criação de novas formas de fazer política e no reconhecimento de novos sujeitos políticos no cenário público. ${ }^{16}$

No tocante à juventude, de acordo com Celecina Sales (2001), a participação política formal em partidos políticos e canais de representação foi bastante influenciada pelo descrédito nesses espaços, diante do contexto da crise de representação política enfrentada por países latino-americanos nas últimas décadas. O cenário de corrupção, privilégios, nepotismo e, sobretudo, o descaso da justiça em apurar e punir esses políticos tem fortalecido - não apenas, mas especialmente - entre os jovens a ideia "não gosto de política". Embora tenha ocorrido certa mudança, é corrente ouvirmos falar que as pessoas não gostam e que não querem se envolver com a política.

Além disso, há que se considerar o contexto e conjuntura latino-americana pós-ditadura militar em que o Estado foi um inimigo extremamente repressor. Mesmo no início do processo de redemocratização, até recentemente, era comum o sentimento de participação antipartido, antiestado, antisistema político. (SALES, 2001; GOHN, 2003) Entretanto, houve a criação de alternativas de organização autônomas da juventude, inclusive alternativas distintas da representação partidária, responsáveis por uma mudança na forma de participar, que pode ser compreendida através dos movimentos sociais.

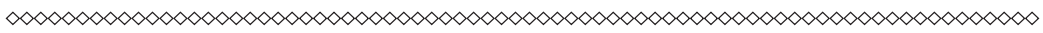

Essa afirmação pode ser brevemente contextualizada inclusive pela experiência dos movimentos feministas brasileiros e latino-americanos, que, no que seria considerada a segunda fase de alguns segmentos dos movimentos sociais, não tendo mais o Estado como inimigo, estão voltados para a relação com o Estado como aliado de suas demandas. Essa fase aponta para uma institucionalização da participação dos movimentos, garantindo uma nova forma de relacionamento entre movimento social e Estado, a exemplo do movimento de mulheres e feministas, das políticas públicas específicas para as mulheres. Entretanto, mesmo garantida no papel, há necessidade de constante luta pela sua implementação e aprimoramento, bem como pela própria efetivação e monitoramento destas. 
Há diversas interpretações para pensar a história e organização dos movimentos sociais em seus diferentes períodos, suas bandeiras e estratégias de luta. Por movimento social, Maria da Glória Gohn (2003) define um conjunto de ações sociais coletivas, de base sociopolítica e cultural, que tem por objetivo organizar de diversas formas a sociedade para reivindicar demandas e mudanças sociais. Essas ações sociais têm sido importantes na luta por cidadania, já tendo influenciado transformações políticas e sociais no decorrer da história da humanidade, a exemplo das manifestações e lutas populares.

No Brasil, a atuação dos movimentos sociais foi fundamental para a conquista de direitos registrados na Constituição de 1988 a partir dos movimentos sociais identitários, como o de mulheres, negros, homossexuais, jovens, idosos, indígenas e ecologistas. Maria Betânia Ávila (2000) contribui com esse debate ao reconhecer novos sujeitos e identidades, comprometidos pela luta por igualdade de direitos. Ela afirma que:

A pluralidade de sujeitos políticos, instituída pela ação dos movimentos sociais contemporâneos, revela que a construção da igualdade passa, justamente, pela desestruturação da ordem social, que hierarquiza as diferenças transformando-as em desigualdades. (ÁVILA, 2000, p. 6)

Essa ideia de novas identidades e estratégias de luta entre igualdade e diferença é o que justifica a posição compartilhada por Gohn e outros teóricos, que acreditam ser os anos de 1980 um período que permite embasar uma noção divisionista entre velhos e novos movimentos sociais.

Para Gonh, os que seriam chamados de velhos movimentos sociais têm uma motivação pelas lutas mais convencionais ligadas a necessidades materiais, como trabalho, moradia, alimentação. Esses eram os movimentos urbanos, camponeses, operários e de bairro e seriam identificados como movimentos reivindicatórios. 
Já os novos movimentos sociais utilizam a cultura como suporte para entender os processos de conflitos estruturantes das relações de poder na sociedade capitalista, que são compreendidos para além de termos econômicos e ideológicos. Conforme admite Maria da Glória Gohn, os novos movimentos sociais são entendidos a partir da criação de esquemas interpretativos voltados para "a cultura, a ideologia, as lutas sociais cotidianas, a solidariedade entre pessoas de um grupo ou movimento social e o processo de identidade criado”. (GOHN, 1997, p. 121) São diversos os motivos que incentivam suas mobilizações, estão entre eles: crises, desemprego, vulnerabilidade, lutas por moradia, por terra, por cultura e arte, contra a violência, entre outros. Estes eram os movimentos indígenas, étnicos, ecológicos, femininos, homossexuais e de direitos humanos. Estes seriam classificados como movimentos identitários.

A justificativa para essa divisão entre os tipos de movimentos tem base no uso das forças culturais, como se os tidos como velhos não as utilizassem e os novos as colocassem em uso em suas estratégias de luta. Entretanto, as autoras Sônia Alvarez, Evelina Dagnino e o autor Arturo Escobar (2000, p. 23) contestam essa ideia, afirmando que:

[...] os movimentos populares urbanos de favelados, de mulheres e outros, também põem em movimento forças culturais. Em suas lutas contínuas contra os projetos dominantes de construção da nação, desenvolvimento e repressão, os atores populares mobilizam-se coletivamente com base em conjuntos muito diferentes de significados e objetivos. Dessa forma, as identidades e estratégias coletivas de todos os movimentos sociais estão inevitavelmente vinculadas à cultura.

Portanto, a visão de separação dos movimentos sociais é contraposta pela explicação de Evelina Dagnino (1994), que defende que há uma luta por uma nova cidadania travada pelos movimentos sociais que se encontram sob o caráter de estratégia política. 
Entretanto, a demanda por uma nova cidadania está reservada para grupos que reivindicam o direito a ter direitos. Esses direitos estão vinculados em especial ao espaço urbano, constituindo uma demanda de direito à cidade por ambos os movimentos, sejam os movimentos urbanos e também identitários como os movimentos negros, de mulheres, LGBTT, e outros.

Objetivamente, esses grupos e movimentos pressionam uma transformação social pela construção de uma nova cultura democrática e, portanto, uma nova cultura de cidadania divergente da ordem hegemônica. Para tanto, a estratégia política utilizada por esses grupos e movimentos é contínua em sua construção, entendida como um processo embasado por lutas práticas e concretas, atualizadas diante da dinâmica dos conflitos sociais e ligadas ao seu momento histórico. (DAGNINO, 1994)

Apreende-se que a questão central deste debate sobre a existência ou não de uma divisão entre velhos e novos movimentos sociais não se sustenta. O que realmente está em jogo é o interesse acerca do que motiva a participação desses sujeitos. Concordando com a revisão sobre os movimentos sociais, Eder Sader (1988) acredita que o que mobiliza as pessoas são muitas questões definidas em volta da cultura como um aspecto fundamental. Essa ideia orientou sua pesquisa sobre as novas configurações sociais assumidas pelos trabalhadores da Grande São Paulo no curso da década de 1970, quando os movimentos sociais criaram novas formas e espaços políticos para tratar de questões em volta de releituras de temas presentes nas suas experiências cotidianas.

$\mathrm{O}$ autor aponta que as mudanças contestadas pelos movimentos podem ser resultado de um efeito retardado da repressão do regime ditatorial, que fez com que a sociedade civil surgisse expondo uma crise de representação e referenciais políticos, e reconhecesse o político para além do Estado e dos partidos. Ele justifica esse processo, “à medida que as modalidades da produção 
capitalística invadem todos os poros da sociedade, provocam também uma inédita politização no social e, com isso, um descentramento do político". (SADER, 1988, p. 54) É o “novo” no sentido de quebra com um modelo dominante que permite a criação de uma nova forma de fazer política que altera estratégias de ação e redefine valores. Nesse contexto, esses movimentos experimentavam uma nova socialização em que se desenvolviam relações de solidariedade entre os novos sujeitos políticos.

Outra colaboração relevante a esse debate vem de Ana Maria Doimo (1995), que aponta nova contribuição para as reflexões sobre a teoria dos novos movimentos sociais, especialmente em relação à abertura de um expressivo campo ético-político como reflexo do processo político brasileiro. Entretanto, diante de sua vasta experiência em contato com diversos movimentos sociais, e, em especial, o Movimento de Luta contra o Desemprego (MCD) (1982 a 1985), ela afirma que "tornava-se até constrangedor ter de dizer que ali, no MCD, não se encontrava um exemplo desses novos sujeitos políticos, destinados a tal ruptura, mesmo porque a realidade era cruel”. (DOIMO, 1995, p. 29) Esse contexto se colocava como desafiador aos movimentos diante da proposta de contraponto a uma cultura política dominante, sendo compartilhado por diferentes experiências de mobilizações, que lidam com questões em torno da ética na relação com Estado, institucionalidades, partidos políticos, lideranças e outros movimentos; e da própria ideia de luta imediata, fragmentação de grupos e bandeiras, e da possibilidade de um esgotamento da luta após a conquista de direitos.

Assim, a discussão em torno desta perspectiva sobre os movimentos sociais perdeu espaço para questões mais relevantes, como, por exemplo, as dimensões que compõem os movimentos e direcionam suas ações. Nesse sentido, Evelina Dagnino (1994) defende que todos os movimentos atuam sob estratégias democráticas 
direcionadas pelas dimensões da política e da cultura, estando localizados em seu específico tempo, espaço e contexto social.

Com isso, a dimensão cultural abarca os aspectos subjetivos em que atua o diálogo entre as múltiplas identidades constituintes dos novos sujeitos e suas necessidades de uma nova cidadania, que dê conta dessa diversidade. Contudo, essa demanda é um processo de aprendizado que interfere não apenas nas políticas e institucionalidades do Estado, mas tem seu foco nas relações sociais em todos os seus níveis. Especialmente no que tange à dinâmica social da sociedade civil para além do Estado e da política formalizada, em que a ordem defendida é o direito de participar e de exercer o direito de cidadã ou cidadão.

Nesse sentido, a atuação dos movimentos sociais inicialmente é caracterizada por uma prática de uma política criada pelos/para os grupos ou organizações autônomos, representantes da sociedade civil. Essa prática pode passar por um processo de institucionalização em relação a uma nova forma de se relacionar com o Estado - incidindo nas políticas públicas -, instituições, e outros grupos e movimentos, e também pode ser identificada como uma política cultural do movimento social que terá maior atenção em breve.

As autoras Sônia Alvarez, Evelina Dagnino e Arturo Escobar (2000, p. 21) concordam que "os movimentos sociais são uma arena crucial para a compreensão de como esse entrelaçamento, talvez precário, mais vital, do cultural e do político ocorre na prática". A referência da experiência dos movimentos sociais visibiliza o caráter ativo e relacional da cultura e da política que, reunidas em uma política cultural, atuam de forma a confrontar o que seria a cultura política hegemônica na sociedade.

Portanto, se os movimentos sociais pretendem modificar o poder social e se a cultura política abrange campos institucionalizados para a negociação do poder, então os movimentos sociais necessariamente enfrentam a questão da cultura política. 
Em muitos casos, os movimentos sociais não exigem inclusão ou mesmo a tomada de poder, mas antes buscam interferir e reconfigurar a cultura política dominante. Portanto, eles atuam de forma a modificar a cultura política vigente na sociedade.

Entretanto, a cultura política pauta a questão sobre o que conta como político, o que implica também em quem é ou quem são os sujeitos políticos. Para tanto, esse debate abrange diversas perspectivas. Assim, Norberto Bobbio (2000) compreende a cultura política como um conjunto de elementos que constituem determinada sociedade, no qual se incluem ideias e crenças, normas e tradições e instituições políticas. Segundo Maria da Glória Gohn (2005), há uma ligação entre os espaços do formal e do informal ao considerar a cultura política como o resultado do processo de educação vinculado à cultura, ao passado e ao cotidiano. Ambos os autores contribuem para a discussão, entretanto, não aprofundam a relação entre as práticas dos movimentos sociais e cultura política.

Já Evelina Dagnino, Sonia Alvarez e Antonio Escobar (2000) defendem que o conceito de cultura política entrelaça cultura e política, redefinindo os limites desta; torna capaz de reconhecer as relações de poder embutidas na cultura e que são responsáveis por dar significado às práticas sociais. Assim, essas autoras definem os conceitos de cultura e política de forma separada.

Para elas, cultura é

entendida como concepção do mundo, como conjunto de significados que integram práticas sociais, não pode ser entendida adequadamente sem a consideração das relações de poder embutidas nessas práticas. (DAGNINO; ALVAREZ; ESCOBAR, 2000, p. 17)

Política é algo mais que um conjunto de atividades específicas (votar, fazer campanha ou lobby), que ocorrem em espaços institucionais claramente delimitados, tais como parlamentos e 
partidos, ela deve ser vista como abrangendo também lutas de poder realizadas em uma ampla gama de espaços culturalmente definidos como privados, sociais, econômicos, culturais e assim por diante. (DAGNINO, ALVAREZ; ESCOBAR, 2000, p. 29)

Enfim, esse laço constitutivo também significa as relações de poder, que não podem ser entendidas sem o reconhecimento do caráter "cultural ativo" para a compreensão de suas expressões e significados. Portanto, a cultura e a política estão intrinsecamente associadas e mutuamente se influenciam e se constituem. Assim explicam Dagnino, Alvarez e Escobar (2000, p. 24-25):

A cultura é política porque os significados são constitutivos dos processos que, implícita ou explicitamente, buscam redefinir o poder social. Isto é, quando apresentam concepções alternativas de mulher, natureza, raça, economia, democracia ou cidadania, que desestabilizam os significados culturais dominantes, os movimentos põem em ação uma política cultural.

Assim, a prática dos movimentos sociais pode ser compreendida por política cultural, que se supõe resultado de concepções e visões de mundo de grupos minoritários que se relacionam com uma determinada ordem cultural dominante. Em diálogo com o campo interdisciplinar estão alguns estudiosos que se dedicaram a pensar sobre esse assunto; estão presentes cientistas políticas(os) e antropólogas(os) em especial, interessadas em entender o que seriam realmente as novas práticas políticas e as propostas de "novas culturas políticas", mais especificamente construídas a partir das experiências dos movimentos sociais.

Vale ressaltar que essas práticas dos movimentos são expressas de várias formas, a exemplo dos debates políticos que criam ou dão novos significados às interpretações culturais dominantes da política e que desafiam sujeitos e práticas políticas estabelecidas como hegemônicas. Para tanto, Dagnino, Alvarez e Escobar (2000, p. 24) defendem 
as contestações culturais não como meros 'subprodutos' da luta política, mas ao contrário, são constitutivas dos esforços dos movimentos sociais para redefinir o sentido e os limites do próprio sistema político.

A importância está em participar e contribuir com o debate e decisões públicas que interferem na vida da população e das diferentes gerações. Essa forma de participar é nova, pois está aberta para inovações e reconfigurações, com novos espaços, sujeitos, meios e instrumentos. É o que explica Sader (1988, p. 32-33):

Pequenos atos, que até então seriam considerados insignificantes ou reiteração de uma impotência, começam a receber novas conotações. Manifestações incapazes de incidir eficazmente sobre a institucionalidade estatal - antes interpretadas como sinal de imaturidade política - começam a ser valorizadas como expressão de resistência, de autonomia e criatividade.

Adentrando no campo desta pesquisa, o "novo" espaço criado pelo hip-hop enquanto expressão artística e cultural entrou na cena dos movimentos políticos. O Hip-hop foi considerado um dos fenômenos mais importantes no mundo atual, e chegou até a ser classificado por Maria da Glória Gohn (2004), em sua interpretação teórica, como inserido no rol dos novos movimentos sociais, justificado por este integrar três perspectivas: 1) Possibilita a inclusão de novos atores e atrizes no contexto de luta política, implicando na construção de identidade; 2) Utiliza a cultura como ferramenta política na luta por direitos e cidadania; e 3) Está vinculado ao campo internacional e à esfera tecnológica em sua história.

Para a estudiosa Priscila Matsunaga (2006. p. 12), o Hip-hop é "o novo dos novos movimentos sociais" porque

[...] promove a construção de atores/sujeitos que reivindicam, num primeiro momento, um reconhecimento de sua existência; 
reivindicam direitos e garantias sociais e se constituem como um grupo que atua politicamente utilizando a arte.

À ideia de novo está vinculada a contextualização histórica do hip-hop, em seu percurso de formação e expansão pelo mundo, bem como através das experiências de suas diferentes gerações e espacialidades que o configuram como movimento social.

Por hip-hop entende-se a composição de manifestações que se expressam através das artes de matrizes culturais africanas, caribenhas e americanas, atreladas a aspectos modernos - entre eles, a própria união de diversas matrizes culturais, a reconstrução de identidades na diáspora - e tecnológicos. Sua origem remonta aos anos 1970, quando jovens afroestadunidenses e imigrantes caribenhos e latinos residentes do Bronx, bairro periférico de Nova Iorque (EUA), deram forma ao Hip-hop e aos seus elementos básicos: break, rap, grafite e DJ (SANTOS; SUNEGA, 2009), como já referido anteriormente.

Todas essas artes expressas pelo hip-hop e que configuram os elementos com linguagem desta cultura juvenil não se restringem apenas ao âmbito estético e musical, também produzem discursos para a luta política, tendo em sua essência a educação - informal, produzida na rua em diversos espaços urbanos e situações do cotidiano - estimulada e embasada na atuação da juventude. Essa característica pode ser compreendida a partir do conhecimento da constituição do hip-hop e seus elementos, o qual acontece nos Estados Unidos inserido num cenário político pós-movimento por direitos civis, ocorrido durante os anos de 1930 e 1950.

A luta pelos direitos civis influencia e fornece a primeira geração hip-hop nos Estados Unidos, que, posteriormente, será também referida às próximas gerações em outros países, em distintos 
aspectos. Em relação às lideranças, ${ }^{17}$ destacam-se personalidades, a exemplo de Rose Parks, ${ }^{18}$ Martin Luther King, ${ }^{19}$ Malcolm $\mathrm{X}^{20}$ e Angela Davis ${ }^{21}$ e as formas de organização de grupos políticos como os Panteras negras. Também são importantes as diversas estratégias de participação política como boicotes de ônibus, passeatas, produção de jornais e outros.

O surgimento do Hip-hop foi marcado pela reunião de seus elementos que já existiam em separado, como o break e o grafite, conhecidos como os velhos elementos (the old elements). Inicialmente, esses elementos foram utilizados como uma alternativa de lazer para a juventude negra e latina dos bairros da periferia, que viviam sob uma realidade de violência entre gangues, as quais disputavam espaços, ideologias e tinham um intenso envolvimento com o tráfico de drogas. É neste contexto de embate social que o hip-hop se transforma em uma alternativa política.

A juventude hip-hop - conhecida nos Estados Unidos como hip-hop generation ${ }^{22}$ e/ou post-soul - reconhece questões em

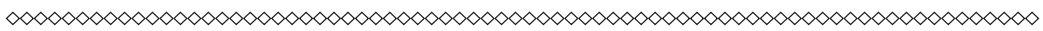

17 Personalidades atuantes durante o movimento por direitos civis nos Estados Unidos que se destacaram como lideranças e representantes da população negra, que lutavam por direitos iguais e combate ao racismo, e tornaram-se referencias dessa luta por todo o mundo e, sobretudo, para as gerações seguintes.

18 Rose Parks foi presa e multada por ter se recusado a ceder seu lugar no ônibus a um branco, contrariando o que estava previsto na lei de segregação racial em seu país. Seu ato deu início ao que foi chamado de "Boicote de ônibus de Montgomery" (Alabama). (ALVES, 2011)

19 Martin Luther King Jr., pastor da igreja batista na Geórgia, tinha sua militância inspirado no líder indiano Mahatma Gandhi, e conhecido especialmente por seu discurso na Marcha de Washingthon, em 1963, intitulado I have a dream, um sonho de que o respeito às diferenças fosse alcançado em seu país e no mundo. Luther King liderou, juntamente com outras pessoas, os boicotes aos ônibus e às leis de segregação racial, que duraram 381 dias, tendo como resultado, entre outros, a quebra de inúmeras empresas de transporte. (ALVES, 2011)

20 Malcolm X, como era chamado Al HajjMalik Al-Habazz, importante referência da luta pelos direitos da população negra nos Estados Unidos.

21 Angela Davis, professora e escritora, importante militante do movimento Black Power, candidata em duas eleições presidenciais pelo Partido nos Estados Unidos durante os anos 1980.

22 Termo dado para identificar o segmento da juventude negra estadunidense nascida entre os anos de 1960 e 1980, que compartilhava um sistema de valores herdado pela geração anterior, cunhado nos anos de 1990, por Bakari Litwana, editor da The Source: Magazine of Hip Hop, Music Culture and Politics. Posteriormente, essa juventude foi chamada por Mark Anthony Neal de post-soul, pois descrevia as experiências culturais, sociais e políticas da população negra estadunidense desde o final dos movimentos por direitos civis e Black Power. (COLLINS, 2006) 
comum entre pessoas e bairros negros e latinos a partir da cultura hip-hop como parte de um fenômeno global. Segundo Collins (2006), essa juventude afro-estadunidense alcançou visibilidade da mídia para aprofundar os debates em torno das questões de gênero, raça, nacionalidade, idade e sexualidade, refletindo as contradições do novo racismo, vivenciando o contexto de explícitas leis de segregação racial e o ideal de oportunidades da "América" livre.

Essa juventude negra e latina estadunidense passou a se organizar e promover ações de socialização de grupos pela não violência de gangues, iniciando batalhas artísticas de dança e de rimas improvisadas. É nesse contexto político que surge a Zulu Nation, a primeira organização do movimento, responsável por promover o hip-hop e seus elementos em âmbito internacional, tendo como lema a conscientização da juventude através da educação (informal e do cotidiano urbano-artístico). Essa organização pode ser encontrada em praticamente todos os continentes, e foi responsável por politizar a cultura hip-hop e tratá-la como um instrumento de luta política. Dessa forma, ela é reconhecida pelos segmentos do movimento social hip-hop baiano, tendo representantes em Salvador.

O Hip-hop é identificado por Stuart Hall (2003) e Paul Gilroy (2001) - embasados pelos estudos descoloniais ${ }^{23}$ - como uma das expressões culturais da diáspora africana. Com o conceito de diáspora, os autores pretendem abarcar um novo momento de sociabilidade de uma população ou de um grupo étnico marcado por processos de deslocamento, fuga, exílio, migração forçada na reconstituição da identidade, acreditando que esse conceito pode ser usado na substituição do termo "raça". Ele permite também explicar a conexão entre hip-hop, juventude negra e vivência em

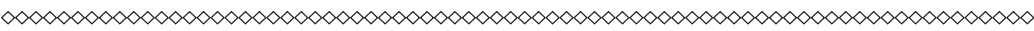

23 Por estudos descoloniais entendo os estudos embasados na desconstrução de um modelo hierarquizado e subalterno de produção de conhecimento, tratando de temas atuais como identidades, migrações, território, diáspora e outros. 
bairros periféricos caracterizados pelas desigualdades sociais e identificados pelas categorias de raça, de classe, de geração e de espaço (no caso, urbano e periférico).

O termo diáspora auxilia na compreensão do contexto social no qual o Hip-hop surgiu e se desenvolveu nas décadas seguintes nos Estados Unidos e também no Brasil, como em outros países americanos, caribenhos, europeus e até africanos em diferentes configurações. O surgimento do Hip-hop nos Estados Unidos e no Brasil compartilha condição de uma alternativa de lazer, divertimento e mecanismos de contenção e substituição da violência física das brigas de gangues pelas "batalhas" artísticas em seu primeiro momento. Posteriormente, ele tornou-se movimento político munido das expressões artísticas de seus elementos, como apresentado anteriormente.

No decorrer da primeira geração do movimento baiano, foi extremamente rica a mudança de participação e organização social da juventude negra baiana do movimento Hip-hop, voltada inicialmente para preocupações com sua comunidade e o entendimento sobre questões de sua identidade e história, e, posteriormente, para a ampliação de seu campo de ação na cidade e o envolvimento com a discussão acerca das políticas públicas comprometidas com o desenvolvimento da comunidade negra.

Como exemplo dos temas envolvendo essas políticas estão: a Lei $n^{\circ}$ 10.639/ 03 de inclusão da história e cultura da África e afro-brasileiras nos currículos escolares; atenção à saúde da população negra e, em especial, à anemia falciforme; ações afirmativas e cotas no ensino superior; regulamentação do trabalho doméstico, combate à violência contra a mulher, dentre outras. Ações que se desenvolvem de forma articulada com outros segmentos, que atuam a partir do diálogo "com o poder público local, promovendo interação entre as demais cidades brasileiras, e realizando 
encontros nordestinos e de gênero, com um grau de organização muito próprio". (OLIVEIRA, 2007, p. 66)

As artes do hip-hop tornam-se um instrumento que expõe a condição dos/das jovens e da sua reivindicação de direitos junto ao poder público. (MATSUNAGA, 2008) A juventude hip-hop baiana realiza, através dos elementos artísticos do movimento, denúncias das desigualdades sociais vivenciadas pela população negra, jovem e pobre das periferias soteropolitanas. São exemplos as intervenções públicas na campanha "Hip-hop pelas cotas", feitas na reitoria da Universidade Federal da Bahia (UFBA), com a apresentação de break, de bandas de rap, de performances de uma djeia ${ }^{24}$ - praticamente a única djeia do estilo hip-hop - ${ }^{25}$ e de DJs e exposições de grafites, além da promoção das mesas de debates com integrantes do movimento e convidados representantes de outros segmentos do movimento negro. Esse evento está registrado no documentário produzido pela TVUFBA, além da própria universidade ter produzido um single com a música "Quadro negro” da banda Simples Rap'ortagem. (OLIVEIRA, 2007)

Na Bahia, o surgimento do Hip-hop na década de 1990 se deu num período em que a participação das mulheres no movimento ganhou visibilidade no cenário brasileiro através de intervenções de algumas hip hoppers icônicas, que ajudaram a constituir grupos e ações do Hip-hop no país. Essa década teve um importante significado em relação à participação e identidade das mulheres negras, segundo Maria Aparecida da Silva (1995, p. 516), pois “[...] o surgimento da organização do movimento de mulheres negras no Brasil é concomitante ao surgimento das primeiras rappers”.

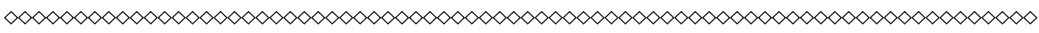

24 Djeia é um termo do campo, utilizado pelas mulheres do próprio movimento para nomear aquelas que atuam com o elemento musical DJ.

25 Sendo mais frequente encontrarmos Djeias de estilos de músicas eletrônicas, a exemplo do estilo techno.
} 
É nesse contexto que as jovens baianas se inserem nos espaços do movimento Hip-hop em Salvador, sob a compreensão de que esse movimento se constitui num dos segmentos do movimento negro baiano em sua primeira geração. Afinal, o que impulsiona as jovens negras do hip-hop a se mobilizarem?

Essa resposta tem lugar nas discussões sobre os temas pautados por integrantes do Hip-hop e surgem a partir das experiências do próprio cotidiano dessas jovens, interferindo nas pautas do movimento. Sobre a diferença entre as experiências de homens e de mulheres, a rapper baiana Mara Asantewaa pontua:

Não porque exista um papel para um ou para outro, mas é porque a realidade de uma mulher é diferente da realidade de um homem, principalmente quando é o movimento social, inclusive quando é o hip-hop. (SOUZA; SANTOS, [2009])

A fala da rapper aponta um caminho a ser perseguido para a compreensão dos modelos de feminilidade e de masculinidade e suas convenções de gênero no movimento e na sociedade, foco desta investigação.

\section{Questões metodológicas}

Esta pesquisa qualitativa contou com o trabalho de campo dividido em dois momentos. O primeiro momento ocorreu durante a primeira fase da pesquisa, em 2008, em vias ao trabalho monográfico do bacharelado em Ciência Política, com a realização de entrevistas e observação participante. Esse material serviu de base para este livro, já que no trabalho anterior não me foi possível explorar todo o material coletado.

No segundo momento, ocorreu o retorno ao campo de março a agosto de 2010, ao revisitá-lo com um olhar sob uma forma interdisciplinar e interessada na etnografia do cenário pesquisado. 
Assim como Angela Maria de Souza (2009), que desenvolveu seu trabalho sobre o movimento Hip-hop em Florianópolis em dois momentos distintos, também tive a oportunidade de revisitar o campo em Freire (2010).

Durante o intervalo entre os períodos dos trabalhos de campo, mantive contato com as interlocutoras e informantes, além de eventuais encontros em atividades outras pela cidade. Nessas oportunidades, trocamos informações, tiramos dúvidas sobre determinadas questões e eu as atualizava do andamento do trabalho e/ou escrita do "nosso livro", como algumas delas se referiam. ${ }^{26}$

Em se tratando de uma pesquisa de caráter feminista e interdisciplinar, faz-se relevante refletir sobre as questões metodológicas que orientaram essa investigação. Primeiro, com respeito à mudança de orientação metodológica em meio ao processo de escrita, entre a ciência política e a antropologia. Assim, a análise que se apresentará tem esse duplo pertencimento.

Outro aspecto que importa destacar está direcionado à perspectiva feminista que embasa esta pesquisa. Essa perspectiva se traduz ao analisar as relações de gênero, entendo-as como relações de poder, que são vivenciadas entre homens e mulheres na sociedade, a qual, segundo Betânia Ávila (2007), é capaz de perceber a mulher como "sujeito político" do processo de transformação social, interferindo nos processos sociais. Essa concepção permite a possibilidade do rompimento com a perspectiva naturalista de vitimização e fragilização das mulheres.

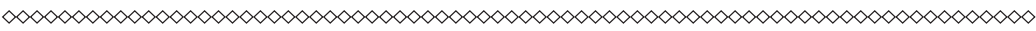

26 Após finalizar meu trabalho de campo, durante os meses de outubro e novembro de 2010, em meio à experiência do intercâmbio na Universidade Federal de Santa Catarina (UFSC), em Florianópolis, ocorreu a oportunidade de conhecer o campo de trabalho estudado por Angela Souza (2009) na cidade - já que a pesquisadora também investigou o hip-hop em Lisboa. Nessa experiência, tive contato com um segmento do movimento Hip-hop: o hip-hop gospel. Além de conhecer expressões de seus trabalhos quando visitei uma igreja evangélica, assisti a uma apresentação de uma banda de rap e à exibição de um dos seus videoclipes. A igreja referida garantia equipamentos e material de qualidade para as produções. Segundo Angela, os hip hoppers gospéis colocavam que adentravam hoje em lugares que nem polícia nem pastores entravam. Também nessa oportunidade marcamos com uma rapper que não pertencia a esse segmento gospel do Hip-hop, mas infelizmente ela não compareceu ao encontro marcado. 
Outra premissa estabelecida pela perspectiva feminista sobre a qual se apoia este estudo é embasada pela experiência de buscar novos referenciais teóricos para analisar o comportamento feminino. (BRITO, 2001) Além disso, a direção foi a um relativamente novo contato com o campo da antropologia e da etnografia feminista. (HARAWAY, 1995; SARDENBERG, 1998; BONETTI, 2007)

A escolha em ressaltar a produção de um conhecimento situado (HARAWAY, 1995) está embasada pela pesquisa que se aproxima da etnografia, sem que haja a pretensão ao olhar exatamente de uma antropóloga, inclusive reconhecendo a base da ciência política, mas disposta a refletir acerca das ubiquidades (BARROS, 2007) na aproximação da relação e da identidade com interlocutoras de sua pesquisa. Por isso, esta pesquisa pretende passear pelo campo da antropologia e de uma produção de cunho etnográfico.

Ao pensar os desafios do campo, já nos primeiros contatos com o movimento Hip-hop, foi percebido que havia algumas questões que, de certa forma, fechavam ou limitavam o contato das pessoas e grupos com pesquisadoras. Havia um receio por parte do movimento social em disponibilizar informações ou mesmo abrir seu espaço para pessoas de fora. Para compreender esse campo, primordialmente, fazia-se necessário "olhar o mundo do ponto de vista dos nativos" (GEERTZ, 1997), embora não estivesse estabelecida a pretensão de realizar uma etnografia, mas de utilizar estratégias etnográficas para compreender aquele cenário, e das suas principais questões e constrangimentos. Postura defendida por Clifford Geertz (1997) - em seu estudo sobre os javaneses, balineses e marroquinos - para que o olhar da pesquisadora não sobressaia em relação ao grupo pesquisado, ou vice-versa, para que não haja uma hierarquia entre eles, e se possa apreender os sentidos e símbolos do cenário que os rodeiam, em que se inserem sentimentos, expectativas e ponto de vista. Uma lição para nos abrimos para a compreensão do campo em questão. 
Nesse sentido, essas "restrições" em torno das pesquisas que continuavam acontecendo - seriam uma espécie de defesa do Movimento ao uso da sua imagem e ao acesso das suas informações por parte de pesquisadores. Essa ideia de preservação do próprio movimento é compartilhada por muitos dos que podemos chamar de movimentos sociais, grupos culturais e religiosos, bastante procurados para fins de pesquisa por estudiosos locais e internacionais, justificados muitas vezes devido à falta de retorno desses trabalhos de pesquisa para seus pesquisados. Para tanto, o movimento Hip-hop cria alternativas possíveis para, como é chamado por eles mesmos, uma relação de feedback - relações de trocas e parcerias entre o movimento e pesquisadoras(es) do tema. Essa oportunidade cria vínculos entre a pesquisa, a pesquisadora e as(os) pesquisadas(os).

No que seria o primeiro momento desta pesquisa, durante a graduação, desenvolveu-se ações importantes, tendo a relevância da experiência do curso de inglês "I have a Dream: English for Black Empowerment" ${ }^{27}$ para o movimento Hip-hop e outros movimentos sociais, no ano de 2007, no Centro de Estudos AfroOrientais (CEAO)/28 UFBA. (FREIRE, 2010) Essa experiência foi extremamente rica em vários sentidos: ampliação do contato com integrantes do movimento; afirmação da posição como pesquisadora do tema, e a criação de uma oportunidade de troca com o movimento a partir de suas demandas principais: educação e ampliação de estratégias de oportunidade de trabalho para a

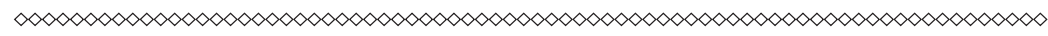

270 curso consistiu numa parceria do Núcleo de Mulheres da Rede Aiyê Hip-Hop, um dos segmentos do movimento Hip-hop em Salvador, reunindo diversas posses, e o grupo We are problematic! English for Black Empowerment - formado pelo grupo de estudantes de Ciências Sociais/ UFBA, integrantes do programa de intercâmbio "Raça, Desigualdades e Desenvolvimento: uma comparação Brasil e Estados Unidos" (UFBA e Vanderbilt University), autoras do material didático e responsáveis por ministrarem as aulas. Participei desse grupo e do projeto como propositora.

28 Centro de Estudos Afro-Orientais (CEAO) é um órgão suplementar vinculado à Faculdade de Filosofia e Ciências Humanas (FFCH) da Universidade Federal da Bahia (UFBA). Esse centro abriga projetos de pesquisa e atividades abertas à comunidade envolvendo temas da história e cultura afro-brasileiras. Disponível em: <http://www.ceao.ufba.br/2007/apresentacao.php>. 
juventude negra e da periferia - no caso, aprender inglês, seja para os vestibulares ou para o mercado de trabalho. A iniciativa reuniu diferentes grupos de jovens, sendo bem-vista pelo movimento e organizações. O curso não teve continuação por falta de recursos para sua gerência.

Refletindo sobre situações da pesquisa durante uma conversa com a rapper Mara Assantawaa, esta colocou que durante certo tempo decidiu "não mais conversar com pesquisadores" diante de complicações entre a relação pesquisador-pesquisados. Um dos casos relatados se refere ao conhecimento, durante o trabalho de campo, na descoberta de fotos dos grupos de hip-hop baianos em publicações como revistas e pesquisas europeias e estadunidenses, sem que esses grupos sequer tenham ciência de quem os registrou, sem autorização prévia ou sem retorno para o grupo.

Devido a uma aproximação e participação ${ }^{29} \mathrm{em}$ atividades do Movimento, havia um receio de dois lados - por parte do movimento e por parte da academia - acerca de uma possível confusão em relação ao meu pertencimento àquele movimento e ao distanciamento necessário para a realização da pesquisa, justificado pela relação de parceria com os grupos pesquisados. Essa era uma preocupação pessoal, e sempre que era oportuno situava o lugar e o objetivo da presença nesses espaços como pesquisadora. ${ }^{30}$

29 Em outras oportunidades, participei como palestrante, apoio administrativo, fotógrafa e filmaker em eventos e ações do movimento.

Duas oportunidades que reconheceram minha posição com relação a este trabalho foram dois importantes convites para apresentação da pesquisa. 0 primeiro foi para participar de uma mesa de debate no Seminário Coisa de Menina (2010), pelo movimento de mulheres do hip-hop, referente ao trabalho da graduação, e o segundo foi o convite para participar da abertura da calourada do curso de graduação em Gênero e Diversidade (2011), FFCH/UFBA, pelas professoras universitárias. Nessa segunda experiência, fui convidada pelas professoras do curso, vinculadas ao Núcleo de Estudos Interdisciplinares sobre a Mulher (NEIM), o qual é responsável pelo curso de graduação em Gênero e diversidade (bacharelado), e pelo Programa de Pós-graduação em Estudos Interdisciplinares sobre Gênero, Mulheres e Feminismo (PPGNEIM), ao qual está ligada esta pesquisa. 0 objetivo da apresentação, a partir da realização desta pesquisa, foi de ligaçãa entre a graduação e a pós-graduação, e tive a oportunidade de convidar duas rappers - Mara Assantawaa e Jamile Santana - para apresentarem seus respectivos trabalhos sobre o tema das mulheres. As atividades foram planejadas juntamente com as professoras do colegiado do NEIM, 
Esse foi um desafio que esteve presente, em especial, no primeiro momento da pesquisa (graduação), e que foi amadurecido na pós-graduação.

O contato com as jovens foi extremamente importante para garantir a compreensão acerca do universo hip-hop, de suas linguagens e dos símbolos utilizados por suas/seus integrantes, especialmente em torno das gírias, roupas, penteados e outros, de forma a identificar o conhecimento situado nesse universo. Durante o decorrer da pesquisa, foi mantido o contato com as mulheres do hip-hop em diferentes oportunidades, como reuniões dos grupos (quando possível), atividades públicas e interações com outros movimentos e de pautas gerais em que o movimento Hip-hop estivesse presente, no intuito de perceber o modo de atuação e como se dão as relações sociais internas e externas.

Assumindo o método qualitativo de pesquisa, sob o olhar da epistemologia feminista, trabalho com entrevista em profundidade do tipo semiestruturada com um único correspondente. (GASKELL, 2002) Para tanto, as técnicas de investigação utilizadas foram: a realização de entrevistas com roteiro semiestruturado junto às hip hoppers, e observação participante oriunda da convivência junto ao grupo estudado, com o suporte da confecção de diário de campo, que permitiu a construção de um cunho etnográfico para este trabalho, além da coleta de material audiovisual e impresso sobre os grupos e atividades, CDs, DVDs, materiais de jornais e revistas, fanzines, material fotográfico e outros.

A observação participante desenvolveu-se no processo de convivência junto às hip hoppers dentro de uma intensa agenda de mobilizações, sendo importante para perceber como ocorrem as relações entre as pessoas do grupo pesquisado e o próprio ambiente em que atuam. Vale destacar que inúmeras vezes foi

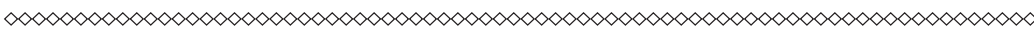
em especial, Professora Sílvia Aquino, a partir da construção de acordos e trocas entre o Núcleo e as hip hoppers. 
explicado o motivo que justificava esta presença em campo. Inicialmente, explicava de forma mais detalhada e descrevia a proposta do projeto. Depois, apenas dava informação sobre a realização de uma pesquisa sobre um suposto "Hip- hop feminista", o que já prendia a atenção e curiosidade das e dos hip hoppers, os quais explicavam uns aos outros o meu trabalho de escrita do livro sobre as mulheres do Movimento. Durante a inserção em campo, a postura assumida como pesquisadora era de estar aberta para perguntas dos indivíduos e dos grupos sobre esse trabalho, especialmente às lideranças do movimento, bem como em pedir seu o apoio e colaboração, como parceiras interlocutoras/es, para a realização desta pesquisa.

Foi fundamental o contato direto com indivíduos-chave do grupo estudado para garantir a transparência do trabalho e o trânsito no ambiente em questão, especialmente para as pessoas que lideravam ou estavam à frente das articulações, pois estas poderiam repassar meu objetivo ali, por outras vias, e internamente. Além disso, em diversos momentos ocorreu o contato com diferentes informantes-chave e colaboradoras para a pesquisa, com diálogo aberto e muito valioso sobre questões delicadas do trabalho de campo.

Diante de tantas articulações provocadas pelas perguntas à pesquisa, foi apreendido as observações compartilhadas por Willian Whyte em sua pesquisa com os Norton, em Corneville, em 1937. Ele relata que na observação pôde ter, "sentado e ouvindo, as respostas às perguntas que nem mesmo teria tido a ideia de fazer se colhesse minhas informações apenas por entrevistas” (2005, p. 304). Imersa no ambiente de estudo, o esforço em observar as hip hoppers, que mesmo diante do compartilhamento de interesses e inquietações, embora de perspectivas distintas, lembravam-me frequentemente sobre nossas distinções de lugar de fala. Observações essas que produziram a confecção do diário de campo como técnica para registro 
sobre o que se encontrou no campo estudado - a cidade de Salvador -, em seus percursos, lugares, encontros, shows, personalidades, seminários ou/e questões que envolviam o hip-hop. Além disso, nas notas sobre o campo também constam observações das entrevistas realizadas de conversas informais no debate e elucidação de dúvidas com as informantes.

As entrevistas realizadas junto às hip hoppers foram auxiliadas pelo roteiro semiestruturado, sendo que algumas delas foram reconectatadas (algumas vezes) para elucidar dúvidas sobre tópicos do roteiro. A seleção da amostra de entrevistadas ocorreu sob os seguintes critérios de escolha: 1) Ser militante do movimento hip-hop; 2) Ter participação (anterior ou atual) em coletivo de mulheres ou em grupos mistos; 3) Ser independente ou mesmo parceira do movimento; e 4) Ter envolvimento com os elementos do hip-hop desenvolvendo técnicas para fomentá-lo e/ou ações para produzi-lo.

A seleção das entrevistadas ocorreu através do levantamento e identificação das mulheres no Movimento, sendo reconhecidas durante o trabalho de campo e/ou citadas e indicadas pelas próprias entrevistadas. O objetivo foi criar uma rede de contatos que permitisse um contato prévio das entrevistadas com a pesquisa, a fim de minimizar o efeito da "desejabilidade social”, traduzido pela situação em que a pessoa entrevistada responde com opiniões socialmente desejáveis. (BARRETO, 2008) Nessa seleção do grupo de entrevistadas foi priorizada a heterogeneidade interna das participantes, no tocante à escolaridade, orientação sexual, bairro, atuação, posse, entre outras variantes.

O contato com as jovens aconteceu previamente e a realização de entrevistas aconteceu inicialmente com caráter de teste do instrumento - roteiro de entrevista - para aprimoração do mesmo e como levantamento preliminar dos dados. Foram totalizadas oito entrevistas, realizadas no circuito do centro da cidade, em 
atividades do movimento. Após as entrevistas serem devidamente transcritas, foi construído um banco de dados, e, posteriormente, ocorreu o processo de construção das categorias seguida da análise de seus conteúdos e interpretações possíveis.

Todas as entrevistas contam com a devida autorização das entrevistadas, sob uma preocupação ética, respeitando suas escolhas quanto à forma de divulgação de seu nome neste trabalho. Para elas, foi apresentado um documento da pesquisa que inclui informações referentes ao objetivo acadêmico e social deste trabalho para o seu conhecimento.

\section{As interlocutoras desta pesquisa}

Abaixo temos alguns dados acerca das entrevistadas que optaram assumir sua própria identidade e nomes reais.

Carla Cristina de Jesus Santos ou Kaia na Paz (nome artístico), rapper e b-girl, 23 anos, negra, soteropolitana, solteira, mora com pai, mãe e irmã no bairro Vila Canária, tendo renda familiar de um a três salários mínimos, cursa Pedagogia na UFBA e é cotista, trabalha com projetos educacionais e compõe a banda de rap Munegrale.

Simone Gonçalves Santos, rapper e b-girl Negramone, 25 anos, negra, soteropolitana, lésbica/casada, mora com companheira no centro da cidade, possui renda familiar de um a três salários mínimos, sua família vive no bairro São Marcos, cursa Dança na UFBA e é cotista, trabalha com projetos educacionais e com a banda de rap Munegrale.

Ana Paula Conceição Oliveira, rapper Azevixe, 24 anos, negra, soteropolitana, casada, mora com seu companheiro na Vila do Politeama, sua família é oriunda de Itapuã, e vive com dois a três salários, é pedagoga pela UFBA, pós-graduanda, trabalha como 
produtora da cultura hip-hop, foi vocalista da banda Simples Rap'ortagem.

Eliciana Santos Nascimento, militante do hip-hop Lis, 23 anos, negra, soteropolitana, casada, mora com o namorado no bairro de Ondina, sua família reside no bairro de Periperi, encontra-se sem renda no momento, é comunicóloga pela universidade privada Universidade do Salvador (UNIFACS), estudou sem bolsa de estudos, videomarker e produtora do filme "Hip-hop em quatro vidas”.

Priscila da Costa Lino, b-girl Nayala, 18 anos, negra, soteropolitana, solteira, oriunda do bairro de São Cristovão, não sabe informar renda, cursa ensino médio em escola pública, professora de break no Projeto Escola Aberta na escola pública de seu bairro. Sua mãe era contra seu trabalho com a dança break.

Vivian Quatuni, militante Olhasse, 25 anos, negra, soteropolitana, solteira, mora no bairro Uruguai com os sete irmãos, sendo ela a única filha; ela está sem renda no momento, e conta com a renda da família, entre dois e três salários; possui Ensino Médio e entende que a sua profissão é ser militante do movimento negro pelo Movimento Negro Unificado (MNU) e do hip-hop.

Dina Lopes, rapper Dina, 45 anos, negra, soteropolitana, solteira, mora com a filha única no bairro Sete de abril, cursou Teologia e atualmente cursa Ciência Sociais na modalidade EAD. É artesã de joias sem renda fixa e uma das primeiras rappers da cidade na banda Último trem; faz parte também do movimento rastafári ${ }^{31}$ e do movimento de economia solidária.

Mônica Reis, grafiteira Mônica, 28 anos, negra, soteropolitana, casada e mãe, mora no bairro São Caetano com marido (grafiteiro) e duas filhas. A renda do casal chega a quatro salários mínimos,

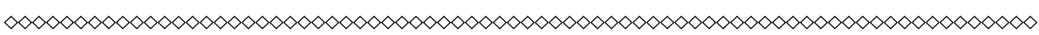

31 Entendo o movimento rastafári como um movimento que segue a filosofia "rasta", reproduzida pelas mensagens da música reggae e simbolizada pelos cabelos rastafari, como aspectos identitários religiosos e de posicionamento político de afirmação negra. Um dos maiores responsáveis pela divulgação desta filosofia foi o músico Bob Marley. 
possui ensino médio completo, trabalha no projeto "Salvador grafita" e tem reconhecimento internacional do seu trabalho.

Como se pode perceber, há entre elas uma heterogeneidade interna reconhecida pelas identidades de mães, lésbicas, solteiras, estudantes, graduadas, professoras, e outras entre as participantes. Essa diversidade se revelará na riqueza dos dados de pesquisa a serem analisadas sobre as convenções de gênero no hip-hop soteropolitano. 


\section{HIP-HOP É TAMBÉM COISA DE MENINA ? ${ }_{32}$ convenções de gênero e mulheres jovens no movimento hip hop soteropolitano}

Este capítulo tem por objetivo analisar as convenções de gênero que orientam as concepções de feminilidade e de masculinidade forjadas a partir de experiências vivenciadas no âmbito do movimento Hip-hop soteropolitano, na perspectiva das mulheres militantes. Dessa forma, serão realizadas duas tarefas: a de compreender como se expressam as convenções de gênero a partir da militância dessas mulheres, e como essa militância transforma ou reforça essas convenções de gênero nesse movimento e na sociedade.

Convenções de gênero são aqui compreendidas como

o conjunto de valores e ideais relativos ao imaginário sexual disponíveis na cultura e compartilhados, a partir dos quais os seres sociais pautam as suas ações e concepções de mundo, reproduzem e recriam estas mesmas convenções e suas práticas. (BONETTI; FONTOURA, 2007, p. 68)

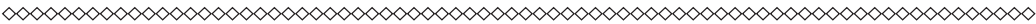

32 Expressão colhida no nome do grupo de mulheres do movimento Hip-hop, que serviu como uma chave analítica, a qual tomei de empréstimo para uso no debate das convenções de gênero na pesquisa. 
Sendo assim, compreendo o universo do Hip-hop como um espaço em que tais convenções estão presentes, nas mais diversas manifestações, conforme aponta Angela Maria de Souza (1998). Em sua pesquisa etnográfica, a autora aponta que o hip-hop tem regulamentações de códigos verbais, gestuais e de vestuário que são linguagens possíveis de serem compreendidas apenas por iniciados nas artes do movimento. O que também foi apontado por Fernanda Noronha (2007) em sua pesquisa etnográfica sobre o hip-hop paulista, ao afirmar que ser membro de um grupo hip-hop implica em compartilhamento de características como faixa etária, gostos musicais, percursos urbanos, circuito de amizade, e até ter origem nas "quebradas", como é chamada a periferia na "gíria" do Movimento, entre outros termos.

Nas observações em campo e no interesse em registrar as experiências das jovens hip hoppers soteropolitanas, oportunizei contatos com redes de movimentos de mulheres e jovens do movimento Hip-hop. A partir da observação das convenções encontradas, pode-se perceber o que se entende ser os modelos de feminilidade e de masculinidade e seus repertórios de ação no hip-hop. Para esse trabalho foram escolhidos casos vinculados aos elementos artísticos do hip-hop, entre eles, o rap, grafiti, break e militância, relatados pelas jovens entrevistadas.

Nesse sentido, as falas e ações das entrevistadas são traduzidas em dados etnográficos importantes que permitem a análise de gênero sob as relações de poder voltadas para os aspectos relacionados à masculinidade e a feminilidade nesse movimento, pois segundo Maria Naomi Castilho Brito (2001, p. 292): “A partir da perspectiva de gênero, têm sido priorizadas as investigações históricas e sociológicas que procurem incorporar as dimensões do masculino e do feminino na análise de forma relacional". Compreendo que essa perspectiva de gênero determina relações de poder que estão em constante negociação e podem alcançar 
distintas configurações a depender do local e dos grupos em questão.

Porém, vale ressaltar que esse olhar de gênero sob essas convenções terá uma interpretação baseada em um comprometimento feminista. Cecilia Sardenberg (2002, p. 90) explica que essa proposta política - científica feminista - tem como base "[...] um saber alavancado em uma perspectiva critica feminista de gênero". Contudo, para alcançar esse objetivo são necessários critérios que envolvem a postura da pesquisadora em campo, sua relação com a comunidade acadêmica e com o universo pesquisado, além da própria investigação etnográfica. (BONETTI, 2007)

O posicionamento para um feminismo jovem interage com a multifacetada realidade e visualiza questões específicas da juventude e das jovens mulheres, com suas diversas subjetividades. Subjetividades essas vinculadas de forma marcante à sexualidade e à negritude diante da identidade de jovens negras que afirmam questões específicas a suas demandas e pautas de sujeitos políticos. (ZANETTI; SOUZA, 2009; ÁVILA, 2000)

Para tanto, a partir da busca pela compreensão acerca das convenções de gênero no movimento Hip-hop soteropolitano, o foco é compreender se e como hip-hop também é coisa de menina, conforme apontaram minhas interlocutoras. Essa questão foi alvo das próprias hip hoppers locais quando realizaram, em Salvador, no ano de 2010, o Seminário ${ }^{33}$ Lugar de mulher é também no Hip-hop. ${ }^{34}$

O objetivo desse evento foi o de reunir mulheres de atuação no hip-hop na cidade para propor que juntas fomentem a construção

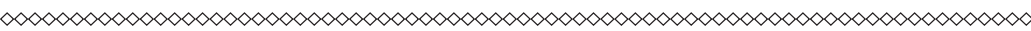

33 Contudo, esse seminário teve atenção especial no trabalho de campo, sobretudo por ter sido o espaço em que realizei registros etnográficos e apliquei as últimas entrevistas em campo. Esse evento foi produzido coletivamente pelo Núcleo Hip-Hop Coisa de Menina, com apoio do Fórum Estadual de Juventude Negra e a Posse de Conscientização e Expressão (PCE).

34 Referência ao slogan feminista que reivindica o espaço para as mulheres na política, seja na política institucionalizada ou em experiências diversas, que relacionem mulheres e política como espaços privilegiados de poder. 
de mecanismos para a legitimação, profissionalização e fortalecimento das mulheres do hip-hop local. Além disso, há uma ligação com uma articulação regional que visa discutir a participação dessas mulheres no I Encontro de Gênero e Hip-Hop Norte e Nordeste ${ }^{35}$ e também a necessidade em dar continuidade a realizações dos encontros estaduais de gênero.

Por isso, este capítulo utiliza o título "Hip-hop é também coisa de menina", que se remete ao Núcleo Hip-hop Coisa de Menina, afinado ao objetivo desta proposta de investigação. $\mathrm{Na}$ fala das interlocutoras esteve corrente a preocupação em refletir acerca do que convém ser do feminino e do masculino na sociedade e também no hip-hop, a partir de suas críticas sobre essas fronteiras e novos ajustes dessa relação.

Portanto, a pergunta "Hip-hop também é coisa de menina?" permitiu o contato com ideias e experiências das mulheres e homens, compartilhando reflexões acerca das concepções de feminilidade e de masculinidade ensejadas no interior do movimento Hip-hop soteropolitano. Com o olhar da perspectiva das jovens hip hoppers, foram priorizadas a atenção sobre pontos de vista e aspectos que explicitassem suas visões de mundo e desafios para as mulheres adentrarem no universo hip-hop.

Em Salvador, há uma série de mulheres que registram sua presença nesse segmento do movimento social jovem, de forma a demarcarem seu espaço, como a influenciarem em ações e pautas do mesmo. Entretanto, essa relação não é exatamente harmônica em se tratando das noções que identificam e diferenciam aspectos entre feminilidade e masculinidade forjadas dentro do movimento. Ou seja, é a partir das convenções de gênero vivenciadas no interior do movimento que se criam modelos com regras,

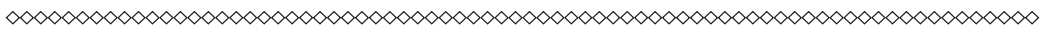

35 Segundo Mara Asantwaa, esse era um dos objetivos do seminário, o de articular mulheres para ir a esse I Encontro de Gênero e Hip Hop Norte e Nordeste, entretanto, este não foi alcançado devido à desarticulação do próprio encontro. 
limites e novas configurações, que por sua vez definem ou identificam o que convém ser coisa de ser menina ou coisa de menino para integrantes do hip-hop.

Figura 1 - Abertura do Seminário Lugar de mulher é também no Hip-hop

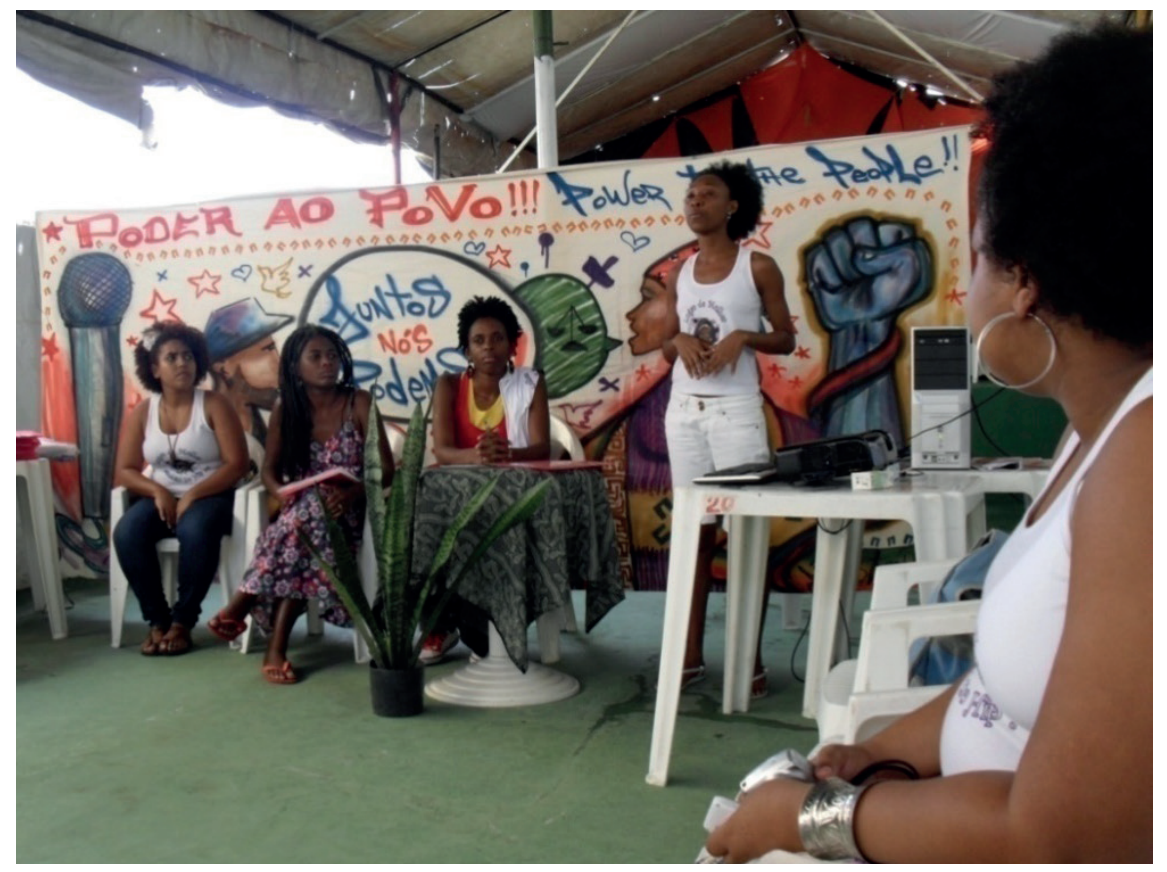

Fonte: produzido pela autora (ago. 2010).

Composto apenas por mulheres, o núcleo Hip-hop Coisa de menina é resultado de uma articulação recente, interessada em reanimar o debate de gênero dentro do movimento Hip-hop soteropolitano e também nos âmbitos estadual e regional. É importante frisar que essas mulheres militantes desse específico grupo são integrantes do movimento com longa experiência de articulação no movimento de mulheres do Hip-hop, pertencentes aos primeiros grupos da cidade, inclusive responsáveis pela realização dos três primeiros encontros estaduais de 
mulheres e hip-hop, e por inúmeras reuniões de mulheres nesse movimento em Salvador, além de integrarem núcleos exclusivos de mulheres em posses mistas de hip-hop, a exemplo do Núcleo de Mulheres da Rede Aiyê Hip-Hop ${ }^{36}$ e do Núcleo de Mulheres da Posse Consciência e Expressão (PCE) ${ }^{37}$

Para contextualizar o movimento de mulheres do hip-hop até o momento do Seminário citado acima, é apresentado um levantamento panorâmico sobre suas ações em Salvador, o qual revela uma intensa articulação política do movimento e das hip hoppers ao priorizarem "as mulheres" como pauta. Para conhecimento, são exibidos registros que pretendem fazer uma breve retrospectiva panorâmica do movimento de mulheres hip hoppers.

A experiência do movimento com os encontros de gênero e hip-hop, ocorridos entre os anos de 2003 a 2005, promoveu uma mudança crucial no papel de atuação feminina no hip-hop baiano. O resultado foi de contribuições no avanço de questões como reconhecimento e luta pelo espaço das mulheres no hip-hop. Esses encontros destacam um aspecto identitário do hip-hop soteropolitano e baiano no que diz respeito à prioridade de espaço para a discussão de gênero e sobre as mulheres, pois não foram encontrados registros de encontros que reunissem tais características em outros estados brasileiros.

No intervalo dos, praticamente, últimos cinco anos, de 2006 a 2010, ocorreu um recolhimento ou diminuição de ações específicas do movimento de mulheres e geral do hip-hop em Salvador, em relação aos anos anteriores de intensa agitação no cenário hip-hop, constantemente visto em suas intervenções pela cidade. Nesse primeiro período, nos anos de 1996 a 2005, o hip-hop

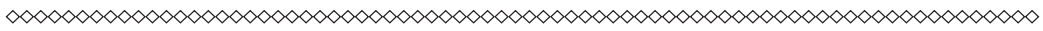

36 Um grupo específico de mulheres dentro de uma Rede em que reúne vários grupos mistos (homens e mulheres) do hip-hop, chamada Rede Aiyê Hip-Hop.

37 Um grupo específico de mulheres dentro da Posse Consciência e Expressão (PCE), que é uma posse mista e uma das integrantes da Rede Aiyê Hip-Hop. 
realizava encontros estaduais, nordestinos, e até nacionais, a exemplo do "Painel de Direitos Autorais". ${ }^{38}$ Esses encontros reuniram jovens da capital e do interior para discussões em torno das questões de organização do movimento e de fomento dos seus elementos artísticos. Na realidade, há uma nova conjuntura a partir de novas formas de articulações em outros espaços e estratégias de ações do movimento.

Este período mais recente culminou em uma desarticulação de uma grande parte do movimento soteropolitano, e um segmento específico, e de maior ação em Salvador e no Estado, até então tratando particularmente da Rede Aiyê Hip-Hop. Essa rede continua ativa, mas em articulações mais tímidas ou mesmo fechadas ou em espaços virtuais (lista de e-mail do grupo), distinta das intensas atividades que aconteciam nos primeiros anos após o desmembramento da Posse Ori, no centro da cidade.

No que trata diretamente de realizações de atividades com caráter de reunião ou encontro, de espaço para debate, discussões e construções de pautas direcionadas para o movimento de mulheres do hip-hop, mesmo que de âmbito local, ocorreram eventos pontuais diante da desarticulação dos próprios núcleos de mulheres de distintas posses. Esse cenário é resultado de uma desarticulação de alguns segmentos do movimento Hip-hop e de outros movimentos sociais. No que se trata de mulheres do hip-hop, pode-se dizer que houve um enfraquecimento dos segmentos do movimento que priorizavam o estímulo à participação das mulheres no hip-hop e a inserção dos debates sobre gênero em suas atividades.

Houve o acompanhamento de reuniões do Núcleo de Mulheres da Rede Aiyê Hip-Hop durante algumas oportunidades. Era

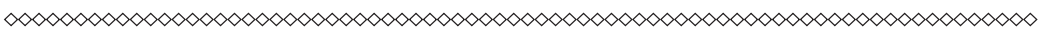

380 movimento Hip-hop baiano também se antecipou às articulações nacionais, impulsionado a formação do "I Painel de Direitos Autorais", em 2006, que contou com a presença de especialistas em direitos autorais e de gravadoras que discutiram com o público sobre o assunto, contando com a participação de Gaspar, representante do grupo de rap paulista Z'africa Brasil. 
corrente o grupo ter dificuldades para realizar seus encontros sob justificativas em torno da falta (falha) de comunicação, o escasso dinheiro para o transporte e da desmotivação pelo esvaziamento dos espaços de reunião. Era comum o atraso em torno do horário das reuniões, como o reduzido número de membros presentes. Nos últimos encontros, era perceptível o enfraquecimento do Núcleo de Mulheres da Rede Aiyê Hip-Hop.

\begin{abstract}
A situação tornou-se mais complicada após o cancelamento das reuniões abertas da Rede Aiyê Hip-Hop, por volta do ano de 2006 e 2007, que aconteciam na Praça do Passeio Público ${ }^{39}$ reunindo integrantes do movimento, parceiros, convidados e curiosos transeuntes neste local, no centro da cidade. Esse espaço misto era um local de encontrar pessoas e planejar ações específicas que envolviam os núcleos que compunham a Rede. Esses núcleos eram: Núcleo de Mulheres, Núcleo de Grafite e Núcleo de Comunicação. (Diário de campo, 16 ago. 2010)
\end{abstract}

Nos anos de 2006 a 2011, o movimento de mulheres do hip-hop não se intimidou pelas barreiras e realizou pontuais atividades específicas das hip hoppers, a exemplo do curso de inglês "I have a dream" e do curso de formação de b-girls, nos respectivos anos de 2007 e 2008. Ambas ações exclusivas do Núcleo de Mulheres da Rede Aiyê Hip-Hop e parcerias.

O curso de inglês "I have a dream" ocorreu durante o ano de 2007. Consistia em um curso de inglês básico voltado para integrantes do movimento Hip-hop e de outros segmentos do movimento Negro. Foi uma iniciativa do Núcleo de Mulheres da Rede Aiyê Hip-Hop e parcerias do movimento de mulheres, voltado para um público estudantil composto por homens e mulheres ligados a movimentos sociais e ao hip-hop, bem como estudantes da UFBA.

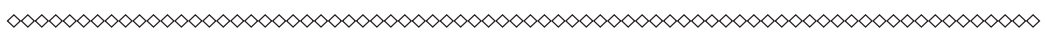

39 A Praça do Passeio Público, no centro da cidade, foi o cenário para muitos movimentos culturais em Salvador, além do Hip Hop, muitos movimentos culturais de música e teatro. 
O curso de formação de $b$-girls,${ }^{40}$ com duração de três meses, no início de 2008, foi o primeiro curso de break para mulheres na América Latina. Foi promovido pelo Núcleo de Mulheres da Rede Aiyê Hip-Hop em parceria com o Fundo Angela Borba de Recursos para Mulheres, ${ }^{41}$ e do Centro de Estudos Afro-Orientais (CEAOUFBA). A turma era formada por 25 mulheres jovens, de 11 a 30 anos, oriundas de bairros populares de Salvador, as quais tiveram, durante o período de janeiro a abril, uma iniciação nas técnicas e estilos básicos da dança de rua em paralelo a oficinas temáticas sobre gênero, raça e sexualidades. O objetivo foi incentivar a formação de um maior número de mulheres dançando break, as novas $b$-girls.

Além desses cursos ocorreu, em 2008, o III Encontro de grafiteiras, que reuniu mulheres brasileiras e latinas. Nesse período, no ano de 2009, também ocorreu o I Encontro de Jovens Feministas Negras em Salvador, no qual muitas hip hoppers soteropolitanas e de diferentes estados brasileiros compareceram para contribuírem nas atividades do evento.

Outro importante evento ocorrido em Salvador foi o festival de contracultura feminista Vulva La Vida - necessariamente feministas, necessariamente inconvenientes -, realizado de 19 a 23 janeiro de 2011 e organizado por uma rede de coletivos e de garotas que se colocam contra o que é chamado "feminino" na sociedade. O festival reuniu jovens de diversos estados brasileiros, em maior parte adeptas ao estilo rock da contracultura feminista, estando também presentes as hip hoppers. Já não era mais período

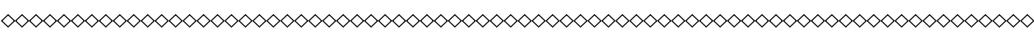

40 Endereço eletrônico do blog do curso: <http://www.cursobgirls.blogspot.com/>.

41 O Fundo Angela Borba de Recursos para Mulheres foi criado em agosto de 2000, a partir do Seminário internacional Mulheres, responsabilidade social e recursos financeiros, ocorrido no Rio de Janeiro para dar apoio a projetos brasileiros. É o primeiro fundo de investimento social brasileiro que direciona recursos exclusivamente para organizações de mulheres, sendo um exercício de captação e distribuição de recursos para atividades de investimento social na promoção e defesa dos direitos humanos das mulheres. Informações disponíveis em: <http:// pt.wiserearth.org/organization/view/090cc8836f45c0db26e306213ad2409a>. 
de trabalho de campo, mas ocorreu o acompanhamento da oficina de hip-hop com os elementos do break e do rap inseridos nas atividades do evento.

Em sua programação, o festival contou com exibições de filmes temáticos sobre mulheres e sexualidades, bate-papo sobre a bicicleta como meio de transporte, além de várias oficinas direcionadas exclusivamente para mulheres com os temas mais diversos, como vegetarianismo e alimentação vegana, moda e estética, feminismo e pornografia, wendo (luta de defesa feminina) e duas oficinas específicas envolvendo elementos do hip-hop. ${ }^{42}$

A oficina de dança de rua e de rap foram as primeiras, e ocorreram no dia 20, no turno da tarde, ministradas pela rapper e $b$-girl Negramone com a presença da também rapper e $b$-girl Carla Kaianapaz, também djeia, pois ficou responsável pelo beat box,,$^{43}$ conforme registrei nas minhas notas de campo:

No salão sem cadeiras que reunia as jovens participantes da oficina de rap e break, mulheres de diferentes vertentes poderiam ser identificadas por estilos musicais. Havia roqueiras com suas roupas rasgadas com blusas de banda, havia metaleiras que usavam roupas pretas e cabelos longos, mulheres de cabelo curto, corte moicano e até carecas, - estas eram as punks que exibiam maquiagens fortes, piercings e tatuagens.

A proposta do festival era reunir mulheres da contracultura, e essas jovens, muitas que não gostavam de hip-hop, algumas que não conheciam, ou que até ouviam um pouco de rap, estavam

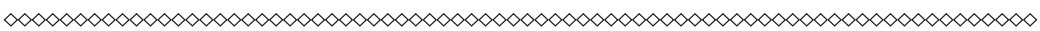

42 A oficina de graffiti e arte urbana ocorreu no dia 21, pela manhã, na sede da "Cozinha vegan" localizada no Pelourinho. Essa atividade teve continuidade no final da tarde, com o graffiti em bairros da cidade, e foi ministrada pela grafiteira Kátia, também conhecida por Sista K.

43 Beat box é o som produzido na boca, sem o uso de equipamentos musicais, produzindo a batida do rap, o qual a djeia ou rapper faz como base para que outra pessoa(s) cante(m), rimando em cima da batida. Beat box é apresentado por "bate lata" no trabalho sobre rap feminino em Campinas, de Mariana Semões de Lima (2005), porém, nesse caso, as rappers não faziam som com sua própria boca, mas "batiam com as mãos em uma lata". 
nessa oficina se abrindo para o hip-hop instigador de críticas vorazes a partir do rap, inicialmente, e, posteriormente, ao break.

Negramone começou a oficina falando um pouco sobre a história do hip-hop e de seus elementos, e depois mostrou como se organiza a métrica de uma rima, pedindo que Carla marcasse o beat da música. Depois a turma se dividiu em grupo para que produzissem sua própria música e letra de rap. O resultado foi um clima descontraído, produzindo mensagens de protesto em torno da liberdade do corpo das mulheres e a chance de muitas mulheres se permitirem ao envolvimento com o rap, especialmente para jovens que nem desse estilo gostavam.

No segundo momento, ao som de suas próprias músicas, cantadas pelo grupo que compôs e pelo restante da turma, as jovens fizeram uma roda de break que permitiu as formas mais variadas de dança apresentadas uma por uma no centro do círculo. (Diário de campo, Salvador, 20 jan. 2011)

Eventos como esses citados acima ajudam a contextualizar a discussão acerca das mulheres no movimento Hip-hop e sua percepção sobre o que é "coisa de menina" neste. Essa questão foi diretamente tratada pelas hip hoppers no Seminário Lugar de mulher é também no hip-hop, e será foco de atenção a seguir, como um espaço especial de observação das expressões das convenções de gênero a partir da militância das hip hoppers.

O trabalho de campo contou com o acompanhamento integral da realização do seminário citado acima, que durou dois dias, e teve início no sábado, dia 14 de agosto de 2010, reunindo aproximadamente 40 pessoas, em sua maioria mulheres negras e jovens, mas também crianças e homens. Esse evento foi realizado após duas remarcações de datas anteriores, até que finalmente se confirmou sua realização, não sendo divulgado o motivo de seus adiamentos.

Em meio à plateia do evento, pode-se sentir um clima de curiosidade, sobretudo das jovens que ali chegaram. Entre as 
perguntas curiosas envolvendo o cenário hip-hop, destacou-se: o que iria mesmo acontecer naquele espaço? Seria um show? Uma festa? Uma aula? Uma mesa de debate sobre algum tema relacionado ao hip-hop?

Não se sabia como seria a organização daquele espaço promovido pelas hip hoppers. Elas estavam interessadas em conversar, discutir temas diversos acerca da presença das mulheres no hip-hop, em apresentar algumas personalidades com trabalhos em torno dos quatro elementos do hip-hop e que compartilhassem experiências em projetos vinculados às suas artes e militância.

Vale ressaltar que a presença dos homens - em minoria dessa vez, diante do caráter de um encontro específico do movimento de mulheres, mas de abertura para participação dos homens foi priorizada nas mesas de debate com a presença de parceiros convidados a relatar sua experiência de colaboração com os trabalhos e ações das mulheres no movimento. Em especial, as mesas do Seminário contaram com a presença de homens e DJs do cenário do movimento Hip-hop de Salvador. O primeiro deles, o DJ Bandido, com marcada contribuição por incentivos à produção feminina no rap e, o segundo, DJ Jarrão, que compõe o grupo de rap chamado Audácia, ex-Neuróticas, composto até então apenas por mulheres. Também havia reduzida presença de homens na plateia.

O Seminário teve início com uma fala das rappers, Cintia Neurótica, da banda Audácia, sobre a importância do evento e sobre o Núcleo que o produzia. A rapper Mara Asantawaa também deu as boas-vindas às participantes e colocou sua preocupação sobre as dificuldades das mulheres se articularem no hip-hop, mesmo essas tendo relevante participação em determinados elementos. Dado por aberto o seminário, as rappers apresentaram de forma entusiasmada a programação. 
A mesa de abertura teve como tema "Um breve histórico sobre a atuação da mulher no Hip-hop baiano e o cenário atual”, e foi composta pelas rappers Dina Lopes (ex-Último Trem) e Simone Gonçalves (Negramone), da banda Munegrale. A contribuição das rappers trouxe o relato de suas experiências femininas no hip-hop. Elas traçaram um breve histórico do movimento de mulheres dentro do movimento Hip-hop baiano, ao destacar em, sobretudo, as transformações por que passaram mulheres após entrar no Movimento.

Nas falas de ambas as palestrantes estavam presentes símbolos de força, coragem e poder que identificavam as convenções de gênero acerca do modelo de feminilidade que se destacava em diversas expressões, a exemplo da atitude de subir no palco, mostrar sua música, afirmar sua identidade de mulher, negra, lésbica e outras. Entre elas, foram destacadas questões em torno do contato e sua inserção no hip-hop, e o envolvimento com seus elementos, sob críticas que se aportavam a um modelo masculino de atuação, como vestir roupas folgadas, falar no estilo "malandro", cantar com uma mão no microfone e a outra como que pegando no pênis. ${ }^{44}$

O hip-hop tem aspectos que o caracterizam como um movimento masculinista diante da majoritária presença de homens que expõem determinados símbolos, modos de comportamento, linguagens e entre outros aspectos que são reconhecidos pelo estilo (modelo) "hip-hop de ser".

Dina, uma das primeiras rappers a cantar na capital baiana quando integrante da banda Último trem, durante os anos de 1996 a 2003, foi questionada sobre a inserção das mulheres no Movimento e nos elementos do hip-hop e sobre a relação para com os homens, afirmando que:

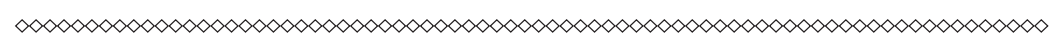

44 As hip hoppers fazem imitações, como sátiras, mostrando a forma de cantar de muitos rappers. Elas brincam "Será que têm medo de sair?" 
É uma relação conflituosa, porque é uma relação de ocupar espaços, porque a partir do momento em que os homens já estão culturalmente inseridos, que eles têm mais poder do que nós mulheres, é uma relação difusa mesmo, você tem que chegar e dizer para ele, 'não é assim! Esse espaço é nosso!'.

A fala de Dina expõe a percepção acerca das expressões das convenções de gênero no hip-hop. Para tanto, é a partir das falas das hip hoppers que se destacam as experiências das mulheres em seu envolvimento com os elementos do hip-hop e seu diálogo com as convenções de gênero no Movimento.

Nesse sentido, é possível elencar algumas questões que podem orientar a compreensão em torno desse debate. Quais são as convenções de gênero identificadas dentro do hip-hop, que se diz um movimento contestatório? Como se constituem os modelos de feminilidade e masculinidade no hip-hop? Como são expressas essas regras e limites para que se distinga o que pertence ou não ao masculino e ao feminino? Para essas e mais algumas questões que surgiram no intuito de identificar as convenções de gênero no hip-hop, foram consultadas algumas hip hoppers soteropolitanas que compartilharam experiências em torno de sua inserção e permanência no movimento.

A partir das particularidades do campo são destacados dados fundamentais que auxiliam na compreensão do olhar sob a militância das mulheres no campo do movimento social Hip-hop em Salvador. São casos selecionados que expressam as convenções de gênero encontradas e que aguçam a percepção de como essa militância feminina transforma ou reforça essas convenções de gênero nesse campo.

Das experiências compartilhadas pelas mulheres hip hoppers, foram selecionadas quatro relacionadas aos elementos rap, grafite, break e militância. 


\section{Uma rapper: salto alto $X$ tênis, minissaia $X$ calça larga}

Como estilo musical do hip-hop, o rap é o elemento de maior destaque entre suas expressões, criado a partir de letras politizadas sob diferentes estilos de batidas, descrevendo e envolvendo o cenário cultural e político por onde passa. A sigla RAP significa a junção do "ritmo e poesia" (Rhythm and Poetry - expressão em inglês) e é muitas vezes improvisado por DJs (Disk Jóqueis) e MCs (Mestre de cerimônia).

Esse estilo musical nasceu em Nova York sob influências de diversos estilos, entre eles, soul, jazz, blues e funk, além de outras novidades oriundas da Jamaica. O que esses estilos têm em comum é que todos são expressões da musicalidade negra. (SOUZA, 1998) Entretanto, Sansone (1997) destaca que eles não podem ser entendidos como homogeneizados e massificados, pois têm diferentes e específicos registros de tempo e espaço. Porém, o autor identifica os estilos reggae, funk e o hip-hop como retrato das juventudes globais, criados pela mídia e reconhecidos pelas ciências sociais.

As expressões desses gêneros musicais foram relevantes para a politização acerca da identidade negra, de imigrantes e de pobres, e instrumentos de problematização das condições de vida da população negra em especial, e também de outros grupos pelo mundo. Segundo Wivian Weller (2005), o hip-hop surge com uma concepção de articulação e combate contra o racismo e o preconceito.

Existem vários tipos de rap, em sua maioria inicialmente difundidos nos Estados Unidos, e posteriormente expandidos pelo mundo, sendo que entre eles pode ser citado o rap gângster, vinculado à criminalidade e do qual o movimento se coloca de forma 
contrária. No Brasil, é mais comum o rap militante, de discusso engajado, entrada no movimento social Hip- hop.

Quem canta rap é rapper e esses são homens ou mulheres. Ambos os sexos têm usado essa arte como uma forma de falarem sobre si mesmos e sobre suas inquietações. Entretanto, o espaço do rap tem se configurado pela sua masculinização, um tanto intimista diante de eventuais empurrões, brigas e rodas de bate- cabeça. Assim, como mostrou a pesquisa de Fernanda Noronha (2007) no ambiente do movimento Hip-hop paulista nesta primeira década do século, o cenário soteropolitano compartilha a reduzida presença feminina nos shows de rap, estando as mulheres, em sua maioria, acompanhadas ou protegidas em grupinhos.

A presença das mulheres na plateia de shows de rap para a apresentação de uma rapper no palco pode ser conhecida através do aprofundamento da experiência de Dina como rapper. Sua atuação teve início no rap ao integrar a banda Último trem, quando era a única mulher a participar da sua formação. Ela relata sua vivência de mulher e rapper no movimento Hip-hop:

Tipo cantar rap, para você ser vista como mulher você tinha que se vestir como os homens, usar jeans, usar tênis. Eu particularmente não gosto de usar tênis, eu particularmente não gosto de usar calça folgada, coisa de homem, eu não gosto. Eu gosto de usar vestido, sainha, entendeu, então isso já era uma oportunidade, quando eu me vestia para cantar e eu ia de um salto alto, tinha questionamentos, tinham olhares.

Em sua fala na mesa de abertura do Seminário Lugar de mulher é no Hip-hop, Dina defendia a afirmação de aspectos que identificavam as mulheres que queriam cantar rap como mulheres, com seus adereços, que independente de suas orientações sexuais 
faziam parte do que as diferenciavam dos homens. Ela se coloca contra a convenção que imputa masculinização da atuação para o reconhecimento dessa arte feita por mulheres.

Dina conta que no primeiro momento de organização do movimento em Salvador, quando Posse Ori, as mulheres ainda não tinham muita crítica sobre sua condição de mulheres, e reproduziam um imaginário de que havia um modelo de ser rapper a ser obedecido, como condição para se obter reconhecimento de sua produção e performance artística. Esse modelo se aportava nas referências masculinas dos rappers estadunidenses, a exemplo de $2 \mathrm{PAC} .{ }^{45}$ Assim, os homens rappers, negros, apresentavam um estilo rapper e também hip hopper de ser por um estilo de vestir.

Foi esse estilo de vestir, hip hopper, que a rapper Dina contestou, por dialogar com uma das convenções de gênero acerca da masculinidade e também da feminilidade no hip-hop, em torno do imaginário de que ele e o rap são coisas de menino, de homem. É o que nos explica Souza (1998), quando descreve que o rap é um estilo musical associado à marginalidade, vindo do gueto e do negro, que encontra inspiração em meninos de rua, presidiários, times de basquete ou futebol (no caso brasileiro) que inspiram referências ao popular.

Esse modelo tradicional de como ser um rapper obedecia à perspectiva de masculinidade composta por itens imprescindíveis como calça folgadas, bonés, tênis grandes e coloridos, longas e folgadas blusas e camisetas, de preferência que exibissem determinadas marcas famosas, a exemplo de Adidas, Nike, Mizuno e outras de grande circulação internacional, e com referência ao "inglês", que remetesse ao hip-hop dos Estados Unidos. Realmente esse era o estilo promovido por rappers estadunidenses, divulgados especialmente em canais de televisão musicais, a exemplo da MTV

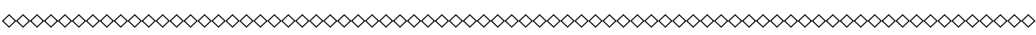
45 Famoso rapper estadunidense assassinado em sua comunidade por um integrante de uma gangue rival. (SOUZA, 1998) 
(Music Television) e dos grandes rappers divulgados na mídia comercial.

No hip-hop soteropolitano - e em geral -, é bastante comum encontrar jovens adeptos do estilo e da moda hip-hop estadunidense. Muitas vezes, a impressão sobre esses jovens é de uma incoerência, devido à realidade financeira da classe popular em que vivem em relação às marcas caras e exibição de etiquetas, mesmo que sejam peças falsificadas - sendo que alguns não são -, mas, sobretudo, pelo próprio clima quente da capital baiana em sua maior parte do ano.

Segundo os (as) militantes, isso ocorre porque muitos obedecem a uma lógica do hip-hop como produto da indústria cultural, bem distinto e afastado do que seria o hip-hop enquanto movimento social. Porém, enquanto alguns segmentos do hip-hop soteropolitano o reproduzem, outros têm uma crítica extrema sobre esse estilo.

Integrantes dos grupos pertencentes à Rede Aiyê Hip-Hop discutiam sobre as roupas de hip-hop estadunidenses usadas pelo hip hoppers soteropolitanos e defendiam o uso de sandálias de couro e chapéus de palha, a fim de resgatar a história dos contadores de história dos griôs africanos e dos repentistas nordestinos com suas rimas e críticas sociais, de forma sátira e cômica, ao embolarem ritmo e poesia, compartilhando a fórmula do rap e da embolada.

Como resposta a este estilo comercial, seus elementos eram adaptados ao clima quente local e à linguagem verbal e corporal do nordeste brasileiro, inclusive em suas letras e performances no rap. Como moda alternativa do hip-hop local, o casal de dançarinos de rua, Tina e Ananias, criam roupas para b-girls e b-boys, adaptando a prioridade de uma roupa leve e confortável para dançar ao estilo hip hopper soteropolitano. Tina descreveu a experiência da grife de hip-hop, que realizou desfiles no Pelourinho em atividades do movimento durante sua 
participação em uma das mesas do Seminário Coisa de Menina. Ela contou que as roupas de hip-hop eram caras e pouco acessíveis aos jovens, e que as peças por eles trabalhadas são encomendadas por preços acessíveis ao público-alvo. (Diário de campo, 2010)

A inserção das mulheres na arte musical do hip-hop, o rap - que chega a ser conhecido até por hip-hop -, provocou certa mudança no que vinha a ser estabelecido a um gênero específico, à medida que elas formataram uma espécie de diálogo entre símbolos masculinos e femininos em volta do cantar rap. Saias, minissaias, vestidos e blusas "de alcinha" compunham o figurino das rappers, que subiam no palco e rimavam sob a batida do DJ.

Sapatos de salto alto passaram a ocupar espaços antes exclusivos de tênis coloridos, de cano alto ou baixo. Algumas rappers não abriam mão de sua maquiagem, batom e rímel, adereços nos cabelos e no corpo como turbantes e brincos grandes, pulseiras e penteados que exploravam a beleza negra, a exemplo dos cabelos estilo black power e trançados das formas mais inusitadas. Elas sobem nos palcos demonstrando que o rap também é coisa de menina e tem estilo feminino de performance para cantar, rimar (compor) e interagir com a plateia.

Geralmente, os nomes das bandas e nomes artísticos e de guerra das rappers têm uma conotação de empoderamento, força e luta, a exemplo do nome da banda Áudácia Feminina e da rapper carioca Refem (Revolta Feminina), responsável pela produção do documentário O rap do batom. Refem, como é chamada no movimento, veio a Salvador para participar do Encontro Nacional de Juventude Negra, e articular junto às mulheres do hip-hop soteropolitano a exibição de lançamento deste vídeo em Salvador. De qualquer forma, ela deixou com o Núcleo de Mulheres uma cópia do documentário que trata dos desafios de uma rapper no Rio de Janeiro, a partir de sua própria biografia ao relatar seu contato com o movimento social hip-hop, as impressões de sua mãe para com o rap antes e depois de conhecer as 
produções musicais da filha, as novas perspectivas que o rap deu à sua vida, entre outras questões em torno da sexualidade, amizades e profissionalização. (Diário de campo, 2008)

Contudo, as oportunidades para as mulheres no rap soteropolitano são bastante limitadas diante de duas questões: a primeira, pelo próprio cenário musical da cidade, que desprivilegia o gênero musical rap em favor de uma indústria cultural que produz, sobretudo, estilos como a música baiana, axé e pagode, além de outros estilos mais comerciais, a exemplo do forró. Os espaços para a música rap já são restritos no cenário baiano, mesmo que aconteça numa cena alternativa exclusiva para esse estilo, a exemplo do Programa Evolução Hip-Hop na rádio pública, com uma programação voltada para produção e para o público do gênero musical rap. Esse programa foi resultado de uma articulação entre o Instituto de Rádio e Difusão do Estado da Bahia (IRDEB), juntamente com segmentos do movimento Hip-hop. Mesmo nessa programação, a presença das rappers soteropolitanas é tímida. ${ }^{46}$

Já a segunda questão está mesmo vinculada a gênero, para se pensar o espaço das mulheres no rap no meio específico hip-hop. Há uma espécie de controle e "autorização" para que as rappers apresentem suas produções como que em uma disputa, em um espaço predominantemente masculino, sendo, em especial, o palco e o microfone espaços de poder. Esse controle engloba o comportamento, as roupas e o acesso das rappers, muitas vezes sendo colocado pelos homens como uma espécie de proteção, e que implica inclusive em limites das oportunidades de trabalho profissional. (SILVA, 1995; MATSUNAGA, 2008; GOMES, 2008)

Atrelado à importância das referências femininas no rap, Vivian Quartuni conta sobre as raras oportunidades para a apresentação

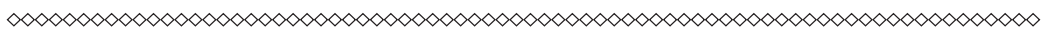

46 A presença das mulheres hip hoppers em geral, independente de um elemento específico, na própria articulação do programa, foi importante, mas temporária, especialmente no projeto, articulação e primeiros momentos. 
das mulheres nesse estilo na cidade. Espaços cada vez mais pontuais para o desenvolvimento desta arte musical do hip-hop pelas rappers,

Deixa eu pensar [risos]. Eu acho que ainda é pouco. Eu não falo nem na questão política, mas eu acho assim até em eventos, se a gente for contar quantos grupos femininos tocam numa noite? Eu só vi um show... onde é que foi?... que foi no Bairro da Paz... no São Caetano e no Bairro da paz, ${ }^{47}$ dois, aliás, que tinham três grupos de homens mistos e três grupos femininos. Então assim... e as meninas todas foram pro palco de saia, a mesa toda do debate foram mulheres que tavam tomando conta. Então assim, são poucos, mas só que essas poucas deixam marcas e deixam história, que depois até... é... até depois as outras pessoas que não acreditaram que as coisas acontecia, porque são mulheres que estão fazendo, é... diz que a...coisa foi bem feita e parabeniza. Acho que são poucas, mas deixam marca, como o encontro de gênero, são poucas, mas deixam marcas e deixam saudade.

Sendo essa uma questão de importância para as hip hoppers, a programação do Seminário Lugar de mulher também é no Hip-Hop priorizou essa discussão e problematizou os desafios das rappers para produzir seus trabalhos. Para compor essa mesa de debate temática, foi convidado um homem, um DJ, o DJ Bandido. Ele é uma personalidade que tem se destacado por seus trabalhos

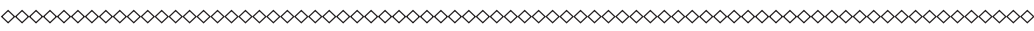

470 evento de Hip-Hop que teve como tema "Hip Hop contra a homofobia" aconteceu em 2007, no Bairro da Paz, e foi liderado pelas mulheres, que estavam não apenas nos espaços das mesas de debate, mas também no palco, contando com a participação de cerca de três bandas de rap compostas exclusivamente por mulheres, sendo duas delas baianas e uma do Piauí. 0 evento ocorreu sob rigoroso esquema de negociação com a escola municipal do bairro e com o grupo "Clã Nordestino", importante segmento do Hip-Hop local e responsável pela articulação dessa produção, que aconteceu na praça principal do bairro, reunindo um número grande de pessoas do local e de outros bairros, sobretudo, jovens. 
de discotecagem e pelo incentivo ao trabalho das rappers em Salvador.

DJ Bandido possui seu próprio estúdio, no bairro do Nordeste de Amaralina, e em inúmeras oportunidades apoiou a produção da rappers. Responsável por incentivar a gravação de um CD exclusivo de mulheres rappers de Salvador, e negociar com as rappers, ainda sem alcançar o resultado esperado, ele aponta como um dos principais problemas para fomentar esse trabalho o próprio comportamento das mulheres. Os registros das produções das rappers são tímidos.

Segundo Bandido, muitas delas desistem de participar da iniciativa porque o namorado disse que ela não devia rimar, ou mesmo que ela não seria uma boa rapper com presença de palco e com entonação para encarar um trabalho como esse. Nesse caso, ele se refere às rappers iniciantes no ramo, ainda inexperientes e em início de carreira. Entretanto, isso também acontece com as rappers de maior tempo no movimento e no próprio rap. São inúmeros os empecilhos que afastam as mulheres de simplesmente registrarem seus trabalhos no hip-hop, estando muito atrelados à questão de autoestima para se expor a críticas, problemas financeiros para dar continuidade a um projeto e, sobretudo, à falta de apoio dentro e fora do movimento Hip-hop.

Como um exemplo a essa fala do DJ Bandido, a rapper e pedagoga Paula Azeviche expõe alguns pontos importantes para pensar a situação do "ser mulher" no rap e no hip-hop. Ela levanta problemáticas que explicam questões específicas compartilhadas pelas mulheres diante de um contexto que compromete sua participação dos espaços e atividades públicas na sociedade e no movimento social.

A primeira delas está vinculada à questão da referenciada participação de outras mulheres no cenário do rap, sendo essa questão recorrente nas discussões entre mulheres hip hoppers, 
e compartilhadas em outros segmentos do movimento social e nos espaços políticos. Como exemplo, Paula cita sua própria experiência e suas motivações para começar a cantar rap a partir da amiga Sílvia, rapper e fundadora de uma das primeiras bandas de rap exclusivamente composta por mulheres, banda chamada de Hera Negra.

Ai um dia Sílvia se retou e começou a rimar, e começou a mostrar os rap, começou a mostrar... dizer que tinha várias letras e a menina apareceu com um monte de letras. E eu achei que podia fazer rap também, quer dizer eu sou bem lenta pra fazer rap. Mas Sílvia foi uma grande inspiração, é uma mulher que depois de Dina D, aí quando eu olho pra trás, é importante que hoje tenha tantas outras mulheres fazendo rap.

Abaixo, segue o registro de um dos shows da banda Hera Negra, em uma de suas formações, no momento, as rappers Negramone, Sílvia e Lica. A banda atuou durante os primeiros anos do hip-hop em Salvador e foi extinta após diversas formações, e não tem registros de suas produções disponíveis para acesso, sendo um dos exemplos no qual se adequa a preocupações expostas acima sobre os não registros das rappers.

Paula e Bandido apontaram a mesma preocupação com relação às dificuldades de permanência e de continuidade dos trabalhos das mulheres no movimento e na produção de suas letras e performances. De acordo com os relatos das experiências das mulheres, é possível perceber como se configuram as características que compõem as convenções de gênero em torno da feminilidade, as quais as mulheres estão submetidas.

Paula usa alguns exemplos para pensar sobre a ausência e permanência das mulheres no movimento, inclusive acerca do tipo de permanência e os principais motivos que afastam as mulheres 
desse meio, a partir do relato de sua própria experiência como a única mulher em uma banda de rap, com maioria de homens. Segundo a rapper, as mulheres

[...] não estão próximas do movimento assim, quanto eu esperava e a gente sabe que é muito difícil. É muito difícil essa permanência, porque a mulher, ela exerce todas as funções na sociedade, a gente está na pirâmide na base quer o homem queria ou não. A gente tem que ser mãe, tem que ser filha, tem que ser mulher, tem que ser dona de casa, tem que trabalhar fora, tem que ter todos os direitos garantidos, tem que pagar as contas, tem que... Sei lá, fazer tudo [...] Até na 'Simples Rap'ortagem', eu sempre tive o papel de fazer a produção da banda, de cuidar daqueles homens todos, de saber 'você tá onde?'. Até hoje é a mesma preocupação e hoje a gente tenta passar todas as atividades com o produtor, mas mesmo assim. Em oito anos de Simples sempre foi assim. E a gente sabe que a gente entra no hip-hop quer fazer as coisas, mas o que acontece, a gente encontra o movimento desestruturado, a gente quer organizar, a gente quer arrumar a casa, a gente que deixa tudo limpo e aí vai. Os processos vão engolindo a gente, engolindo, engolindo, quando a gente vê... Uma vez alguém me disse assim que eu tava lamentando a saída de Dina, que Dina parece que saiu do movimento de vez assim. Lógico que ela não vai sair, porque quem conhece ela sabe que ela é a história do movimento. Mas que tava lamentando a ausência de Dina, e alguém me disse assim: 'Dina já é mulher, Dina tem filha, Dina tem que sustentar a casa'. Eu digo: 'Poxa, será que a gente começa tudo isso, sem acreditar que a gente possa algum dia sustentar a nossa casa do hip-hop'. Ela tem uma filha grande, eu acho que ela teve filho muito cedo, teve a filha muito cedo. Enfim, a gente passa por 
todas essas barras, tem que ser abandonada, tem que ser a traída, tem que ser a que realiza os desejos do marido, tem que ser tudo e ainda fazer hip-hop [risos]. Difícil! Do marido, da mulher, 'né', sempre realizando o desejo de todo mundo e ainda ser do hip- hop. E ai [risos].

É interessante notar que, mesmo com determinadas funções de administração da agenda artística atreladas às atribuições do produtor, a rapper que esteve até então como única mulher na banda assumiu a responsbilidade de "cuidar dos homens" desta. Além de cantar, ela também resolvia questões gerenciais referidas ao trabalho de "cuidar" de seus colegas de trabalho, o que reforça as convenções de gênero tradicionais que vinculam essas características ao feminino. A seguir, é direcionada a atenção para como essas convenções de gênero do feminino e do masculino se expressam no grafite.

\section{Maria latinha não, grafiteira!}

Como já mencionado, o grafite foi um dos dois primeiros elementos do hip-hop, juntamente com o break, e consiste nas expressões das artes plásticas do hip-hop por meio de pinturas e desenhos exibidos nos muros da cidade.

A experiência das mulheres no grafite também não se diferencia das rappers. A grafiteira Mônica Reis palestrou em uma das mesas do Seminário Lugar de Mulher é no Hip-Hop. Exibindo unhas coloridas cor-de-rosa choque, que de longe podiam ser vistas, cabelos pintados de tons avermelhados contrastando com sua pele escura, chamou atenção não apenas pela aparência, mas especialmente pela sua fala crítica ao relatar a experiência das mulheres no grafite em Salvador. 
Vale ressaltar, como retrospectiva do movimento de mulheres hip hoppers, que a presença de grafiteiras no hip-hop soteropolitano é relativamente recente, já que essas têm adentrado no movimento a partir dos últimos cinco anos, e, diante dos registros, não participaram das atividades dos encontros de gênero e hip-hop, ou mesmo dos núcleos de mulheres de posses mistas. Esse primeiro período do hip-hop em Salvador, chamado de primeira geração do movimento (FREIRE, 2010), tinha características bastante vinculadas aos diversos segmentos do movimento Negro, inclusive ao próprio Movimento Negro Unificado (MNU) e outros movimentos sociais, a exemplo do movimento Feminista e Movimento de Mulheres Negras, entre outros.

Essa vinculação é que pode justificar o próprio título dos "Encontros de gênero e Hip-Hop", realizados entre 2003 e 2005, quando esta discussão em torno do termo "gênero" não era difundida na sociedade, mas já fazia parte da gramática da militância do movimento de mulheres no hip-hop soteropolitano e baiano, pois os encontros foram regionais e estaduais, nos quais se distinguiam do movimento de outros estados do Nordeste e do Brasil.

Esse primeiro período do movimento de mulheres já apontava uma perspectiva feminista devido às suas pautas vinculadas à preocupação com direitos e políticas públicas para mulheres, mais do que apenas um interesse para com a cultura hip-hop e seus elementos.

O exemplo de Mônica, que se insere no hip-hop em um segundo momento do movimento, é um relato interessante, pois demonstra questões que envolvem a inserção das grafiteiras nas artes plásticas do movimento. A arte de grafitar tem como ferramenta uma lata de spray, juntamente com muita disposição para enfrentar sol, chuva, grandes caminhadas e negociações à procura de espaços e oportunidades para pintar, além de inspiração para 
o trabalho. Entretanto, para as grafiteiras, os desafios são maiores do que esses, como relata Mônica:

Desde que eu comecei a grafitar e a participar de encontros, essas coisas assim, o que eu ouço falar de meninos falando sobre mulheres, fala de mulher que quer ser grafiteira, chama de 'Maria Latinha', mulher no hip-hop 'Maria Microfone', cada um, eles são apelidos para as mulheres, então acha que não é capaz, e faz porque sempre tem que ter um homem, ou tá fazendo porque acha que gosta de alguém, ou quer pegar alguém, então a mulher é muito desvalorizada, muito desrespeitadas por ser mulher em si entendeu? Então para mim essa é a principal dificuldade que nós temos no meio do hip-hop: apelidadas, esculhambadas, acham que somos incapazes, é copiar, é querer fazer uma coisa que a gente não quer, que isso é para homem, e isso não é para mulher, como antigamente, sabe inventa onda, e hoje a gente sabe que lugar de mulher também é no hip-hop, lugar de mulher também é no grafite, é lugar de mulher é lugar de mulher, então para mim é isso.

É interessante observar que as mulheres são geralmente apelidadas por "Maria algum objeto", relacionando o interesse das mulheres a algum objeto de valor estrangeiro ao seu universo de gênero. Os apelidos dados às mulheres no hip-hop relembram outros apelidos atribuídos a elas, a exemplo do "Maria gasolina", vinculando o interesse de mulheres a homens com carros, e também "Maria chuteira", para as mulheres que buscam relacionamentos com jogadores de futebol bem-sucedidos.

O que se pode apreender desse processo de desqualificação das práticas das hip hoppers é a forma como atendem às convenções sociais de gênero, que definem distintos repertórios, valores e símbolos para o feminino e para o masculino. Dessa forma, as 
grafiteiras, quando se apropriam de atributos masculinos - no caso, a latinha de spray -, trasgredindo as regras de gênero tacitamente estabelecidas, sofrem sanções do grupo em forma de desqualificação e desvalorização. Tais sanções instituem processos de produção de desigualdades e hierarquizações de gênero que recaem negativamente sobre o feminino.

A lata de spray, o microfone, o carro e a chuteira são hoje objetos acessados pelas mulheres, mas simbolicamente objetos do universo masculino. Nesse sentido, é curioso notar que não há uma versão para o masculino desse processo de nominação. Não há notícias de nenhum "João ou José tal objeto”, o que explícita a existência de universos de gênero delimitados, em que objetos como automóveis, chuteiras de futebol, microfones e, também, a lata de spray, são considerados "do masculino".

Grafite é coisa de menina? Como uma das poucas mulheres nessa arte do hip-hop, a grafiteira que participa há cinco anos do projeto Salvador grafita, ${ }^{48}$ ligado à Prefeitura de Salvador, se dedica ao desenvolvimento de imagens femininas - bonecas personalizadas - em seus grafites e já expôs seus trabalhos em países como Itália, além de registros em revistas europeias especializadas na área. Mesmo respondendo por esse currículo que foi construído no decorrer desses anos, o interesse está em como foi sua experiência, em especial, ao adentrar no espaço do grafite como uma mulher grafiteira em Salvador.

MÔNICA: Claro, senti, senti muito preconceito.

PESQUISADORA: Dos próprios grafiteiros?

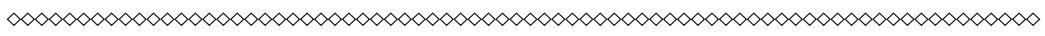

48 Projeto Salvador grafita, proposto e construído através do debate entre segmentos do movimento Hip-hop baiano e Prefeitura de Salvador. Esse projeto é administrado pela Secretaria Municipal de Educação e Cultura (Secult) e consiste na produção de grafiteiros e grafiteiras que trabalham com oficinas de grafite nas escolas públicas municipais, além de intervir com sua arte na estética urbana. (MORAES NETO, 2006) 
MÔNICA: Grafiteiro, companheiro, muito preconceito de dizer que meu trabalho não me qualificava no grafite, já fui colocada para pintar um muro pimenta ${ }^{49}$ você não consegue pintar; me dá um cantinho de muro, pequenininho, com uma parte de reboco sabe, você precisa ver aquele imenso jardim visto de fora, aquela coisa linda, em vez de incentivar, não, coloca aquela pessoa para pintar, mas se pudesse nem pintava no muro, assim como mulher, porque eles acham que o espaço é só deles entendeu, acham que só eles que tem que pintar, que só eles tem que fazer, e só eles que são capazes, e só eles que fazem as coisas mais bonitas, sabe? Acham que nós mulheres não somos capazes, então até hoje venho tentando mostrar que quem gosta é capaz de ter o seu espaço, sem precisar deles e fazer entendeu? Sofri muito preconceito, sim.

Mônica relembra uma experiência vivenciada junto ao seu marido - que também é grafiteiro e com quem tem duas crianças - que mostra o comportamento dos grafiteiros em relação às grafiteiras. Em seu relato, veremos como ela foi tratada pelos grafiteiros numa oportunidade de um trabalho de grafite coletivo:

Tem pouco tempo que meu marido foi para um grafite, foi convidado para um grafite, que ia ser um muro imenso. Chamaram ele, que chamou uns meninos, e ai eu perguntei pro meu marido: 'Por que não me chamou? Por que eu não pude participar?', 'Ah, eu não sei, porque disse que o muro já tava certo'. Isso não existe, é discriminação pô, é discriminação, sabe que eu também pinto, que eu tô dentro de casa, que eu também pinto, e sempre quando rola alguma coisa eu te chamo, para mim isso é discriminação entendeu? Eu acho assim, porque o grafite é mais para

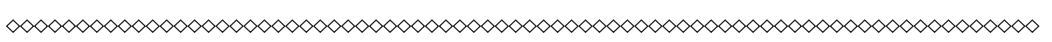
49 "Muro pimenta" é termo utilizado para um espaço em que é difícil para pintar. 
homem e pronto, entendeu? Mas se eu fizer o muro, e dá para todo mundo, pronto, o muro é pequeno, mesmo que dê para cada um colocar uma letrinha, um olho, mas dá para todo mundo fazer, tem um pouco de discriminação e essa parte eu não gosto, mas eu vou ter que lutar, eu estou sempre lutando para quebrar isso.

Mônica é questionada sobre como é ser mulher no grafite diante de suas experiências com diferentes vertentes do hip-hop. A grafiteira, que reafirma haver poucas mulheres no grafite e que fez uma enquete em sua página da rede social Orkut com a chamada "Quem disse que grafite não é coisa de mulher?”, respondeu-me que ser grafiteira:

É saber que lugar de mulher não é só na cozinha, não é só na panela, não lavando, não é cuidando de criança, que o lugar de mulher é também no meio do grafite, entendeu? Lugar de mulher também é no grafite, lugar de mulher também é pintando, e ser mulher é além de tudo é ser, é fazer, é chegar lá e meter a mão.

O caso de Mônica aponta para uma busca de transformação das convenções de gênero em torno da atuação das grafiteiras. Entretanto, Mônica afirma que tem encontrado muita resistência para a articulação das mulheres no grafite. Ela expõe a experiência de sua Crew, expressão que dá nome ao grupo de grafite (MATSUNAGA, 2008), que no seu caso é composto por outras duas grafiteiras de outros estados. Elas se comunicam pela internet e têm encontros eventuais, mas cada uma representa a crew em sua cidade e estado, e em oportunidades de viagens e eventos. Mônica relata ainda que em Salvador não consegue mobilizar grafiteiras para trabalhos coletivos, pois além de serem poucas mulheres envolvidas, não tem surgido interesse destas em grafites coletivos. Também cita os nomes de algumas grafiteiras que têm trabalhos 
reconhecidos na área, a exemplo das soteropolitanas Rebeca, Kátia e Lica, com as quais ela afirma que pintou muito pouco. ${ }^{50}$

Uma dessas oportunidades de pinturas coletivas entre mulheres, contando com a participação também de grafiteiros, aconteceu no III Encontro de grafiteiras (FREIRE, 2010), ocorrido em Salvador, em 2008. Esse evento, em especial, marca a segunda geração do movimento de mulheres hip hoppers soteropolitanas, por se diferenciar das características apresentas na primeira geração.

Esse encontro teve um caráter internacional, pois além de reunir representantes do grafite baiano e de vários estados brasileiros, também contou com a presença de grafiteiras de países da América do Sul. Um aspecto interessante dessa articulação é sua comunicação a partir dos espaços virtuais na internet, a qual possibilitou a realização de um encontro com essa dimensão, com o objetivo de uma troca de experiência entre as mulheres no campo do grafite por meio da criação de redes virtuais de ação.

Esse evento marcou a atuação de novos segmentos do hip-hop, tendo uma formatação e pautas bem distintas dos eventos organizados por mulheres hip hoppers da primeira geração do movimento baiano, atuante nos anos anteriores, que demarcavam uma articulação profunda entre demandas vinculadas à questão de gênero, raça, classe e a própria forma de identidade militante do hip-hop, além do intrínseco contato e participação de outros movimentos sociais, especialmente negros e feministas. O evento em questão assumiu uma articulação de maior caráter jovem e de mulheres, sem apresentar fortes tensões em relação à classe e posicionamentos de afirmação feministas.

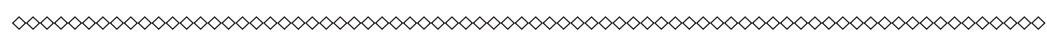

50 Algumas grafiteiras assumem o nome de Sista, uma referência adaptada pelo hip-hop para o termo sister, irmã em inglês, juntamente com a primeira letra de seu nome próprio, a exemplo de Sista K, a grafiteira Kátia. Vale ressaltar que Sister K, juntamente com outras grafiteiras soteropolitanas, foi uma das responsáveis por organizar o III Encontro de grafiteiras em 2008, e a Marcha das vadias (protesto feminista mundial contra a conivência à violência sexual contra as mulheres) ocorrida em Salvador, no dia 02 de julho de 2011. 
Talvez essa explicação de conjuntura possa dar subsídios para o entendimento do contexto de organização das grafiteiras, já que, segundo Mônica, há uma espécie de resistência para a organização das mulheres nessa arte. O relato da grafiteira é praticamente um desabafo, no qual aponta uma possível justificativa para esse cenário: a desunião entre as mulheres, tendo como principal interesse relacionamento íntimos - sexuais e afetivos com grafiteiros:

Muito o que eu vejo hoje são mulheres para quem grafiteiro é troféu, elas não procuram se unir, eu acho também muita falta de união, de chegar. Tem grafiteira que tá no meu Orkut, mas sequer ela fala 'Oi, tudo bem, tá pintando, tá pintando muito por aí?' Sequer dá resposta. Tudo bem, não tem necessidade disso, eu sou grafiteira, ela também é, eu acho que é por educação que eu tenho que falar dar um oi para pessoa. Às vezes eu chamo para pintar, tem gente que não vai, eu não sei que é porque tem gente que tem intriga com meu marido, intriga com minha crew, ou um pessoal meu, eu fico besta, muita má vontade para pintar, porque os meninos querem, conseguem se reunir para pintar? As meninas não podem fazer isso? Eu tenho cinco anos de grafite, e se eu pintei com as meninas de Salvador aqui foi pouco, pouquíssimo, e faço a maior questão da gente pintar, porque a gente tem que se unir, a gente tem que acabar com isso, o crew, crew, beleza, grafite é grafite, vamos se juntar, vamos pintar.

A justificativa utilizada por Mônica para a resistência à organização ou mesmo as pontuais ações entre grafiteiras, o "grafiteiro troféu", reproduz as normas tácitas de gênero de que há a necessidade de autorização e legitimação do masculino para a que o feminino se aproprie de atributos de seu universo. Nesse processo ambivalente de reforço das convenções e transgressões das 
regras, ao se apropriarem de um atributo e elementos do universo masculino, as grafiteiras desafiam essas mesmas convenções.

Interessa aportar como essa relação de ambivalência e de desafio aparece na produção artística da grafiteira. O grafite de Mônica, exposto na Avenida Carlos Gomes, no centro da cidade, traduz esta sua inquietação em relação ao mundo do grafite, sendo seu trabalho alvo de muitas críticas de diversos segmentos do movimento, a partir da representação das mulheres nos grafites em condições minimalistas e subjugadas, como mostram as fotos.

Figura 2 - Grafite de Mônica Reis na Avenida Carlos Gomes - Centro da cidade

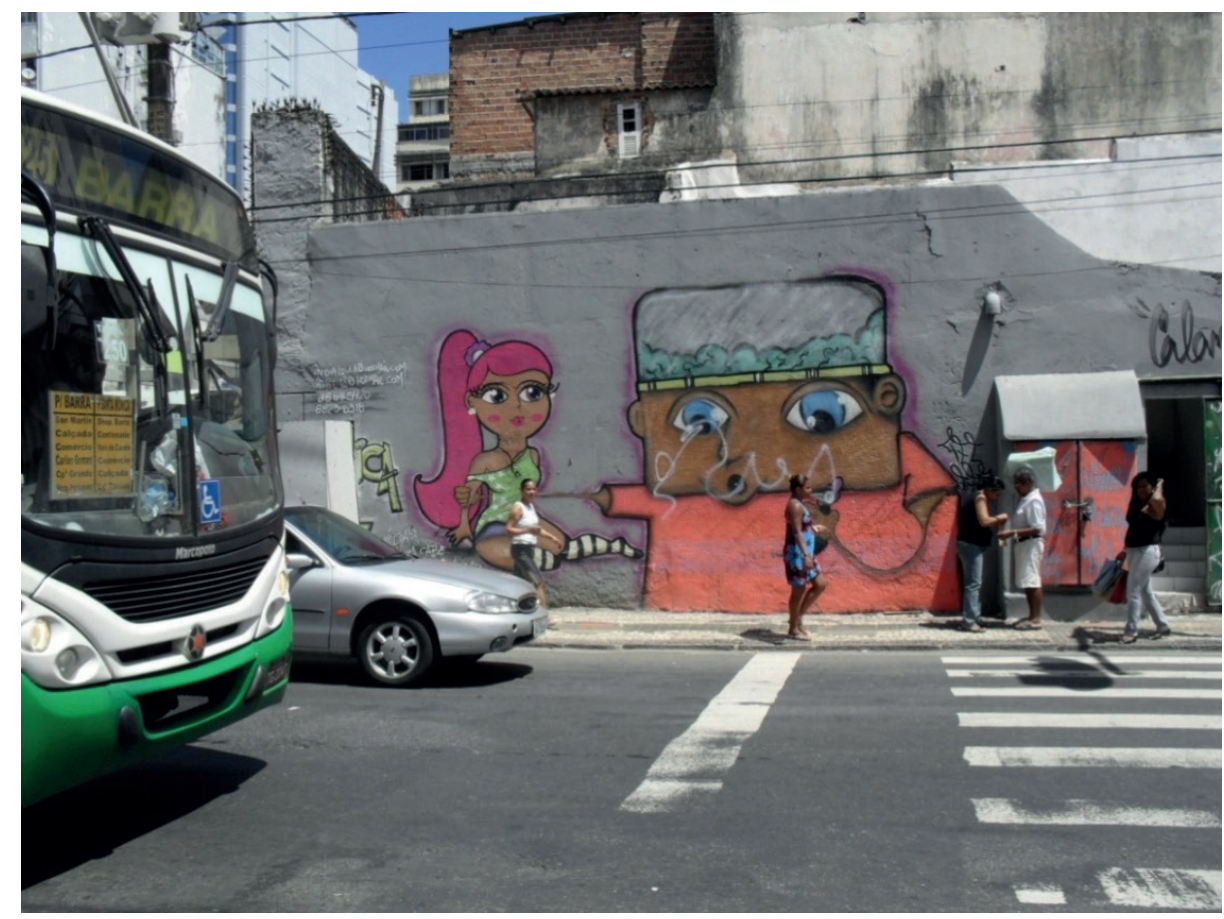

Fonte: produzido pela autora. 
Figuras 3 e 4 - Detalhes de grafite de Mônica Reis na Avenida Carlos Gomes - Centro da cidade

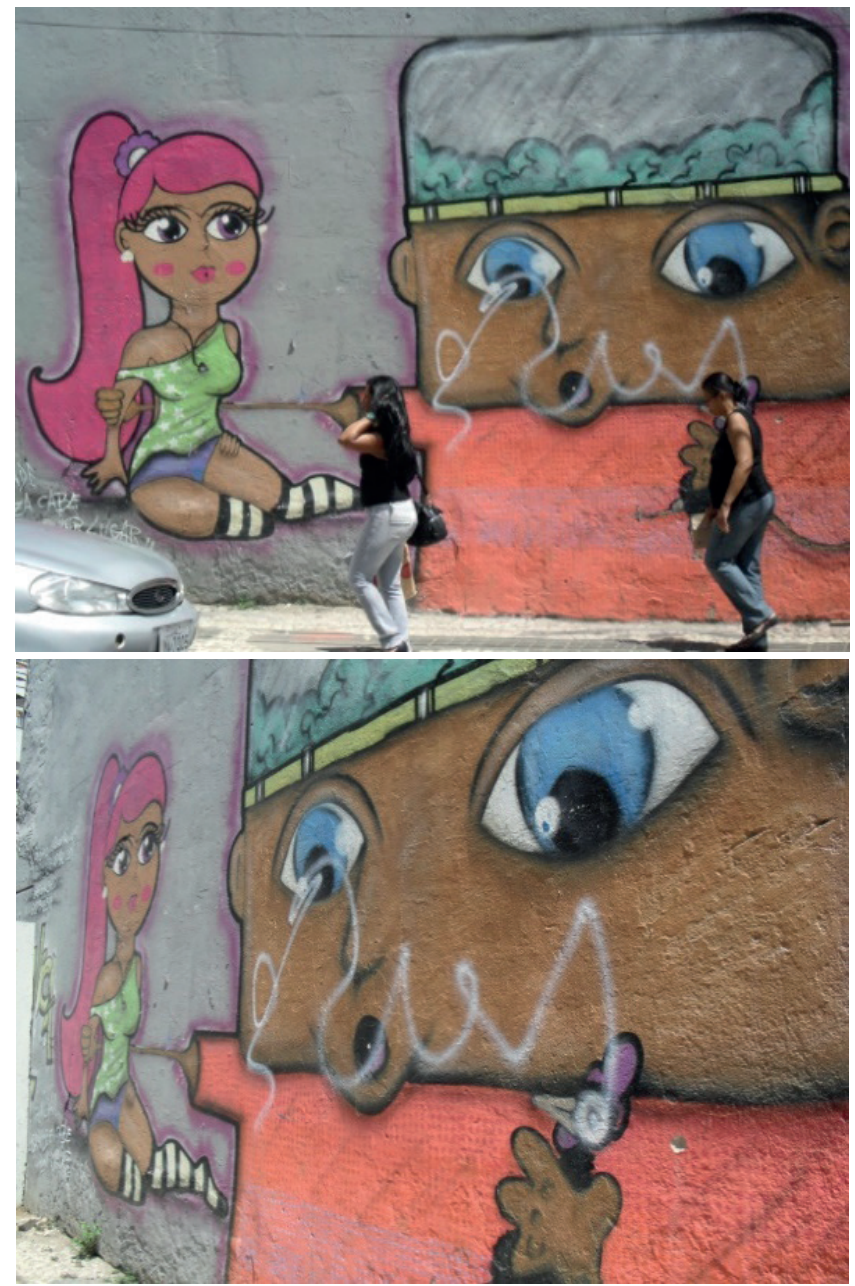

Fonte: produzido pela autora (2010).

O grafite de Mônica exibe uma pequena menina grafitada sentada no chão, aprisionada nas mãos de um grande menino, maior do que ela em força e tamanho. Na outra mão do menino, feito por um grafiteiro - há duas assinaturas no muro, o que parece ter sido um trabalho em dupla de um grafiteiro e uma grafiteira -, há um 
pássaro também aprisionado, transmitindo e reforçando a ideia de força e fragilidade das próprias dimensões dos desenhos.

O próximo tópico apresenta como essas convenções de gênero do feminino e do masculino se expressam no elemento break.

\section{Aula de break com uma mulher? Relatos da única b-girl da comunidade}

Entre as primeiras linguagens do hip-hop surgiu o break, a dança de rua também conhecida por street dance, que se expressa em diferentes estilos, entre eles, o poping, o breaking e outros. O break é responsável pela linguagem corporal do movimento, que traz consigo passos e gestos tomados de uma conotação de irreverência e de protesto, como nos outros elementos do hip-hop.

Embora o break seja a dança do hip-hop, não é exatamente dançada por rappers, grafiteiras e grafiteiros, ou mesmo pelo DJs ou djeias. Quem dança break são b-girls e b-boys, sendo a letra "b" abreviação da palavra break. Break significa "quebra" em inglês, que segundo autoras(es) e pessoas do movimento simboliza os corpos quebrados e mutilados dos soldados como protesto à Guerra do Vietnã ${ }^{11}$ (SOUZA, 1998), e também a situação de marginalidade e descaso, em especial em relação à saúde e moradia, vivenciada pela população negra e imigrantes nos Estados Unidos.

Para executar os movimentos dessa dança, $b$-girls e $b$-boys precisam de bastante força física, habilidade e coragem para ousar a realização de seus passos, pois esses reúnem diferentes danças e artes marciais, e são compostos por saltos em diversos níveis, coreografias e improvisação, a exemplo de floreios da capoeira que podem ser reconhecidos na adaptação ao break realizado no

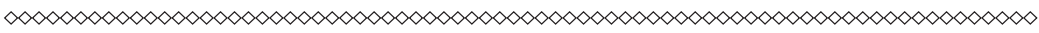

51 Em relatos de militantes e em suas versões sobre a Guerra do Vietnã, jovens negros foram colocados como linha de frente nos combates contra os vietnamitas. 
Brasil $^{52}$ e na Bahia. Isso pode ser explicado devido ao break compor uma série de passos e movimentações, mas que permite a inclusão de cultura corporal local como a capoeira, dança afro e até samba.

É possível encontrar apresentações do break em espaços públicos, como em praças da cidade e também na frente do palco em shows de rap e discotecagem em bailes black. São comumente reconhecidas entre jovens na cidade por roda de break, e reúnem transeuntes que aplaudem como torcidas as sequências de apresentações individuais e até coletivas de contagiante vibração ao som das batidas de um rap bem dançante e muitas mixagens.

Em sua maioria de b-boys, quanto maior o grau de dificuldade e ousadia do movimento, maior exigência de esforço físico, a interpretação do dançarino ou dançarina, e sua interação com o público, maior é a reação da plateia. Essa dança envolve um trabalho corporal praticamente ou próximo a um formato atlético. É o que acontece na roda de break que ocorria regularmente no Pelourinho, ${ }^{53}$ às terças-feiras.

Para conhecer experiências que contenham características simbólicas investigadas nas convenções de gênero no break foram acompanhadas atividades específicas com o break e entrevistadas algumas $b$-girls que desenvolvem a arte da dança de rua no movimento Hip-hop.

Entretanto, o número de $b$-girls é bastante reduzido se comparado com o número de $b$-boys. Esse cenário mais uma vez me remeteu ao artigo "Onde estão as b-girls?", em que Noronha (2007) apresenta a mudança de curso de sua pesquisa diante da falta de representações femininas nesse elemento do hip-hop. Não foi

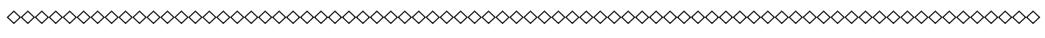

52 Esse aspecto de envolvimento da capoeira com o break também foi encontrado na pesquisa sobre hip-hop em Florianópolis (SOUZA, 1998), o que aponta a inclusão ou mesmo o diálogo dos passos clássicos do break com um aspecto da cultura brasileira, no caso a capoeira, que une dança e luta em sua composição.

53 Centro Histórico e Cultural Pelourinho localizado na parte alta da cidade de Salvador, bastante frequentado pela população soteropolitana e por turistas. 
o caso de Salvador, pois as b-girls, mesmo em um número menor, demonstram dominar a prática dos estilos de break dancing ao realizarem exercícios de alto grau de dificuldade, como malabarismos e contorcionismos, se apresentando não apenas na roda de break no Pelourinho - onde treinam junto com os b-boys -, mas também inseridas em grupos de dança de rua; além disso, competem em campeonatos e ministram atividades educacionais como aulas e cursos de break para juventude, a exemplo do citado curso de formação de $b$-girls.

Figura 5 - Aula do Curso de formação de b-girls (CEAO, 2008)

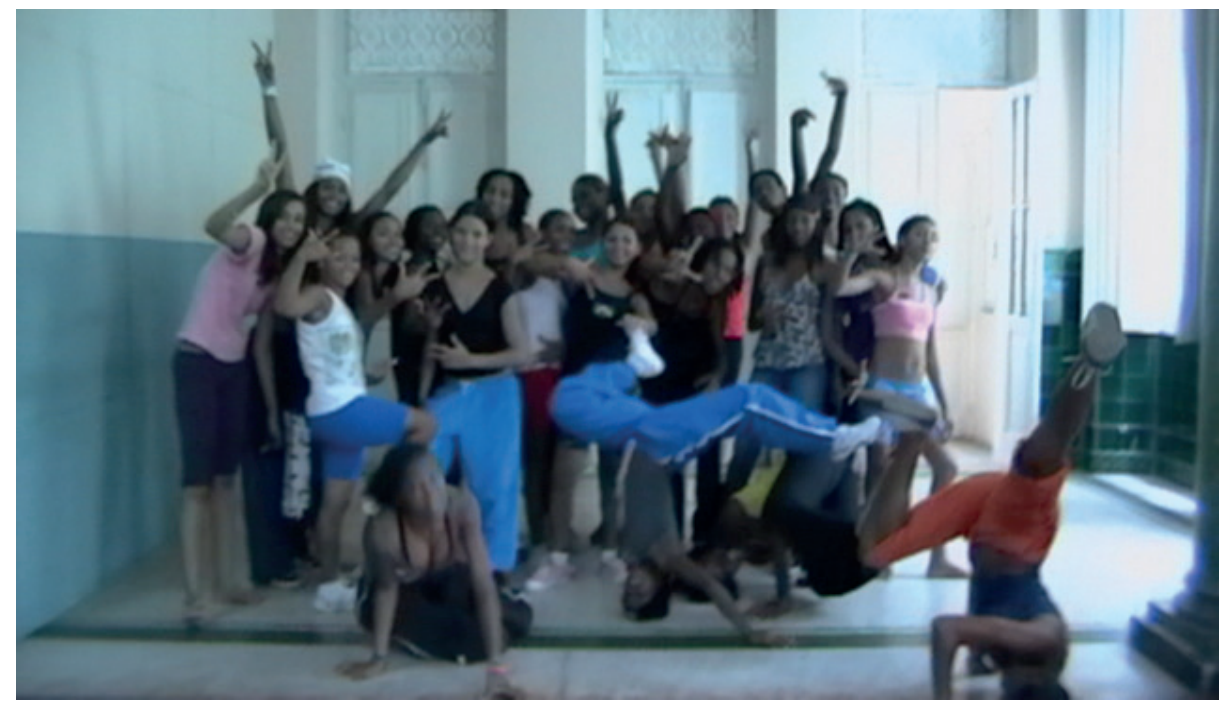

Fonte: produzido pela autora.

A experiência da $b$-girl Priscila Nayala - como professora de dança de rua - ao dar aulas práticas de break em sua comunidade é exemplar para compreendermos as convenções de gênero e a produção de desigualdades no hip-hop, a partir do elemento break. O principal empecilho em torno da ação da $b$-girl estava na noção de que hip-hop não seria coisa de menina, e que as pessoas com as 
quais ela se relacionam, familiares e amigos, não entenderiam sua relação de envolvimento com esse movimento.

PRISCILA: Muitas, principalmente do preconceito, que acham que a dança de break, acham que o hip-hop é pra menino e não pra menina, ainda existe isso, ainda existe este preconceito e eu sofro bastante com isso, inclusive dentro de casa. A minha mãe que deveria me apoiar é a primeira, minha mãe é a primeira a falar. [...] Sabe, ela não conversa mais sobre isso, não, aliás, quando, às vezes ela reclama, ela fala assim: 'ah, Priscila, ô como você está ficando toda musculosa, você está ridícula, você está quadrada', ela me bota pra baixo mesmo, entendeu, assim, mas, não porque [...] é coisa de mãe, quer proteger, é, assim mesmo [...]

PESQUISADORA: Você tinha quantos anos?

PRISCILA: Tava com... tava com dezesseis, dezesseis anos. Aí.. eu fui, né, dá aula...quer dizer eu ia fazer dezesseis, eu tava com quinze ia fazer dezesseis, ai fui comecei a dar aula, chegou em casa, eu peguei menti pra minha mãe, porque eu sabia que ela não aceitava, menti pra ela, disse que eu estava fazendo um curso de informática, eu nunca fiz esse curso de informática, eu estava dando aula pra esses meninos.

Diante de uma rotina diária de exercícios físicos, o resultado físico mais imediato é o fortalecimento dos músculos, e, consequentemente, a quebra de um modelo de feminilidade envolvendo as convenções de gênero definidas para o ser mulher, frágil (no sentido de delicada) e fraca (no sentido de pouca força), modelo que envolve aspectos como submissão e invisibilidade.

Esse modelo de feminilidade é transformado visivelmente através da musculatura e contornos corporais das b-girls. Esse é 
um dos aspectos visíveis em seus corpos devido à sua rotina de exercícios físicos exibidos nas coreografias do breaking dancing.

O preconceito de alguns homens em relação às mulheres que desejam se inserir no movimento também encontrou força dentro de casa, por entes da família, quando esta ideia de que o espaço e ações do hip-hop, a exemplo da dança, não seria um espaço para as mulheres. Priscila compartilha sua experiência em relação à prática do break.

Eu sendo mulher e falando da minha relação com os rapazes do hip-hop, ainda mais na localidade onde eu moro, às vezes, é um pouco assim, de transar, porque os meninos do hip-hop, você sabe como é, não gosta de ver menina nenhuma no break. Ainda mais, quando a gente dança melhor que eles, eles já não gostam, acham que a gente está tirando onda, acham que a gente fica querendo saber demais e eles são melhores, os gostosões da parada, porque eles dançam, as meninas gritam, então, eles se sentem mesmo, né. Aí, quando a gente vai dançar, eles acham ruim, né? Então, de vez em quando eu encontrava um, era difícil, eu encontrar um que falasse, assim 'não, você dança legal, dance aqui comigo, venha, entre em meu grupo, porque a maioria é sai daqui', menina sai, nem venha, entendeu? Geralmente, é assim.

Na fala da $b$-girl Priscila, apareceu, mais uma vez, a ideia da invasão das mulheres em um espaço que era exclusivo dos homens, reconhecendo que sua presença transgredia as convenções de gênero no hip-hop, desafiando a ideia de que o break não é um espaço para as meninas. 
Entre as $b$-girls de maior destaque no meio do movimento Hip-hop soteropolitano nos últimos anos estão ${ }^{54}$ Negramone, Josy e, também, Tina, responsável pela roda de break que ocorre no Pelourinho e que desenvolve juntamente com seu namorado, b-boy Ananias, com quem produz a grife de roupas "Hip-hop".

Outro aspecto muito destacado nas falas das hip hoppers em diferentes elementos, inclusive no break, é com relação às referências de outras mulheres no hip-hop e ao reconhecimento de seu próprio trabalho como referência para outras mulheres.

PRISCILA: Humhum [afirmativo]. É realmente lá, onde eu moro, como não existe nenhuma B-girl e eu sou, assim a única lá em São Cristóvão, então eu acho que realmente eu sou importante pra que não deixe essa cultura morrer e pra que, também outras meninas possam se espelhar em mim, e tentarem ser B-girls, também. Porque eu acho que... como eu sou a única e tô lutando, tô sofrendo muito, né? Pelo fato de ser a única, então se as meninas me verem lá, lutando, elas podem se espelhar em mim, e nunca desistir, nunca desistir de correr atrás, só pelo fato de que tem alguém criticando. Eu acho que na vida a gente tem vários degrais, vários testes e a gente tem que subir estes degraus, tem que pular essas barreiras, subir essas paredes / [...] Quando, tipo isso aí, agora veio Fabiana, de Brasília, a B-girl e deu uma expectativa enorme pra gente, entendeu, eu tava meio pra baixo, já fiquei já mais pra cima. Pôxa, velho, ela dança pra caramba! Quero ficar, assim exatamente como ela, quero dançar completamente como ela ou quem sabe, melhor que ela, entendeu? muito bem. Lá em São Cristóvão não

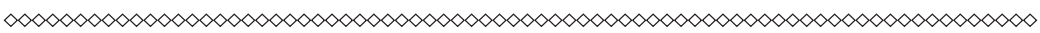

54 As duas b-girls participaram do Curso de Formação de B-girls, no qual Negramone foi a principal idealizadora e responsável do planejamento. Josy atuou de forma relevante nos primeiros momentos do curso, porém, devido à sua primeira gravidez, não pôde dar continuidade à sua participação. Tina também foi convidada para dar aulas de break, mas devido à falta de apoio do namorado, também b-boy, não teve sua efetivação no curso. 
tenho muitas influências, não. Porque a galera lá não tem muito contato, assim, quer dizer na verdade, contato até tem, só que eles não dão valor. Nem todo mundo dá valor. A maioria lá, na rua onde eu moro, assim, a galera dá valor a pagode, arrocha, essas coisas, assim e não a dança do break. Então, eu acho que isso, ai, que me bota pra baixo, entendeu? Quando tô dançando, (fazendo alguma coisa) e a galera não leva a sério, dá risada, vai falar que isso não é pra mim, que eu deveria me comportar, coisa e tal, além do mais, até minha mãe, mesmo, ela reclama muito.

A turma do curso de formação de $b$-girls teve a oportunidade de receber a b-girl "Fabi Girl”, de Brasília. Conhecida por participar de campeonatos internacionais de dança de rua, e por participar de um grupo de break composto apenas por mulheres do Distrito Federal, Fabiana trocou experiências com as jovens iniciantes $b$-girls, mostrando algumas possibilidades de atuação e trabalhos com essa arte da dança como uma alternativa profissional.

Para tanto, como um suporte para se pensar as formas de uso das artes do hip-hop, uma das questões bastante em voga apresentadas pelo movimento foi a preocupação com o estudo sobre o próprio hip-hop. É comum esta relação em torno de textos, indicações de filmes, leituras sobre o tema.

É um contato assim, que, pôxa, fortalece bastante, porque outras meninas vão ver isso, e elas vão perceber que elas não conseguem. Então vai ser tudo, pra outras meninas vai ser tudo. Que às vezes elas se sentem só, eu lá em São Cristóvão, eu me sentia muito só, às vezes. Eu ficava perguntando - Pôxa, Robson... - Robson sumia, velho. David sumia, - Pô gente, não se afaste de mim, não. Porque sem vocês aqui eu me sinto só - Ficava brincando com 
ele - pô, Robinho, passe mais lá em casa, nego. Converse comigo sobre a história do hip-hop. Até um livro de hip- hop que ele deixou para mim ler, coisas. Eu falava - toda informação que tiver traga para mim, pô. Não suma, não, sente aqui, converse comigo, eu ficava caçando a galera do hip-hop, pra mim me sentir bem. Porque quando eu tava sozinha, era bastante discriminada, e eu, sempre, e eu como tenho depressão, então é fácil d'eu entrar em uma crise, eu chorar, entendeu? Eu me sinto só, pô. Então eu ficava falando direto com Robinho - Pô, Robinho não suma, não, fica aí, conversa comigo, e coisa e tal. Passava direto na casa de David, a gente conversava sobre hip-hop. A gente falava de Munegrale, falava da Rede Aiyê, e eu sempre querendo conhecer a banda-Rapaz, me fale dessa banda, rapaz, como é que é isso e coisa e tal - entendeu? Ai, pôxa, na correria, aí, até que finalmente, eu conheci a galera do Munegrale, conheci esse grupo aí, a galera da Rede Aiyê, adorei, Eu acho muito importante mesmo pra quê as meninas possam ver e tomar isso como base e ficar fortalecida. (Priscila)

O caso de Priscila é bem ilustrativo para se pensar as convenções de gênero em torno da feminilidade e da masculinidade na sociedade, e também no âmbito do movimento Hip-hop soteropolitano, a partir de suas aulas de break. Ela mora na comunidade de São Cristovão, um bairro de periferia localizado nos limites entre Salvador e Lauro de Freitas, de numerosa população, afastado do centro da cidade e conhecido por altos níveis de problemas sociais. As aulas acontecem no mesmo bairro, Priscila conta como foi sua experiência com o projeto Escola Aberta, ${ }^{55}$ desenvolvido na

$\infty<\infty<\infty<\infty<\infty<\infty<\infty<\infty<\infty<\infty<\infty<\infty<\infty<\infty<\infty<\infty<\infty<\infty<\infty<\infty<\infty<\infty<\infty<\infty<\infty<\infty<\infty<\infty<\infty<\infty<\infty<\infty<\infty<$

55 Desenvolvido nas escolas públicas - em diversos estados brasileiros - a partir de articulações entre o Ministério da Educação, a Secretaria da Educação do Estado da Bahia e a Unesco, com caráter de atividades extras aos horários regulares da Escola, aberta as comunidades. Disponível em: <http://www.educacao.escolas.ba.gov.br/node/361>. 
escola pública do bairro como uma atividade extra, aberta para a comunidade, sendo ela a única $b$-girl da comunidade e ainda professora de break nessa oportunidade.

PESQUISADORA: Quem é esse público?

PRISCILA: Tinha criança de dez anos, tinha adolescente de dezessete, dezesseis até vinte anos, tinha até senhor de idade, lá, de cinquenta anos, tinha [...]

PESQUISADORA: E qual o sexo?

PRISCILA: Homens e mulheres. De começo tinha bastante homem, depois começaram a vir as meninas e aí ficou uma concentração legal de meninos e meninas. Com o passar do tempo os meninos foram sumindo ficou mais meninas que meninos, ai agora o projeto encerrou, aí voltou de novo, entendeu? Mudou de dezesseis pra dezessete, agora entrou mais meninos que meninas. Então esse ano eu resolvi fazer divulgação nas escolas, até nas escolas de São Cristóvão comecei a divulgar: 'Gente tá tendo um curso de graça de formação de B-boy e B-girl na Escola Parque de São Cristóvão', e aí, chamei, fui de escola em escola pelas manhãs, pelas tardes, fui de sala em sala comunicando isso e ainda fazendo demonstração do que era o break, falando o que era o hip-hop, quantos elementos que compõe o hip-hop, tudo isso, pra galera se interessar, peguei uma lista passei, [...] interessado assine aqui, a galera assinou... e, aí hoje que eu vou me encontrar com essa galera toda, ai, das escolas [...] mais tarde, daqui a pouco eu tô lá na Escola São Cristóvão pra dar aula pra esses meninos. Então, o projeto lá eu tô numa correria sozinha. 
Priscila expõe a reação de seus estudantes com o primeiro contato em busca de suas aulas, e faz observações sobre o estilo hip-hop de ser:

É uma coisa que eu acho interessante. Veja bem, é, os meninos de começo, não aceitava muito isso, não, entendeu? Quando ouviu falar 'tá tendo aula de break, aí, e os meninos 'nossa, vamos lá, que massa', quando chegam lá, 'ah, é uma mulher?'. Pelo amor de Deus, todo mundo queria sair, aí, falaram assim: 'não, péra, aí, péra aí, bóra ver, né?', 'bóra ver como é isso aí' e aí foram. Passado um tempo eles foram gostando, vendo que não tinha nada a ver, negócio [...] de ser homem, de ser mulher, entendeu? Foram, gostaram e continuaram e de começo só tinha menino, chegou a mãe de uma aluna, lá, olhou assim, ai falou: 'Que nada, vou botar minha filha aí, não. No meio desses marginais, tanto vagabundo na sala, cheio de brinco, de correntes, de roupa folgada. Não vou, não vou deixar minha filha, aí, não.' Falou, bem assim. Eu fiquei assustada com a situação. Olhei, assim, é... também não falei nada, né? Fiquei na minha. Depois eu cheguei comentei com os meninos e coisa e tal. Aí, a secretária conversando com a mãe da menina, né? Passado um tempo, aí, sim, conseguiu deixar com que a mãe liberasse a menina pras aulas, porque ela não queria deixar a filha dela lá.

Priscila já tinha completado dois anos de aulas no Projeto, e já tinha estudantes mulheres em suas aulas de dança, o que aponta a repercussão de seu trabalho e reconhecimento da abertura desse espaço de lazer e cultura para as jovens de seu bairro. Quando questionada sobre a diferença entre o comportamento das mulheres e dos homens nas aulas de break, ela responde: 
Mulheres e mulheres... Vejamos, eu acho que no hip-hop as meninas, com as outras é uma coisa, é uma coisa melhor, é bem mais legal, assim, porque as meninas elas se unem. Elas sempre se unem, conversam, trocam algumas ideias, trocam informações, assim, trocam atividades, muitas, muitas, muitas relações, eu acho que uma ajuda a outra, é um comportamento super legal, lá na escola mesmo, eu vejo direto isso. Quando eu falo assim, quando passo um trabalho - gente, faz uma pesquisa e coisa e tal - as meninas são as que mais pesquisam, elas se juntam, formam as equipes delas sozinhas, já os meninos ficam todos desnorteados, entendeu? Eu, eu que tenho de ir, lá, formar equipe pra eles, eu que tenho que intervir [...] Ai, geralmente quando eu passo alguma coisa, assim, as meninas são as que mais correm atrás, e elas se unem bastante, já os meninos brigam até um com o outro. 'Não vou fazer nada com esse cara, não. Que nada, rapaz, com um marmanjo desses, que é que isso, que aquilo.', já as meninas, não: 'venha, fia, umbora fazer comigo', entendeu? Elas se unem mais do que os meninos.

É interessante constatar essa concepção de união feminina da $b$-girl com a desunião apontada pela grafiteira. Uma hipótese para essa disparidade de percepções deve-se ao fato da maior presença, e há mais tempo, de mulheres na prática dos referidos elementos. Talvez o fato de as $b$-girls enfrentarem há mais tempo as convenções de gênero no break possibilite a elas já desfrutarem de algumas conquistas, mesmo ainda sofrendo com algumas sanções oriundas das transgressões que impõem ao hip-hop.

Interessa, ainda, destacar que impõe a relevância da sua prática no desafio mais densamente relacionado a modelos de feminilidade vigentes. Ao transformarem seus corpos, dotando-os de atributos e sentidos comumente associados ao masculino, à força 
e agressividade, estão introduzindo novas possibilidades às convenções de gênero já normatizadas e naturalizadas. Tais desafios e novidades podem ressignificar, também, padrões de conjugalidade e convenções de sexualidade. A análise a seguir nos traz mais dados para se refletir nesse sentido.

\section{Militante objeto sexual - "A carne na frente do leão"}

No elemento militância do movimento Hip-hop não há uma necessidade de envolvimento com um elemento específico, ou mesmo há a possibilidade da criação de um novo elemento. Como representantes do elemento militância do hip-hop soteropolitano, apresento Vivian e Eliciana.

Ambas têm uma longa trajetória no movimento, porém não assumiam a prática de nenhum dos elementos clássicos do hip-hop. No caso de Vivian, a hip hopper produziu inúmeras atividades do movimento na cidade e chegou a representar o hip-hop soteropolitano em encontros em outros estados, mas não chegou a se especializar na arte que mais aprecia dentre os elementos clássicos do hip-hop.

Vivian é admiradora da arte que mixa diversas batidas e que agita os bailes black. A respeito do trabalho das djeias, está vinculado à criação e apresentação das batidas musicais dançantes ao lidar primeiramente com equipamentos tecnológicos - não exatamente instrumentos musicais, mas equipamento de som e outros materiais -, embora haja DJs que trabalham apenas com computador e arquivos e programas musicais.

Entretanto, é rara a atuação de djeias em Salvador, visto que há dificuldades em adquirir o kit DJ com pickup, caixas de som, acervos de vinil e outros. Essa situação pode ser justificada pelo seu excessivo valor no mercado, mesmo quando se refere a 
um material já em uso, afastando a possibilidade de que jovens da periferia, homens e mulheres, tenham chances de comprar esse $k i^{56}$ e se tornem djeias e DJs. Esses critérios inviabilizam a expansão dessa arte, resultando na praticamente inexistência de djeias soteropolitanas. ${ }^{57}$

A partir desse contexto, o hip-hop apresenta novas configurações de militância e cria novos elementos na sua interação entre política e cultura. É o caso de Eliciana, que nos apresenta um novo elemento embutido no hip-hop soteropolitano. A hip hopper se apresenta como Vjeia, sendo o masculino o termo $\mathrm{VJ},{ }^{58}$ que pode ter referência nas djeias e DJs.

Enquanto a djeia realiza seu trabalho ligado a discos, geralmente com vinil e pickup, a Vjeia atua com filmagens e criação de imagens do movimento com câmeras de vídeo e máquinas fotográficas. É o que explica Noronha (2007, p. 189) diante da

possibilidade de entender os circuitos e a lógica dos rappers (e hip hoppers) na cidade tornaram evidente a ideia de que o hip-hop não era algo homogêneo, mas constituído por jovens que apresentavam diferentes discursos linguagens artísticas e formas de organização.

Vale ressaltar que há a legitimação do elemento militância para além da necessidade de criação de um novo elemento, sendo o caso de Vivian. Ela atua nas articulações do movimento na cidade e fora dela, bem como produz atividades, projetos e documentos

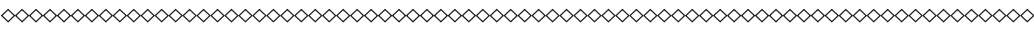

56 Além desse kit djeia, com pickup (toca-discos vitrola especial para samples), vinis (quanto mais antigos e raros, mais caros) e cases (caixas de proteção apropriadas) para transporte, há o próprio custo do transporte, em caso de pagar frete, táxi ou mesmo pagar a gasolina no caso de uma carona, o que afasta a tentativa de muitas - e muitos - hip hoppers no investimento do desenvolvimento dessa arte.

57 É possível encontrar djeias soteropolitanas nos estilos techno e/ou eletrônico, não sendo parte da cultura hip- hop.

58 Vj seria um Video Maker Musical, uma mestre de cerimônia que apresenta videoclipes contando sobre músicas e artistas. Pode ser também uma pessoa que produz esse próprio material audiovisual. No entanto, esse não é um dos quatro elementos do hip-hop. 
em nome do movimento, além de sua representação ser reconhecida como hip hopper. É o que explica Eliciana:

ELICIANA: Só a militância.

PESQUISADORA: Só?

ELICIANA: Hum, hum só. [risos]

PESQUISADORA: Tu pode assim pensar um pouco esse elemento, falar um pouco sobre esse elemento?

ELICIANA: Eu acho que..., por a... a velha guarda como diz, que o hip-hop tem quatro elementos, mas assim no meu ver que... esses quatro elementos não andam sem a militância, porque, assim a maioria das pessoas que eu conheço, como Simone, Paula, todo mundo faz parte de um elemento e não esquece a militância. E se não militar pra onde vai o hip-hop? Vai ficar só... na dança na música e mais nada. E tem que ter a parte do correr atrás, é aí de onde vem a militância. Sempre tem pessoas dentro do hip-hop que só faz a militância, que não se... que não se identifica com os quatro elementos, mas gosta da ideologia e da militância.

A militância é responsável pela constituição do hip-hop como movimento social, pois ultrapassa os limites de uma cultura hip-hop que se apóia na produção de suas artes. É o elemento que permeia todos os outros elementos artísticos do movimento Hip-hop. Porém, é a partir da experiência de militância de Eliciana, apelidada de Lis, que observaremos um caso ocorrido durante o desenvolvimento de um dos seus trabalhos de vídeo, voltado para seu trabalho de militância como representante do movimento Hip-hop. Esse caso foi chamado de "A carne da frente 
do leão", por questionar as convenções de gênero e de sexualidade e a legitimidade das mulheres como militantes no hip-hop.

Eliciana gostava de rap e funk quando criança, e durante o trabalho de campo flagrei ela brincando com rimas e "mandando" 59 muito bem no freestyle (improvisação). Como dançarina de rua aos dez anos de idade, ela chegou a participar de um grupo de funk, chamado Funk cobra girls, no qual dançou em um dos primeiros bailes black da cidade. ${ }^{60}$

No decorrer de seu envolvimento com o elemento social ou político do hip-hop, ela participou de produções de inúmeros projetos e eventos do Movimento. Entretanto, seu trabalho principal foi com a produção de documentários, entre eles, III Encontro de Gênero e Hip-Hop, A saga da casa do Hip-Hop e Hip-Hop em sete vidas, dentre outros. Eliciana nos conta o caso:

Assim, eu, por exemplo, que estou produzindo esse documentário, assim, é muito difícil a gente não ser vista como símbolo sexual, a gente mulher, não tem jeito, é foda, lugar de trabalho, onde for. No meio do hip-hop, por exemplo, nesse processo de produzir o documentário, eu estou conversando com os caras, não dá pra eu ter uma conversa só de militante pra militante. Como é que tá o movimento aí, num sei que, a gente tá fazendo isso, fazendo aquilo. O cara vê você como, no meio do hip-hop como 'uma mulher pros caras' sabe? Vê assim. E recentemente passei por uma situação com uma figura famosa, que eu tava entrando em contato pra entrevistar; ele que não é daqui, eu já conhecia ele, ele já me conhecia de outros eventos de que eu participei e ele perguntou se eu ia fazer um Tour com ele em Salvador e eu perguntei pra

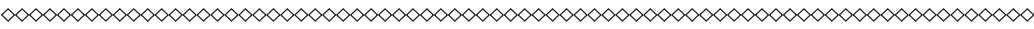

59 "Mandando", gíria no movimento para um resultado positivo, compondo letras e expondo-as ao cantar livremente.

60 Esse episódio terá atenção no próximo capítulo. 
ele se essa era a condição pra fazer a entrevista de que eu precisava. Porque era isso que ele tinha entendido, o que ele queria, que a gente fizesse uma troca. Eu fazia a entrevista que eu queria pra o documentário e me vendia pra ele, embora a gente tivesse falado tanto de movimento social, de militância e tal, enfim [...] embora fosse militante e eu, depois que eu fiz essa pergunta ele: 'não, não quero que você entenda assim, me desculpe, me perdoe, eu reconheço como você é guerreira, num sei que, num sei que, num sei que, você vai fazer a entrevista!' E durante o dia que eu passei com ele, que eu acompanhei o processo todo, ele não parou de me cantar! Então, aconteceu a entrevista [...] mas eu era mulher e isso faz com que tudo que exista de militância, de pessoal profissional, de qualquer coisa, de mulher forte, caia pra ser simplesmente uma pessoa que ele vai cantar você, fazer sexo e pronto. Enfim, é a gente tentar todo dia não, é você ser a carne na frente do leão e tentar dialogar com ela ao mesmo tempo e o leão quer te comer, porque não enxerga você como nada além do que uma carne que ele quer comer. É foda.

Este significante de objetificação e disponibilização sexual do corpo feminino, como "uma mulher pros caras", é questionado pelas mulheres hip hoppers, que transgridem essa convenção ao adentrarem no espaço do movimento com objetivos mais direcionados à sua própria militância e formação profissional. Eliciana demonstrou em sua experiência que "não dá pra eu ter uma conversa só de militante pra militante" Isso se confirma nas formas de objetificação do feminino, em especial das mulheres negras, significadas pelas convenções de gênero e sexualidade.

Ao considerar um homem "famoso" e ainda mais "turista" na cidade de Salvador, a representação da militante tomou forma de "carne na frente do leão". Mesmo o hip hopper em questão, 
que na mídia fomenta o nome do movimento Hip-hop ao que, reivindicando transformação social e combate às discriminações, reforça as convenções de gênero que dão significado ao modelo de masculinidade potente, caçador, implacável e galanteador, mesmo diante de um contato de trabalho, portanto, espaço de militância do movimento.

A militância da hip hopper, minimizada a elemento de troca por prazer em detrimento de informações sobre e para o movimento, perdeu importância diante do hip hopper que apenas "não enxerga você como nada além do que uma carne que ele quer comer". Ao questionar o comportamento do entrevistado, a Vjeia contestou o modelo de masculinidade e de feminilidade posto por uma lógica de gênero ao reformular a postura dada à sua militância.

Diante dessas e de outras questões que envolvem a militância das mulheres jovens no Hip-hop, as experiências relatadas mostraram as motivações e oportunidades de atuação das mulheres nas artes e na militância desse movimento social, ao passo que dialogam com as convenções de gênero no hip-hop, que em alguns momentos são reforçadas e, em outras ocasiões, reformuladas diante de situações e casos vivenciados pelas hip hoppers.

Como se pode perceber na análise das situações apresentadas, o primeiro passo em direção à contestação das convenções de gênero é a própria presença das mulheres, o que pode ser entendida na chave analítica de Anne Phillips (2001), a qual trabalha com a distinção entre a política das ideias e a política da presença.

Segundo Phillips, há uma crescente exigência democrática por "presença política" pelos grupos marginalizados ou excluídos historicamente de participação, a exemplo de mulheres e negros. Diante dos problemas da igualdade política, a autora afirma,

[...] a separação entre quem e o quê é para ser representado, bem como a subordinação do primeiro ao segundo, está em 
plena discussão. A política de ideias está sendo desafiada por uma política alternativa, de presença. (PHILLIPS, 2000, p. 5, grifo do autor)

O embate para garantir a participação das mulheres no movimento é assumido pelas hip hoppers, como se pode acompanhar através do relato de Dina:

Eu acho que é o que todas as meninas enfrentam entendeu? É de você ocupar os espaços, é de mostrar para os caras que aqueles espaços que eles dizem que são nossos, é nosso, não é porque eles estão dizendo, é porque já era nosso, então a maior dificuldade fazer com que eles percebam que aquele espaço já era estabelecido, aquele espaço de mulher no Hip Hop, porque os meninos já vem dando migalhas, faça isso, faça aquilo, nós temos que ocupar aquele espaços, nós temos que discutir relação de gênero naquele espaço, é nosso!.

Assim, esse movimento oportuniza, por meio de suas linguagens, diversas formas de análise acerca das convenções de gênero. Apreendendo a consideração da rapper acerca das "migalhas" dadas pelos meninos, é oportuna a reflexão acerca da questão hip-hop: espaço de contestação das convenções de gênero? 


\section{HIP-HOP: \\ espaço de contestação das convenções de gênero?}

Neste capítulo serão apresentadas algumas interpretações acerca do Hip-hop como um espaço de contestação das convenções de gênero. As hip hoppers descobrem, nesse movimento de caráter masculinista ${ }^{61}$ e masculino,${ }^{62}$ uma "brecha" para a entrada das mulheres e de suas pautas políticas, interessadas em utilizar o aspecto de protesto. Mas será o Hip-hop um espaço de contestação das convenções de gênero? Será esse movimento um instrumento capaz de contestar as normas de gênero estabelecidas?

Sendo gênero uma categoria analítica que atua nas dimensões do simbólico (significados da cultura) e do político, anteriormente exposto por Alinne Bonetti (2003), as convenções de gênero dialogam com esses dois campos, ao passo que orientam os modelos de masculinidade e de feminilidade. Como dito anteriormente,

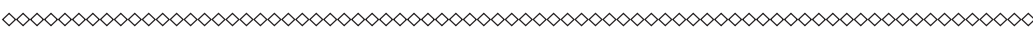

61 Por masculinista entendo três aspectos: 1. Maioria formada por homens; 2. 0 modelo tem referência masculina; e 3. Representa uma assimetria entre o masculino e o feminino (e não entre homens e mulheres).

62 Por masculino, compreendo os atributos que dão significado, a exemplo dos atributos de força, agressividade, astúcia, sagacidade, potência. 
essas convenções não estão ligadas à definição de homem e mulher, mas se configuram na formatação dada pelo repertório cultural que agrega valores aos comportamentos de indivíduos e/ ou grupo.

Para buscar compreender essa questão, tomo como base uma breve reflexão sobre o próprio caráter de contestação social do Hip-hop, ao tentar entendê-lo de forma mais geral, antes de analisar propriamente sua capacidade de contestação das convenções de gênero.

Vale ressaltar a conotação dada ao Hip-hop como um movimento de contracultura, ou seja, contrário à ordem da cultura política vigente. Essa questão foi explicada por Sônia Alvarez, Evelina Dagnino e Arturo Escobar (2000), ao apresentarem a relação entre cultura e política tomada pelos movimentos sociais, devido à criação de uma política cultural que confronte a cultura política hegemônica na sociedade.

O que justifica essa afirmação é, no caso do hip-hop, o contexto histórico, político e social desse movimento em seu momento inicial, e a forma que este tem se configurado em diferentes lugares na atualidade, sob um caráter de contestação social. Conforme mostra Wivian Weller (2000, p. 214), o hip-hop é identificado como movimento que surge nos guetos novaiorquinos nos anos 1970 e que

[...] se expandiu mundialmente, tornando-se uma referência fundamental principalmente para as minorias étnicas na Europa $^{63}$ e para jovens negros, residentes em bairros periféricos das grandes metrópoles da América Latina e África.

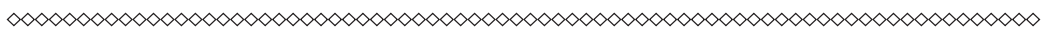

63 A autora cita alguns dos grupos que mantêm esta identificação com o Hip Hop na Europa. Dentre eles, destacam-se "filhos de imigrantes argelinos e afrodescendentes na França, filhos de imigrantes turcos e árabes na Alemanha, afrodescendentes em Portugal e na Inglaterra, e filhos de imigrantes paquistaneses na Inglaterra". (WELLER, 2000, p. 214) 
A autora, que estuda a identificação racial na comparação entre rappers turcos na Alemanha e rappers negros em São Paulo, justifica que a identificação dos jovens turcos ao hip-hop está ligada à identidade de minoria étnica. Já para o Brasil, a identificação dos jovens negros paulistas se dá devido à segregação racial enquanto negros e à segregação social enquanto habitantes dos bairros periféricos.

Dadas as devidas características de expansão internacional do hip-hop, que atua transformando a discriminação vivida por determinados grupos sociais em uma positivação com relação à construção da identidade racial e social, no caso brasileiro pode-se concluir que o aspecto discriminatório torna-se autoafirmação e valorização da identidade para a juventude negra da periferia. Mesmo devido ao compartilhamento, pela juventude, do modelo de hip-hop estadunidense, que é estrangeiro, gringo ${ }^{64}$ ou de fora, este hip-hop "importado" é ressignificado e atualizado, somando elementos locais de cada região específica.

Essa positivação de identidades discriminadas tem sido formulada como uma das estratégias de atuação dos movimentos sociais, especialmente dos movimentos identitários, como os movimentos negros, de mulheres, LGBTT, de juventude, e outros. Ideia que foi defendida por Evelina Dagnino (1994) quando destacou anteriormente que as estratégias democráticas desenvolvidas por todos os movimentos atuam de formas direcionadas pelas dimensões da política e da cultura, ao que se localizam aspectos próprios de cada movimento em relação ao tempo, espaço e contexto social em que estão inseridos.

Dadas as devidas breves considerações para compreender o aspecto "contestação das convenções de gênero no Hip-hop",

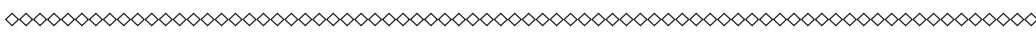

64 "Gringo" é expressão pejorativa utilizada por brasileiros para "coisas do estrangeiro", o que vem de fora do país, importado, de outro lugar. Termo utilizado como crítica à noção colonizadora que prescreve que o que vem de fora é melhor do que o que é nativo - geralmente associada à origem europeia ou "americana", o que demarca uma relação hierárquica entre colonizador-colonizado. 
será analisado, a partir da perspectiva das interlocutoras, suas observações sobre três relevantes aspectos: como se deram seus contatos com o hip-hop - o que lhes despertou o interesse e identificação com esse movimento? O que é hip-hop para elas, e suas definições do que é ser mulher hip hopper.

A forma de contato com o hip-hop da juventude, em especial das jovens hip hoppers soteropolitanas, é que será alvo de interesse desta próxima seção.

\section{A descoberta do Hip-hop}

Aos 33 anos de idade, Dina conheceu o som do hip-hop ao escutar uma música chamada "Um homem na estrada", da banda de rap Racionais Mc. O que lhe chamou atenção foi a mensagem registrada na letra dessa música, que se ritmava sob uma batida da black music de Tim Maia enquanto relatava a realidade de um jovem favelado em sua comunidade com inúmeros problemas sociais.

Na voz de Mano Brown, a música denunciava a trajetória de um homem marcado por crimes, situações perigosas, difíceis escolhas e consequências da sua "estrada" 65 - "Esse é o palco da história que por mim será contada... um homem na estrada". Temas esses comuns às letras de rap produzidas pelos homens e que expõem questões que afligem seu cotidiano, compartilhado pela realidade das periferias em meio ao cenário de criminalidade e luta por sobrevivência diante da violência policial e dos desafios enfrentados por eles.

A fita K-7 com as gravações da banda foi comprada no camelô, embora tenha sido escutada por ela, pela primeira vez, em um aparelho de rádio numa roda de jovens (homens) na rua. Essa

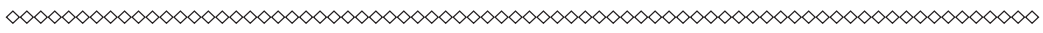
65 "Estrada" com a conotação de percurso da vida. 
música não fazia parte do estilo "músicas que tocam no rádio" em meados dos anos 1990, em Salvador.

Paula, que já gostava de cantar, também descobriu o hip-hop através do rap, em fitas K-7 apresentadas por um amigo, inicialmente com o som de Gabriel Pensador. Ela se questionava se aquele estilo era exatamente rap, até que conheceu o rap de MV Bill. ${ }^{66}$

O primeiro, Gabriel Pensador, é alvo de muitas críticas que questionam sua legitimação como rapper pela comunidade hip hopper nacional, especialmente por esse artista não ter envolvimento com o movimento social Hip-hop e por vender seu trabalho musical à indústria cultural. Em suas letras, Pensador discorre sobre temas como violência urbana e policial, drogas, racismo, mulheres, escola, amizades, dentre outros.

Já o segundo rapper citado, MV Bill, caracteriza-se pela ligação direta com o movimento social (e também com a indústria cultural) e por seus relatos da experiência vivida em sua própria comunidade e bairro de origem, a partir de seu pertencimento de classe e realidade social. Em suas letras e performances, o rapper traz descrições detalhadas de situações enfrentadas em seu cotidiano e compartilhadas pelas periferias urbanas.

Outro critério para o contato com o rapé o fato do acesso a esse produto musical, que não passava pela rádio da mídia comercial, mas pelas mãos de outras pessoas, a partir de uma rede informal de circulação dessa produção artística. A música do hip-hop, nos anos 2000, ainda não circulava de forma ampla, ou mesmo na programação da rádio. Segundo a memória de Carla, de nome artístico Kaia na paz, ela ouvia rap na escola quando trazido pelos

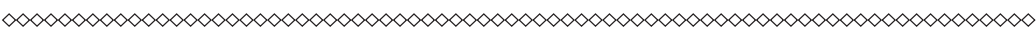

66 No meio hip-hop, algumas vezes, foi destacado por diferentes membros essa distinção entre estilo de rap, o questionamento do reconhecimento da produção do rapper diante de sua relação com a mídia - indústria cultural - e, sobretudo, com o movimento social. Especialmente nesse segundo item, segundo os informantes em conversas e em discussões dos grupos do movimento, a relação com movimentos sociais está mais explícita em relação ao MV Bill com a Central Única das Favelas (CUFA), iniciativa da qual faz parte. 
meninos em fitas K-7 e CD, e não pela rádio, nem em formato de vinil.

É interessante notar nos relatos apresentados das três hip hoppers que todas tiveram contato com o rap por meio de fitas $\mathrm{K}-7$, em aparelhos de som pertencentes a algum "amigo" que detinha o material e o equipamento, além das músicas serem de autoria de bandas compostas por homens ou mesmo de um rapper homem, que mesmo compartilhando questões da realidade da população negra e da periferia falava a partir do seu lugar de homem, com uma linguagem masculinizada, em sua maioria, direcionada para outros homens.

Essas considerações justificam o caráter masculinista e masculino citado anteriormente, o qual o hip-hop apresentava, já que as contestações proclamadas pelo rap circulavam em torno de questões de interesses e de valores que obedeciam a um modelo que tem o "homem" e os atributos de masculinidade como referencial, demonstrando o reforço à convenção de gênero estabelecida.

Entretanto, não foi exatamente com o rap que se deu o contato de Carla com o hip-hop, e sim por um dos mais velhos ou um dos primeiros elementos: o grafite. Era uma expressão que acontecia nos muros das cidades com spray, não era exatamente o grafite, mas aparecia pelas ruas e avenidas, conforme contou Carla:

Perceber o hip-hop, assim, na minha volta já tenho... aí dentre os elementos; o grafite e o rap. Então esses dois elementos do hip-hop eu já tenho um tempo que eu percebo na rua! Na rua, e na minha época quando eu fazia ensino médio, eu tive muito contato com a galera que pichava. ${ }^{67} \mathrm{E}$ essa galera, uma parte dela, virou grafiteiro ${ }^{68}$ e tal. Che-

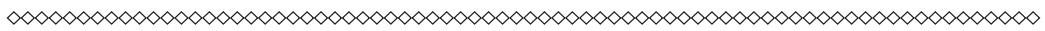

67 Pichação difere do grafite, é reconhecida como poluição visual e violência urbana em relação ao patrimônio público.

68 Distinção entre pichação e grafite está para lixo versus arte. 
guei até a riscar no piche, ${ }^{69}$ coisa bem pouca. Mas era pichação também e era muito massa a sensação de pegar a sua latinha e riscar uma parede, é muito melhor.

A sedução das diversas artes do hip-hop começou a se desenvolver e se exibir pelas ruas da cidade, fazendo com que as jovens pudessem perceber o hip-hop à sua volta, conforme relatado por Carla. Sons, cores, movimentos e estilos surgiram com esses elementos artísticos e ultrapassaram os limites das ruas para adentrarem em instituições ${ }^{70}$ que lidavam exclusivamente com a juventude de bairros populares, e que se utilizavam da arte para trabalhar aspectos da educação e da cidade.

No caso de Carla, essa arte de pintar os muros da cidade também lhe foi apresentada por homens, os quais (alguns) se tornaram grafiteiros, segundo ela menciona. Nesse sentido, alguns pichadores aderiram à arte do grafite após as experiências com a pichação, ampliando seu repertório de atuação. Carla, por sua vez, em outras oportunidades, envolveu-se também com outros elementos do hip-hop, como o rap e o break.

No caso particular de Priscila, ela reconheceu uma pessoa que teria um estilo diferenciado e de referência ao hip-hop com roupas folgadas e livros na mão. Militantes hip hoppers compartilham de um estilo próprio de vestimentas que comumente os diferenciam ou os identificam em meio a outros grupos de jovens, conforme exposto anteriormente.

Priscila conversava com seu então vizinho de bairro, Robson, poeta do rap. O contato com integrantes do movimento também

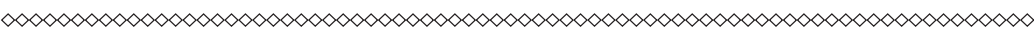

69 Gíria para o ato de pichar.

70 Tais como a Fundação Cidade Mãe e o Centro de Referência Integral de Adolescentes (CRIA), ambas instituições que trabalharam com oficinas, aulas e grupos de arte-educação que se utilizavam das linguagens do hip-hop em suas tarefas didáticas e trabalhos com grupos. Esse foi o caso de pelo menos três das jovens entrevistadas, Negramone, Vivian e Eliciana. Durante o trabalho de campo, tive contato com muitas jovens, mulheres e homens que fizeram parte desses trabalhos e instituições. 
foi um aspecto apontado pela maioria das entrevistadas, como convite de amigos e amigas, pessoas já pertencentes ao hip-hop. Ela conta que Robson estava de posse de um fanzine ${ }^{71}$ do movimento Hip-hop e sugeriu que ela tirasse uma cópia do material contendo informações sobre a Rede hip-hop da cidade e sobre os encontros realizados por eles naquele período. O interesse em produzir sua própria mídia e contar sua própria versão da história são características promovidas pela mensagem do "Faça você mesmo!”, em inglês “Do it yourself!”, que traduz a noção de independência e atitude passada pelas gerações hip-hop.

Como exemplo em circulação na época, tem-se a segunda edição do fanzine "Zine Hip Hop em movimento" produzido em 2002 pelo movimento Posse Ori, com o título "Fracasso é desistir de continuar lutando". Esse fanzine contou com o apoio do Diretório Central de Estudantes (DCE) da Universidade do Estado da Bahia (UNEB) e foi formatado em uma folha de papel A4 impressa nos dois lados, dividida em quatro partes, e apresenta uma série de informações que discorrem sobre os elementos do hip-hop, além de uma seção para tratar do skate ${ }^{72}$ como arte e esporte. Nesse material também há a agenda de atividades do movimento e informações sobre posses e grupos da cidade, bem como entrevista com militantes artistas e questões que passeiam em torno do universo masculino do hip-hop.

Essa noção de autonomia tornou-se praticamente um lema do movimento, que afirma a identidade do grupo enquanto este produzia seu próprio material midiático. Posteriormente, essa comunicação do movimento produziu informação em dimensão virtual e tecnológica, adentrando nos espaços da internet e criando uma nova linguagem e formas de diálogo entre movimentos. São os

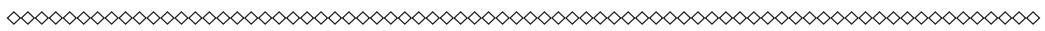

71 Espécie de revista ou jornal informal e alternativo produzido pelos grupos do hip-hop, com caráter de impressa independente e autônoma do movimento. Como exemplo: ZINE Origens. Posse Ori Movimento Hip-Hop. Salvador, n. 4, 2004.

Em muitas oportunidades, o skate aparece articulado às artes e à militância do hip-hop.
} 
exemplos de blogs e sites, listas de discussão, e-mails, comunidades virtuais, redes sociais, entre outros, que promovem novas formas de contatos, como apontaram Santos e Sunega (2009).

A divulgação de informações sobre o movimento por parte de seus militantes se manteve, realizada pelo modo alternativo conhecido por "boca a boca", e por contatos informais. Essas práticas construídas pelo movimento Hip-hop apresentadas acima, e compartilhadas por outros movimentos sociais, foram identificadas por Dagnino, Alvarez e Escobar (2000) como desafiadoras dos sujeitos e das práticas hegemônicas, capazes de resignificar interpretações culturais dominantes da política. Nesse caso, tem-se o exemplo dos fanzines ${ }^{73}$ produzidos pelo hip-hop, que podem ser vistos como meros "subprodutos" pelos membros do sistema dominante, mas que são produzidos pelo movimento social como produtos culturais de contestação.

Esses produtos culturais são resultados de esforços ativos na luta política, e redefinem sentidos e limites à cultura política local. É o que defende Edér Sader (1988) ao analisar que mesmo os pequenos atos, como a circulação de um fanzine ou outra atividade, demarcam a participação e contribuição de um determinado grupo sobre as questões em discussão na sociedade em que vivem. Essas ações reafirmam a posição de resistência e criatividade de sujeitos políticos, independente de seu alcance institucional estatal.

O Hip-hop é reconhecido por diversos segmentos políticos como um movimento contestatório das desigualdades sociais. Essa posição de protesto e denúncia já foi apresentada, especialmente pelo elemento rap, no caso, o rap militante, que se utiliza de críticas sociais para fomentar questões de autodefesa e visibilizar

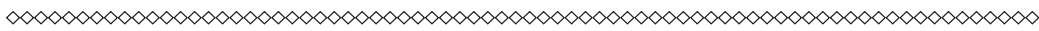

73 Fanzine tem caráter de um minijornal não profissional, interessado em circular por um público alternativo, a exemplo dos punks, que utilizaram de forma ampla essa estratégia de comunicação informal em seus grupos. 
o debate público de importantes questões sociais. Angela Souza (1998, p. 45) cita o rapper estadunidense Chuck-D que nos anos de 1980 chamou o rap de "CNN da rua", ${ }^{74}$ pois, segundo a autora, "informa, educa, faz rir, às vezes amedronta".

Como um dos exemplos soteropolitanos desse tipo de rap, trago um trecho da letra da música "Quadro Negro", da banda Simples Rap'ortagem, de autoria do rapper Jorge Hilton, acerca do debate sobre a política de ações afirmativas através das cotas no ensino público superior, tema pauta do movimento hip-hop soteropolitano.

$[\ldots]$

Se na prova der branco na memória

Vamos denegrir a sua mente com a nossa história

A luz do sol ofusca a visão

E a beleza da lua só possível com a

Escuridão

A luta pelas cotas não anula a luta pela melhora

Da qualidade de ensino público, tu ignora

Pelo contrário, quanto mais negros na academia

Muito mais força pra se lutar por um novo dia

Racismo, o que mais me causa espanto

Não se encara como problema do branco

Mas entre esses, há os que lutam pelo seu fim

'Ah se todo branco fosse assim'

Branquitude, pouco se ouve falar

O que explica o privilégio que sua etnia pode conquistar?

Pra quem nasceu em berço de ouro é difícil entender

Que não é só porque seus pais fizeram por merecer

Foram anos de exploração no passado pra que um dia

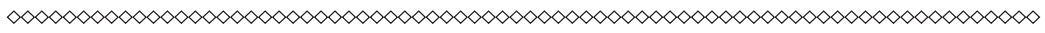
74 Menção a canal televisivo americano. 
A sociedade fosse estruturada a favor de uma minoria

Há os que não admitem cotas, julgando ser injusta

Outros julgando ser esmola, tudo isso me assusta

Pergunto quanto custa superar o engano?

Quanto custa ignorar os direitos humanos?

Muita coisa bonita garante a constituição

Se esquecida ou ignorada precisa de afirmação

Pretos e brancos são iguais, e daí? Se a norma

Nem no cemitério são tratados da mesma forma

Entenda agora o que são ações afirmativas

Medidas pontuais, alternativas

Medidas passageiras que vem afirmar

Pra sociedade, que há, desigualdade, a reparar

$[\ldots]$.

Esse tema foi alvo de intensos debates na sociedade soteropolitana, e aponta para um dos mais importantes aspectos da relação do hip-hop com a juventude, tendo como preceitos fundantes do movimento a preocupação com a educação e a busca por conhecimento.

Carla faz parte da primeira turma de estudantes cotistas da UFBA, representando a conquista de um direito fruto de reivindicações do hip-hop e da juventude negra soteropolitana. Assim, retoma seu relato: "Aí, comecei a ler, e foi daí que começou a despertar uma curiosidade, um interesse da história do Hip-Hop. Daí pra cá eu fui me interessando, me aprofundando mais no assunto". É importante destacar a relevância desse quesito de estímulo ao conhecimento proferido pelo movimento Hip-hop e reafirmado por um dos seus segmentos, a Posse Ori, o que foi registrado no fanzine citado com a mensagem "Informação é poder" (POSSE ORI, 2002).

A partir daí Carla buscou mais informações sobre o hip-hop, seus elementos e personalidades de referência em suas artes no 
país. Ela citou o b-boy Nelson Triunfo ${ }^{75}$ e a curiosidade de saber mais sobre sua história na dança de rua, bem como outros elementos. Vale destacar que as referências de personalidades ícones do hip-hop citadas pelas hip hoppers estão ligadas aos homens que tiveram maior visibilidade nacional no desenvolvimento dos respectivos elementos artísticos, a exemplo de Nelson, no break, e Mano Brown, no rap. Não são citadas referências femininas em relação aos elementos do hip-hop, além das próprias hip hoppers locais.

Já em contato direto com atividades do movimento Hip-hop, algumas jovens tiveram a oportunidade de participar de encontros, reuniões e eventos, muitas vezes, convidadas por amigas e amigos. Esse foi o caso de Mônica, que participou do Encontro de grafite e Hop-hop, em 2005, e decidiu começar a grafitar e abrir espaço para as mulheres nesse ramo. Ela coloca que:

É saber que assim, até porque depois que eu comecei a grafitar eu não procurei saber quando surgiu o grafite, de onde o grafite vem, eu nem sabia que o grafite era o quarto elemento do hip-hop. Com o grafite é que eu passei a conhecer isso, então isso me fez perceber que eu era parte do elemento do hip-hop.

Esse exemplo aponta para a distinção entre desenvolver uma das artes do hip-hop, seja qual delas for, e ser parte do movimento, atuando de forma a intervir positivamente em suas discussões e atividades. Essa afirmação remete à consideração de que apenas um elemento isolado não constitui o hip-hop. É na soma desses elementos que se compõe o que é conhecido por hip-hop.

Quando a grafiteira apenas se dedicava à prática do grafite, sem sequer saber a história do elemento do qual desenvolvia, ela não conhecia o hip-hop, "eu nem sabia que o grafite era o

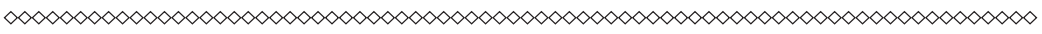

75 Nelson Gonçalves Campos Filho, nascido no sítio Caldeirão, em Triunfo, Pernambuco, em 28 de outubro de 1954. É um ícone do break, considerado na história do hip-hop como o mais importante $b$-boy no país. 
quarto elemento do hip-hop". A partir de seu aprofundamento no conhecimento sobre o hip-hop, ela percebeu que "era parte do elemento do hip-hop", e, consequentemente, que havia uma demanda de ações vinculadas ao hip-hop como movimento social, as quais ela poderia conhecer e contribuir.

Contudo, o caso de contato com o hip-hop por Eliciana apresentou-lhe a chance de um breve panorama histórico; permitiu-lhe não apenas mostrar um caminho da cultura musical negra que se desenvolvia no cenário alternativo soteropolitano antecedente ao hip-hop, como também expor a conotação realmente contestatória que o hip-hop assumiu em relação a outras expressões culturais, em especial, expressões da cultura musical negra.

O que identificou o cenário da cultura black alternativa e musical nos anos de 1980 foi o funk. Precedente ao hip-hop, o funk abriu caminho para as posteriores culturas negras que acompanhassem estilos modernos e tecnológicos inspirados no blues e jazz.

ELICIANA: Já, eu não me lembro a idade que eu tinha, acho que eu tinha de 10 a 11 anos de idade. Eu fazia parte de um grupo que a gente chamava de Funk, Cobra, girls. Na época era o primeiro grupo de funk de mulheres que existia aqui em Salvador, não existiam outros. E a gente ia geralmente pro baile funk do Black Bahia, que já existia desde a década de 80 lá. Antes acontecia no Esporte Clube de Peripiri e agora esse clube foi comprado por uma igreja e acontece no Clube Flamenguinho, que é do lado.

Segundo Osmundo Pinho (2005), em seu estudo "Etnografia do Brau", o funk chegou em Salvador no ano de 1979 a partir do baile Black Bahia. Esse baile, que ocorre até os dias atuais, se mantém sediado no Esporte Clube Periperi, localizado em uma das regiões mais empobrecidas da cidade, no bairro do subúrbio 
ferroviário homônimo. O baile foi organizado por Mauro Xavier e Petrúcio, ambos cariocas com experiência com soul music no Rio de Janeiro, onde já havia se expandido a cultura funk.

Entre esses grupos de dança citados pela hip hopper, destaca-se o grupo feminino Cobra funk girls, composto apenas por meninas, único grupo referido com essa característica, que se contrapunha ao grupo Cobra funk boys, composto apenas por meninos. Eliciana foi uma de suas integrantes, quando tinha 11 anos de idade.

Só existiam grupos de homens, era o Funk boys; era o Funk cobra, que foi dai que originou o nosso grupo, porque um rapaz do Funk cobra resolveu dar aula pra gente, o MC Maxixe, ele resolveu dar aula de funk pra gente. No começo era eu, minha irmã Eliana, três vizinhas nossas, Daiana, Rebeca e Flávia. E a gente começou a treinar e fazíamos os mesmos passos do Funk cobra. Até que a gente começou a evoluir, porque a gente ia pro baile funk, que só tinha homem, tinha aquele momento em que fazia os passos coreográfados, que todas as pessoas acompanhavam, aquele passo de galera, o chamado passo de galera, que todo mundo dançava, ia pro lado, ia pro outro lado e tal e tinha um momento que abria a roda, a famosa roda de break, que lá já acontecia, e a galera do funk dançava e geralmente eram só homens. E aí, quando surgiu o nosso grupo, que a gente começou a ensaiar, a gente ensaiavadireto, inclusive a gente sem perceber tinha cultura, uma cultura que era cultura da origem do hip-hop, que é instalar o som na rua, no meio da rua lá de onde a gente morava em Periperi e ensaiava. E de repente reunia várias pessoas da vizinhança e começava a assistir a nossa apresentação, que era um ensaio, que a gente ensaiava pra porra dentro da garagem de uma colega e quando a gente tinha uns passos legais à gente ia pra rua. 
Eliciana relatou que, a partir do amadurecimento do grupo, as meninas começaram a mostrar suas coreografias e a abrir mais espaço para as mulheres na pista de dança do baile. Naquele momento já se apresentavam alguns elementos que futuramente se configurariam elementos artísticos que comporiam o hip-hop, embora ainda não se pudesse ser assim chamado. Uma das principais atrações do baile funk, por assim dizer, eram os grupos de dança, que segundo Pinho (2005), geralmente nomeados por "cobra", "dragão", e "fera”, dançavam uma espécie de break. O rap também já era reconhecido naquele espaço como estilo musical, mas era a dança o elemento de maior destaque.

Conforme apresentam Pinho (2005) e Eliciana (2005), o universo masculino do hip-hop já se constituía nesse momento em predominância do funk, com referências aos atributos de masculinidade. Esses atributos eram demonstrados, por exemplo, a partir da vinculação dos nomes de animais selvagens e bichos imaginários que conotavam, juntamente com os quesitos para as práticas dos exercícios, aspectos de força, violência e agressividade, reafirmando o reforço à assimetria de gênero nesse contexto.

Segundo o autor, havia equipes de dança inicialmente treinadas por Mauro Xavier a partir do ano de 1982, entretanto, apenas em 1987 o baile realmente "pegou fogo". O preparo físico e os passos cronometrados com muito ritmo e sensualidade eram devidamente estudados pelo grupo, sendo que alguns se preparavam para apresentações e competições.

Para Eliciana, o funk foi uma ponte para se envolver com movimentos artísticos em contato com a dança e também com a música, no caso, o rap, e com ideias críticas sobre as questões sociais. No espaço do hip-hop durante o trabalho de campo foi possível ouvir algumas memórias do início da cultura negra alternativa nesse baile Black. 
Assim chamado black por assumir uma identidade negra sob aspectos políticos e culturais que se expressavam nesse baile de diversos modos: nos visuais dos cabelos e roupas, estilos de dança, na ambientação do lugar, com decoração inspirada no estilo disco music (música a partir dos discos de vinil), do qual aderia à cultura jovem que acontecia na época. Além disso, entre os principais hits tocados na época estavam James Brown, Jorge Benjor e Tim Maia.

Entretanto, havia um diferencial entre o funk e o hip-hop. Um caminho trilhado pela geração hip-hop que se constituiria em Salvador, que diferencia ou descreve o trânsito do funk para o hip-hop, como explicou a Eliciana:

Ai através disso eu fui conhecendo outras coisas, o teatro, a poesia, o hip-hop e aí comecei a tomar consciência de que esse funk de que eu fazia parte em Periperi, não fazia revolução, não fazia muito impacto social. Porque por mais que eram mulheres dançando, que era um diferencial entre homens, não tinha uma questão politica, era uma coisa muito mais da felicidade. [...] no geral era uma cultura muito mais da felicidade, que a gente, no final de semana, colocava uma roupa deferente, as meninas faziam uma coisa de figurinos deferentes, iam pro baile e tal chamar a atenção, mas não tinha uma coisa política mesmo. E aí depois que eu conheci o [MIACC],76 teatro, esses movimentos, eu vi que tinha um movimento muito mais forte efervescendo na cidade que o funk não tinha.

$\infty<\infty<\infty<\infty<\infty<\infty<\infty<\infty<\infty<\infty<\infty<\infty<\infty<\infty<\infty<\infty<\infty<\infty<\infty<\infty<\infty<\infty<\infty<\infty<\infty<\infty<\infty<\infty<\infty<\infty$

760 Movimento de Intercâmbio Artístico Cultural pela Cidadania (MIAC) atua em Salvador, trabalhando com adolescentes e jovens, com projetos de arte-educação pela cidadania. Alguns jovens conheceram o Hip-hop e seus elementos em atividades de teatro, dança e música através desse movimento. 
Essa cultura da felicidade, da festa de dança, passou a ilustrar mais uma realidade descomprometida com os problemas enfrentados pelos jovens naquele momento, especialmente para quem tinha origem nos bairros das periferias e de identidade racial negra. Entretanto, o espaço do funk era propício para proliferação de outra cultura negra que chegava dentro do mesmo movimento global do qual o funk chegou, porém com o bojo mais crítico acerca do cotidiano dessa juventude.

Essa nova cultura que chegava e se aportava nesse ambiente era o rap, elemento conhecido como o grito ou voz do gueto e dos injustiçados. Ele é o exemplo desse trânsito do funk para o hip-hop, utilizado por Eliciana.

Eu me lembro de um único momento, um dos únicos momentos políticos e fortes que eu vivi dentro do funk foi quando a gente sempre ia pros baile funk de Paripe, Plataforma, onde tinha baile funk, a gente ia e a gente às vezes não tinha grana pra ir, ia andando e voltava andando até Periperi, com uma galera. E tem um colega nosso, Maxixe, que foi precursor do nosso grupo, que fundou o nosso grupo com a gente. Ele perdeu um irmão que foi baleado e quando chegou na frente do hospital, não deixaram atender ele, porque acharam que ele era $o$ bandido, a polícia parou a frente do hospital achando que ele era o bandido e ele acabou morrendo por causa disso. E ele fez uma rap sobre essa história. E a gente, como vinha andando do baile, fazendo festa, cantando pela rua e tal, a gente parou um dia de madrugada todo mudo cantando que voltou do baile funk e parou na frente do hospital, todo mundo e começou a cantar esse rap lá, fazendo protesto sobre a forma de discriminação que aconteceu lá no hospital e que levou a morte do irmão dele. E aí assim, foi o único momento forte e político que eu vi dentro do funk $[\ldots]$. 
Nesse momento relatado, o rap foi utilizado como uma arma de reivindicação, reconhecido como um instrumento de protesto. Para Weller (2000), o rap é um instrumento de informação e mobilização das juventudes negras dos bairros periféricos, criando uma forma de enfrentar a exclusão a partir da valorização da história e da cultura da população negra. Segundo os informantes da autora, identificam o rap por sua característica de ser direto ao produzir uma música de denúncia e de protesto da exclusão cultural e social, da violência policial e da discriminação sofrida.

Com a distinção entre o funk e o hip-hop, essa juventude questiona o político e a cultura, na busca por ferramentas e armas que possam ser usadas em seu favor. Como mostraram Evelina Dagnino, Sonia Alvarez e Antonio Escobar (2000), o laço que une o político à cultura permite o reconhecimento da significação das relações de poder estabelecidas nas expressões e práticas sociais. Ambos, política e cultura, mutuamente interferem e constituem um ao outro, e são capazes de ressignificar concepções alternativas aos significados culturais dominantes. O hip-hop se constituía com esse objetivo, a fim de reunir ambos os aspectos do político e da cultura para dar voz a possíveis transformações sociais de baixo para cima, prestigiando as estratégias de enfrentamento das desigualdades. Entretanto, esse movimento é desafiado diante de como se comporta quando se trata de desigualdades de gênero, conforme apontam as experiências apresentadas.

Entre os achados do campo, surgiram breves, mas consideráveis observações, entre outro estilo musical-cultural negro relevante no cenário artístico baiano que teve influência no contato das jovens com o hip-hop: o pagode. Ritmo oriundo do samba, famoso não apenas por suas batidas dançantes, mas, sobretudo, polêmico por suas letras que difamam as mulheres e satirizam seus corpos. 
Dina falou sobre o fundo musical da mesa de abertura do Seminário, o qual tinha um som alto de pagode vindo das imediações do local. Ela, que foi a primeira das convidadas a falar, abriu sua intervenção com gestos que apontavam para que as pessoas presentes prestassem atenção na música tocada em alto volume naquele momento pelos vizinhos da ocupação do Movimento dos Sem-Teto da Bahia (MSTB), no imóvel abandonado no centro da cidade, ao lado do local onde acontecia o Seminário.

As pessoas da plateia ficaram atentas enquanto a maioria fazia gestos de reprovação ao som daquele estilo musical. Ela iniciou sua fala afirmando o quanto o hip-hop tinha por fazer em Salvador. O debate assumiu o foco de construir uma oposição entre o pagode e o hip-hop, mas que logo tomou um rumo mais crítico e preocupado com a relação desses dois estilos musicais, a partir do lugar das mulheres dentro do rap, no hip-hop e na sociedade.

Dina afirma que muitas mulheres que hoje estão no hip-hop já foram adeptas do pagode, pagodeiras, e cita o exemplo da rapper Negramone, que também compunha a mesa em questão. Ela segue apontando distinções em relação à aparência e ao próprio comportamento da colega nos diferentes momentos de sua vida, destacando desde uma transformação visual do cabelo, antes alisado por produtos químicos, e umapreocupação excessiva com a sensualidade expressada na dança, - quando esta frequentava e vivia uma cultura vinculada ao samba e ao pagode - até a sua transformação após o contato com o hip-hop. Dina afirmou que ficava feliz ao ver a colega que assumiu sua identidade de mulher negra e passou a retratar sua realidade em letras de rap, envolvendo-se cada vez mais com o movimento. Ela verbalizou apontando que a partir desse exemplo pôde ver a força de transformação do hip-hop, de como pode interferir na vida das pessoas. (Diário de campo, 14 ago. 2010)

A questão central de preocupação apresentada pelas hip hoppers no Seminário estava associada à imagem das mulheres produzidas por ambos os estilos musicais, rap e pagode. Ambas 
as produções musicais, em sua maioria, compartilham a reprodução de um estereótipo que submete a imagem feminina a ter seus corpos tratados como objetos sexuais e reprodutivos, os quais sofrem um desprestígio, sobretudo acerca dos corpos das mulheres negras, em que age o aspecto da discriminação racial.

Em entrevista, a grafiteira Mônica assume que gosta de pagode, que gosta de sair para dançar, e que mesmo depois que entrou no hip-hop não deixou de ser pagodeira. A ideia de que o hip-hop se relaciona com tudo, inclusive com distintos estilos musicais, é expressa nesse exemplo, evidenciando que hoje há uma diversidade complexa dentro desse movimento.

Quando questionada sobre o que ela entendia por hip-hop, ela riu e brincou, dizendo que era mais do meio do pagode, que gostava de sair para dançar axé e pagode. Para a maioria dos seguidores do hip-hop, essa relação da grafiteira com o hip-hop e pagode seria, no mínimo, contraditória. Essa informação a respeito de Mônica não tinha sido discutida na mesa de debate, foi relatada apenas durante a entrevista individual, mas sem que houvesse nenhum pedido de restrição. Segundo Mônica, apenas recentemente ela compreendeu a ideia de união e amizade em torno do movimento. Desde então, ela se empenha para aprender mais sobre o hip-hop e sua história, interessando-se em contribuir com suas atividades. Na oportunidade, ela diz estar conhecendo o hip-hop ou outro tipo dele naquele Seminário, junto com as mulheres.

À procura de novo espaço de atuação jovem, as mulheres encontraram uma "brecha" para sua participação no movimento Hip-hop. Contudo, a partir das intervenções dessas militantes, se constituem as pautas e as bandeiras que orientam suas prioridades e as formas de ações dos grupos e indivíduos. Essas pautas são construídas pelas mulheres integrantes desse movimento, as quais muitas vezes reúnem seus interesses em questões comuns. Entretanto, há espaço para as questões das mulheres nesse 
movimento? Há uma "brecha" para a transformação da convenção de gênero?

\section{"Brecha" de entrada das mulheres no movimento Hip-hop}

A fim de problematizar a noção de "brecha" para as mulheres no movimento Hip-hop, tem-se o questionamento: essa "brecha" foi cedida ou foi conquista por elas?

No Seminário Coisa de menina, a fala de Dina, descrita anteriormente, destacou a preocupação direcionada para realidade vivenciada pelas mulheres negras pobres que estão à margem da sociedade. Entretanto, segundo explicou Dina, algumas mulheres passam por um processo de transformação de consciência e de comportamento político ao terem oportunidade de contato com outros movimentos sem que seja preciso que estas, necessariamente, estejam vinculadas a algum partido político para questionar seu lugar na sociedade.

Contudo, a relação entre mulheres e hip-hop tem sido cada vez mais explorada pelas militantes como um novo espaço de atuação política feminina. Mesmo com caráter masculinista, o hip-hop tem se apresentado como espaço interessante para inclusão de novas pautas, inclusive específicas sobre as mulheres e de interesse das mulheres. É o que relata Dina quando questionada sobre a escolha do espaço do movimento Hip-hop como espaço para sua atuação e de outras mulheres:

Ao mesmo tempo em que a gente tinha dificuldade de atuar, foi o movimento que deu essa brecha, que dá essa oportunidade. Porque o movimento hip-hop dialoga com tudo, tudo que não está dentro do contexto, entende? Agora só precisa perceber a abertura que nos dão. E eu percebi, nós mulheres sempre percebemos as coisas um 
pouquinho mais que os homens, né? E eu percebi que o movimento ele te dava, mecanismos para você realmente questionar e dizer as coisas até o fim. Então é essa abertura que o movimento dá mesmo.

Esse interesse no hip-hop se dá pela abertura desse movimento em discutir temas atuais, "porque o movimento hip-hop ele dialoga com tudo”, como afirma Dina acima. Sobretudo, ele age de forma a compartilhar reivindicações em torno de mudanças fundamentais nos privilégios e direitos de diferentes grupos políticos. Devido a isso, o hip-hop foi reconhecido pelas mulheres como "um movimento que dava essa brecha", como mais um possível espaço de mobilização social, "ele te dá mecanismos para você realmente questionar e dizer as coisas até o fim".

Sendo assim, a partir da fala da rapper, pode-se interpretar que o movimento Hip-hop, interessado em debater e agregar diversos temas vigentes na sociedade, permitiu como que numa "dádiva" a entrada dessas mulheres, a fim de incluir em mais este mote a sua pluralidade de representações. "Brecha" pode ser entendida como uma pequena abertura ou passagem, mediante autorização para permanência nesse espaço político. Soa, também, como uma concessão dada pelos homens, por ser um movimento majoritariamente composto por homens - deram às mulheres a oportunidade de estarem presentes, sem necessariamente influenciarem ou mesmo que estas sejam reconhecidas como cabíveis de decisão em torno do coletivo não apenas de mulheres, mas do movimento como um todo.

Em sua fala, Dina reforça a ideia de que o hip-hop pertence aos homens, e reafirma caráter masculino e masculinista do movimento, dotado de atributos de gênero e poder, os quais posicionam o feminino de uma forma inferiorizada. As demandas por espaço de discussão e formação política das jovens soteropolitanas no 
movimento social se proliferavam em torno de questões diversas sobre raça, gênero, juventude, sexualidades, trabalho, educação, meio ambiente e outras. O movimento Hip-hop apresentava-se como essa brecha para a entrada da juventude e das mulheres jovens, em especial. É o que compartilhou Negramone:

Eu entrei no hip-hop porque eu me percebi dentro daquele universo, percebi que eu poderia tá colocando as minhas questões sobre a sociedade em que vivo baseada e conectada com outras maneiras de manifestação. Foi direcionado com esse objetivo de perceber um movimento aberto, movimento que eu poderia discutir as minhas relações.

Formado por pessoas e lugares urbanos, o movimento se mostrava presente nos espaços da cidade, em atividades frequentes. Segundo ela, "eu pude conhecer mais a dimensão do que é o movimento Hip-Hop e me interessar por ele, muito por essa questão social e política de engajamento na sociedade, que é além da manifestação das artes”. É a partir desta conexão entre "manifestação das artes" e um espaço para colocar questões sobre a sociedade em que se vive que foi se tornando o hip-hop um lugar privilegiado e cada vez mais interessante para as mulheres jovens. Esse caráter de engajamento identifica a conotação de contestatório da ordem estabelecida pela cultura política local.

Essa afirmação foi defendida por Dagnino, Alvarez e Escobar (2000) quando colocam que a política cultural produzida pelo movimento social interfere no que seja dado como poder social hegemonicamente estabelecido. Reivindicações de mudanças nas estruturas sociais tomam voz em suas expressões artísticas "colocando os dedos na ferida”. Segundo Eliciana, ao participar do II Encontro Estadual de Hip Hop, em Vitória da Conquista, em 2004, as hip hoppers perceberam a necessidade de uma 
organização ou da criação de um espaço específico para que as mulheres tratassem de forma direta sobre suas questões, preocupações e pautas. O resultado foi o fortalecimento do movimento de mulheres inserido no movimento Hip-hop com a criação dos núcleos de mulheres nas posses mistas e a realização do III Encontro Estadual de Gênero e Hip-Hop no ano seguinte. Sobretudo, experiências como essas fortaleceram os questionamentos das próprias hip hoppers em torno do Hip-hop como espaço de contestação das convenções de gênero.

\section{Um espaço para contestação?}

PESQUISADORA: O que é hip-hop para você?

DINA: Hip-hop é atitude, é determinação, autogestão, autonomia, é vida, hip-hop é vida!

PESQUISADORA: E ser mulher no hip-hop?

DINA: É quebrar paradigmas, ser mulher no hip-hop é quebrar paradigmas da estrutura mesmo.

Segundo Dina, o hip-hop é um espaço de atitude das jovens, de positivação da atitude destas, de fortalecimento para enfrentar os desafios e as situações de discriminação e de luta por cidadania. Essa positivação perpassa múltiplos temas de sua vida cotidiana, sobretudo, no que tange à sua visão de mundo acerca dos modelos da masculinidade e da feminilidade. Ao serem interpeladas sobre o sentido do hip-hop, as rappers Paula e Carla compartilham a escolha da palavra "resistência": forma de resistência e luta por liberdade remetendo às experiências de vida da população negra. Carla coloca: "Acho que a liberdade está dentro da resistência quando você luta contra todo um sistema que te coloca, que quer 
te colocar de uma forma, te oprime enquanto mulher, enquanto negra". Já para Paula, "É uma maneira que a gente tem, que a gente continua tendo, nós povo negro, mulheres negras, homens negros, continuamos tendo de resistir, culturalmente, ancestralmente, ideologicamente”.

Dentre os aspectos que se destacam sobre o que é hip-hop, está a união da arte e da política, que conotam mudança na própria cultura política e nas formas de participar. Eliciana apontou que o hip-hop para ela "é um movimento forte, político, de transformação social, um movimento artístico primeiramente, porque são artistas”. Assim, a arte é vista como um meio de transformar a realidade de forma engajada, como visto anteriormente. Esse sentimento e sensação de transformação foi identificado por Vivian ao pensar sobre a mulher que ela era antes e depois do hip-hop e aponta para uma questão a ser posta acerca de sua postura em relação às convenções de gênero no movimento.

Eu tenho certeza que a mulher que eu fui... que eu era até mesmo sendo do 'CAMA',77 que já trabalha a questão racial a questão de gênero, e a mulher, em 2003, a mulher que eu sou hoje em 2008 é totalmente diferente. Acho que uma mulher com autoestima, apesar de que às vezes a peteca cai mas está ali o hip-hop pra não me deixar cair; a questão da auto-estima, do ser mulher. Acho que onde eu me sinto a vontade em me expressar sem medo de errar, nem mesmo de estar falando errado. Se eu tiver falando errado, não importa. É com os erros que a gente aprende também.

A preocupação com a autoestima ${ }^{78}$ é uma questão central para as mulheres, especialmente quando considerado o aspecto

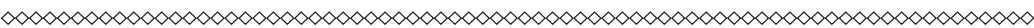

77 Centro de Arte e Meio Ambiente (CAMA), sediado no bairro do Uruguai, em Salvador.

78 Por autoestima compreendo o estilo, a autoconfiança, a aceitação e a valorização de si mesma. 
racial, no caso das negras, questão frequentemente discutida no hip-hop. Essa discussão de autoestima pode ser interpretada pelo reforço às convenções de gênero que reafirmam os atributos de beleza e vaidade como necessários às mulheres, sem questionar, por exemplo, esses atributos em relação aos homens.

Para tanto, essa positivação da identidade feminina, como mostrou Weller (2000) em relação aos jovens negros e turcos, pretende positivar sua condição de mulher, enquanto que os homens não tocam nesse tema como exatamente uma preocupação da masculinidade, o que aponta para uma manutenção, e não contestação dessa convenção de gênero. Entretanto, o hip-hop possui todo um mote de potencialidade para transformação social que pode ser oportunamente direcionado. É o que aponta a fala de Negramone sobre o tema que toca no poder de transformação social do movimento:

Porque a gente não modifica de um dia a outro, mas é criar estratégias pra que a gente possa sobreviver dentro dessa sociedade. [...] mas acho que a importância mais é de eu ter esperança que várias mulheres possam viver outras coisas.

É a partir desse sentimento de transformação do eixo no qual se manifestam as convenções de gênero que o movimento de mulheres do hip-hop reformula novos caminhos para uma reorientação dos modelos de feminilidade e de masculinidade. Para Carla, as questões vivenciadas pelas jovens são problematizadas dentro do movimento e através do hip-hop:

Eu acho que para além da música tem uma coisa que é minha movimentação de conversar, eu acho que uma visão de mundo diferente a partir do momento que eu tenho contato com o hip-hop e entendo o que é hip-hop. Então é muito nesse sentido de grupo, de grupo, de coletivida- 
de. Nunca penso o hip-hop como coisa individual, sempre penso como coletividade. [...] Eu acredito que... É... A partir do momento que eu começo a me perceber e saber que eu faço parte do movimento hip-hop eu acho que muda completamente a minha visão de mundo. Não sei, eu acho que é um espaço, de poder, um espaço de poder e que isso reflete em todos os aspectos de minha vida. É... Tudo. A família. Os conflitos que a gente tem na família, na faculdade, então eu acho que o, o movimento hip-hop influencia nesse sentido de me fortalecer mesmo. É uma troca. Não sei, é tudo ao mesmo tempo. Eu fortaleço o movimento, o movimento me fortalece, então é uma troca constante.

Aspectos que envolvem a abertura para novos aprendizados com a coletividade, a descoberta de uma nova visão de mundo, o sentimento de troca entre indivíduo e movimento, fundamentais para a compreensão do poder de intervenção do hip-hop, mas não são diretamente questões que garantam que nesses espaços haja contestações em relação às assimetrias de gênero. Para que isso ocorra seria necessário um olhar voltado para as relações de poder estabelecidas entre os modelos vigentes, e um olhar voltado para o próprio movimento.

Como produto cultural produzido por essas hip hoppers, suas criações vinculadas aos elementos do hip-hop têm propagado suas inquietações em torno desses modelos previamente estabelecidos para suas vivências de gênero. No caso do rap, a voz do hip-hop, suas letras têm sido porta-vozes na denúncia das discriminações vividas pelas próprias rappers que cantam suas experiências, baseadas em suas reflexões e propostas de alternativas, criadas por elas e pelo movimento de mulheres. Carla compartilha a experiência do rap como veículo para seus objetivos da militância. 
O objetivo que eu acho que é assim, através da arte né, conseguir levar todas as questões que a gente discute de gênero, de orientação sexual, de raça; através da arte a gente consegue, a arte é uma ponte muito fácil de chegar ao outro, assim eu acredito, é muito mais fácil de você sensibilizar a pessoa e fazer com que a pessoa perceba todas essas questões através da arte (...) a importância também do hip-hop ser uma ponte que é mais fácil você chegar a outra pessoa, seduzindo, o hip-hop serve para seduzir a pessoa, pra que as pessoas tenham noção daquela discussão. Então o objetivo é a gente passar essa mensagem mesmo para as pessoas.

Nesse momento, a pauta das rappers coloca em debate temas por muitas vezes velados na sociedade e que afligem diretamente as mulheres e seus corpos. Como exemplo da voz musical das hip hoppers, apresento duas letras de rap produzidas pela banda Munegrale, banda de rap composta apenas por jovens soteropolitanas. Os dois raps referidos tratam de composições das autoras e cantoras, as rappers Simone Gonçalves Santos, Elísia Maria de Jesus Santos e Carla Cristina dos Santos Jesus (formação da banda no momento da pesquisa). ${ }^{79} \mathrm{O}$ primeiro rap trata da música "Levante a cabeça" (NEIM, 2005), que discorre sobre o tema violência contra as mulheres.

Aí mulher você que é violentada

E quem aqui nasceu pra levar porrada

de nenhum homem ou de qualquer mulher Interfira nessa ideia mais rápido que puder

Conquiste seu direito de cidadã

Não deixa o que você pode fazer hoje Para manhã

Não deixe as lesões corporais te atormentarem

E as ameaças mentais se agravarem

Mesmo que surja de dentro do seu seio familiar

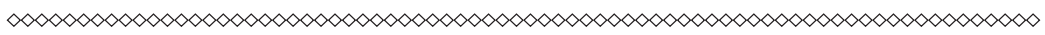
79 A banda Munegrale continua ativa, porém com outra formação. 
O importante para sua vida é denunciar

Ande, estufe o peito, olhe para frente

Vá a delegacia mulheres, faça diferente

Para que outras mulheres possam fazer o mesmo

É em busca de respeito que rompemos o medo

Pois milhares de mulheres estão nessa prisão

E não podemos mais esconder essa situação

Que arranca a liberdade dessas mulheres de viver

E ainda se auto culpa por nascer

Que pensam que os problemas são delas e na verdade

É um sistema cultural de sequelas

Aqui eu vou em busca de respeito

Aqui rompendo o meu medo

Aqui vou levantando minha cabeça bis

Aqui o poder é seu não se esqueça

São vários os motivos que fazem vocês se calar

Dependência financeira, medo, vergonha não dá

Pra se escorar no homem e numa casa

Criem sua independência criem suas asas

Se permitir viver entre tapas e beijos

Antes de você como muito queijos

Humm da raiva quando tratamos desse assunto

Mas não podemos colocar o pano incolor de fundo

Que existem tipos e formas violência

Pessoal, interpessoais, coletiva que tem causas e consequências

Que entre homens e mulheres são diferenciadas

Em quando o homem sofre na rua a mulher sofre pelo homem em casa

Com as desigualdades salarial

Dos assédios sexuais, olhares verbais

É comum que as letras de rap sejam um tanto extensas, descritivas e críticas da realidade vivida. Segundo Carla, uma das rappers da banda, o diálogo que o rap passa para seus ouvintes é importante porque propõe uma alternativa de informação, crítica social e proposta de alternativa para as mulheres transformarem sua realidade. O rap é entoado como que uma conversa entre 
pessoas próximas que compartilham situações e questões similares na vida.

Comparando com as produções dos rappers homens, pode-se perceber que o tema escolhido pelas rappers tem indícios das sanções de gênero, como forma de contestar suas normas tácitas e suas assimetrias. Enquanto a maioria das letras de rap contadas pelos hip hoppers tematizam violência policial e criminalidade, dentre outros, como mostrado anteriormente, as letras das rappers trazem questões sociais vivenciadas pelas mulheres, a exemplo da violência de gênero (GREGORI, 1993; SAFFIOTI, 2001), tema que entrou na "ordem do dia" nas mais diferentes manifestações de mobilizações feministas e de mulheres.

No caso da letra que trata sobre violência contra as mulheres, a mensagem principal objetiva estimular as vítimas desse tipo de violência a darem um basta nessa condição de vida. As rappers apontam alternativas de romper essa situação e identificam vários casos e formas de violência contra as mulheres. O rap se coloca no lugar da pessoa discriminada por estar próximo a essa realidade, como explicou Carla:

Então, a importância da minha participação eu acredito que seja é, eu acho que é tipo ta falando de igual para igual, sabe? É... tipo de eu ter mérito de estar num lugar e falar de igual pra igual com uma outra pessoa que também é da minha realidade né. É... Que.. É isso, que também precisa de uma, tipo um 'levanta aí, acorda né!'. Então acho que tem um maior impacto quando vem de uma pessoa que vivencia tudo aquilo, que vivenciou várias coisas também que aquela pessoa tá passando, então eu acho que o impacto é mais forte.

A afirmação de falar "de igual para igual" permite uma aproximação com a realidade vivida e com a personagem daquela 
história, a qual poderia ser a rapper que canta e compõe a música, como pode ser também o relato de uma história apenas conhecida de perto por amigas, colegas e familiares, ou mesmo a partir de uma notícia publicada no jornal, na revista ou exibida na televisão. Nesse caso de Carla, "de igual para igual" remete ao lugar de onde se fala, de quem conhece aquela realidade e que poderia estar vivenciando aquela experiência. O que remete a um processo de identificação e até solidariedade entre mulheres, por compartilharem uma realidade que reforça a convenção de fragilidade e subalternidade moldada às convenções de feminilidade e que são contestadas ao passo que reivindicam outra referência de gênero.

O segundo rap da banda a ser apresentado é intitulado "Eu gosto dela", o qual fala sobre a questão da diversidade e orientação sexual dentro de um contexto de combate a situações de homofobia. Esse rap serviu de trilha sonora e inspirou o roteiro do curta-metragem de cinco minutos que leva o mesmo título da música. ${ }^{80}$

A nossa bandeira é vermelha e cor de abóbora

Amarelo, verde, azul e violeta

De todos os segredos existe um que é fatal

É seu olhar de menina que faz de você mulher sexual

Ninguém venha me impedir de amar você

E impor o que eu devo, olha só, fazer.

Eu gosto dela, Ela gosta de mim

A gente tem um segredo que não tem fim

Eu gosto dela, Ela gosta de mim

A gente tem um segredo que não tem fim

Vivemos disfarçadas no mundo heterossexual

Machista e racista, e ainda por cima, patriarcal

Mas nosso amor é mais forte que tufão

Quebrando essa barreira que homofóbica meu coração

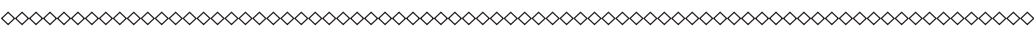

80 Videoclipe que trata das memórias da infância e juventude de uma filha a partir do olhar da mãe afetada pelas representações de gênero dominantes na sociedade brasileira. São abordadas, de forma irônica, as representações heterossexuais hegemônicas e a orientação homossexual. (BARROS, 2007) 
"Eu gosto dela" trata da liberdade de vivenciar a orientação homoafetiva entre duas mulheres que não têm vergonha de sua sexualidade, mas que reconhecem as precauções que devem ser tomadas diante de um contexto de uma sociedade homofóbica. O reconhecimento de uma bandeira deluta é exposto pelas cores do arco-íris, as quais colorem a afirmação de que uma mulher gostar de outra mulher é algo possível e deve ser livre de discriminação.

A autonomia do corpo das mulheres tem sido uma pauta do movimento de mulheres do hip-hop, o qual crescentemente se assume e reivindica reconhecido como movimento de mulheres e/ou movimento Feminista. Será então, o hip-hop, feminista? A partir dessa contextualização e análise acerca dessa amostra do universo do hip-hop, podemos tecer algumas considerações: o hip-hop é um espaço de contestação das convenções de gênero? E mais: há uma brecha para as mulheres?

Diante do contexto estudado, não há uma contestação direta aos modelos de feminilidade e de masculinidade do hip-hop, ou seja, esse espaço (o hip-hop), como um movimento social, não questiona a assimetria de gênero constitutiva do hip-hop. Há uma (re)afirmação de referências masculinas e dos atributos de masculinidade inseridos na perspectiva masculinista constituinte do hip-hop, que inclusive pode ser exemplificada pela ideia de "brecha" para entrada das mulheres, como se fosse uma concessão dos homens.

O que vimos é que se mantém, no movimento, uma separação, por exemplo, ao eleger distintas preocupações para com determinados problemas sociais como que exclusivos de pertencimento ao universo de homens, e outros de mulheres, sem necessariamente alcançar um questionamento acerca dos modelos de feminilidade e de masculinidade no hip-hop. Entretanto, neste texto são vivenciadas questões que representam um mote de reivindicação de participação (PHILLIPS, 2001) dos grupos marginalizados com 
demandas coletivas e específicas, o que ocorre por meio, cada vez mais, da presença ativa das mulheres, que abrem "brechas" não apenas interessadas em visibilização, mas comprometidas em interferir nas pautas que elencam a agenda do movimento. Elas ressiginificam os elementos do hip-hop inserindo suas questões, a exemplo de temas nas letras de rap e outros.

Portanto, a partir das experiências colhidas neste estudo, o hip-hop pode ser visto com ambivalência em relação à contestação às convenções de gênero, pois há uma tentativa de alcançar transformações sociais, mas também de incidir na assimetria de gênero. As hip hoppers ressignificam atributos e valores dados à feminilidade e à masculinidade diante da criação de novas experiências para as mulheres e homens e para o movimento como um todo. Isso nos permite adentrar no debate acerca do diálogo entre hip-hop e feminismo ou mesmo de um "hip-hop feminista", o que nos leva para o nosso último capítulo. 


\section{AGORA OS MENINOS PRECISAM SABER QUE COISA DE MENINA TAMBÉM É COISA DE MENINO! HIP-HOP FEMINISTA?}

Foi apresentada anteriormente a busca de compreender e analisar o contexto em que mulheres jovens entraram em contato com o hip-hop, bem como as motivações e oportunidades para sua inserção nesse Movimento. Foram investigados os elementos e atributos que qualificam o Hip-hop como um movimento de contestação social, refletindo se este é capaz de contestar as convenções de gênero, além de identificar essas convenções dentro do próprio movimento.

O desenvolvimento dessa reflexão trouxe a necessidade de se pensar sobre a possibilidade da existência de um Hip-hop feminista $^{81} \mathrm{em}$ suas possíveis concepções, com vistas a avançar na compreensão acerca do feminismo na sua pluralidade como movimento social, bem como as concepções de feminismo que estão sendo (re)produzidas na prática política dessas jovens mulheres militantes. Aqui há a procura em compreender quais são os possíveis

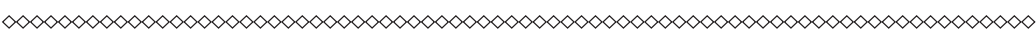
810 termo "hip-hop feminista" surgiu das conversas nas reuniões de orientação com a professora Dra. Katrine Gines (Vanderbilt University). 
diálogos entre feminismo e hip-hop, a partir das experiências cotidianas em torno de questões de raça, militância e sexualidade dentro do cenário do movimento.

Assim, parte-se das premissas de que, como um movimento social, o Hip-hop dialoga com a cultura política local, ao mesmo tempo em que a desafia, ao afirmar pautas e estratégias políticas de reivindicação de direitos e de combate às desigualdades, como mencionado anteriormente. Retomando o conceito de cultura política proposto por Evelina Dagnino, Sonia Alvarez e Antonio Escobar (2000), é a partir da prática de sua política cultural que esse movimento social dialoga com o modelo hegemônico de cultura política, enfrentando e redefinindo os significados das relações de poder configuradas entre a cultura e a política, conforme as experiências apresentadas nos capítulos antecessores.

A pretensão deste capítulo é de perceber, a partir dessas particularidades, como essa militância desafia e (re)significa, em especial, os movimentos feministas com os quais estão em diálogo, partindo da combinação particular de três gramáticas ${ }^{82}$ políticas: movimento Feminista, movimento Negro e movimento de Juventude.

Deste diálogo entre o feminismo e o hip-hop, na perspectiva das mulheres hip hoppers, resultaram diversas relações a serem observadas. Como vimos no capítulo anterior, o hip-hop tem se constituído como um espaço "potencial” de contestação das convenções de gênero para as mulheres jovens, o que remete ao diálogo possível entre esse movimento e o feminismo. Algumas considerações sobre esse debate se impõem quando colocados, lado

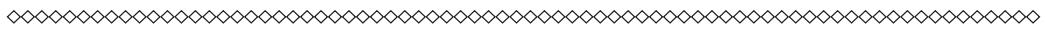

82 A utilização do termo "gramática política" para se referir aos distintos modelos de mobilização política que influenciaram o que procuro denominar como "hip-hop feminista" inspirou-se na análise de Edson Nunes (1997) sobre a gramática política no Brasil. Segundo explicita o autor, a noção de gramática política é "a existência de diferentes combinações culturais e elementos dentro de uma mesma estrutura". (NUNES, 1997, p. 44) Trata-se, assim, do "conjunto de regras mais ou menos tácitas e consensuais de concepções e de práticas políticas, que foi se constituindo historicamente como tal". (BONETTI; FONTOURA; MARINS, 2009, p. 20) 
a lado, hip-hop e feminismo. Ambos compartilham sua origem e trajetória vinculada a "coisas do estrangeiro", o que remete à relação de apropriação pela juventude feminista e negra dos dois movimentos, que compartilham uma referência vinda do exterior, mais especificamente Estados Unidos e da Europa.

Questiona-se, por ambos terem origem no exterior, se tiveram o mesmo tipo de recepção ao aportarem no Brasil e na Bahia pela juventude soteropolitana. Como esses movimentos e suas respectivas ideologias foram apropriadas pelo segmento jovem do movimento social soteropolitano? Essas são algumas questões que envolvem o contexto estudado e que podem ilustrar o entendimento das hip hoppers soteropolitanas sobre a relação entre hip-hop e feminismo. É o que explica a rapper Negramone,

Porque existe a palavra feminista, e se a gente pega só a construção dessa palavra, ela vem de uma outra localidade, de um outro universo de uma outra realidade. Então não é um 'feminista', vamos dizer que é um feminista local, que dialoga como o nacional, o internacional, entende? Esse feminista local a gente pode se dizer que a gente, enquanto juventude, enquanto mulheres, ele existe, mas de uma forma de que como a gente pensa o feminismo, entendendo as suas diversidades, entendendo os seus propósitos e encaixando as nossas sugestões, os nossos objetivos, como a gente quer o feminismo. Não é universal, é como o Hip-hop. O movimento Hip-hop não é universal dentro de uma política de justiça social, racial. Ele existe em suas diversidades, ele tem as suas outras vertentes de filosofia assim como o feminismo, entende? Por isso que gente vai direcionando pra aquele feminismo local, aquele movimento local, mas dialogando com essa diversidade nacional e internacional e entendendo essa diversidade. Porque cada lugar é diferente, por mais que seja a mesma periferia, mas a periferia é diferente, 
cada um tem os seus problemas, cada uma tem a suas questões, violências, cada uma tem o seu jeito de viver.

A rapper aponta diversas questões relevantes em sua fala que ilustram o seu entendimento sobre esses dois movimentos. A primeira se refere ao reconhecimento de um feminismo que está localizado, tem demandas específicas ligadas à realidade de uma juventude que vivencia os problemas de sua cidade e bairro, mas que, ao mesmo tempo, compartilha questões das mulheres de outras localidades. Assim, também foi apontada a mesma característica ao hip-hop, pois ele também pode vir de fora e incorporar questões de outros lugares. Apesar disso, ambos se adaptaram à realidade local da comunidade em que se inserem sob uma motivação e interesse de luta por justiça social, mesmo diante das diferentes vertentes que possam apresentar.

Um importante aspecto a ser considerado é a discussão em torno da origem ou mesmo surgimento e trajetória do hip-hop, como demonstrado anteriormente, que tem se apresentado frequentemente nos diversos segmentos do movimento soteropolitano, como se pode perceber na fala das hip hoppers. Alguns militantes avaliam o conhecimento da história do hip-hop, seja nos Estados Unidos ou no Brasil, como critério para distinção entre militantes e artistas vinculadas a algum elemento "avulso" do movimento.

Esse interesse na história do hip-hop suscita algumas questões. O fomento ao conhecimento acerca das experiências da população negra da África à Diáspora, inclusive sobre os movimentos negros e suas lideranças, especialmente nos Estados Unidos e no Brasil; e o estímulo a uma formação política e à militância embasada nesta história social e nas atualidades apontam para a necessidade de maiores informações sobre os outros movimentos que dele se aproximem. É o que Eliciana coloca quando fala que "a história que 
a gente conhece aqui do Hip-Hop, que a gente aceita é essa, que o Hip-Hop, ele surge como um elemento politico, de resolver os conflitos sociais".

Segundo Eliciana, nos Estados Unidos o Hip-hop não é mais reconhecido dessa maneira politizada, pois atualmente carrega uma conotação muito comercial, distinta da luta por cidadania com qual os movimentos sociais estão comprometidos. ${ }^{83}$ Para ela, a versão defendida pelo movimento soteropolitano é a de receber algo que é fora, do "estrangeiro", porém essa versão também carrega uma conotação vinculada a uma herança negra:

A gente acredita em uma filosofia de hip-hop daqui, a gente alimenta isso o tempo todo, porque a gente reconhece a história do movimento Hip-hop desde a África, do nascimento do Griôs, da transição pros Estados Unidos por conta das guerras que aconteciam na África, da união dos quatro elementos lá e da propagação dele no mundo e até a chegada dele aqui no Brasil.

Essa interpretação exposta por Eliciana traduz a versão defendida pelo movimento soteropolitano que compreende o hip-hop como uma herança africana, baseado na cultura griô, a qual atuava com elementos artísticos para trabalhar a educação com jovens e adultos. Com o processo de diáspora da população negra, tanto seus elementos como o conhecimento em torno da cultura africana se dissipam pelo mundo. A rapper Paula escreveu sobre a relação do hip-hop e de seus elementos com a educação de jovens em sua graduação em Pedagogia, e resume qual é a sua preocupação e a do movimento em relação à história do hip-hop:

Sei, porque como integrante do movimento, primeiramente, eu sempre, eu sei que é necessário que a gente

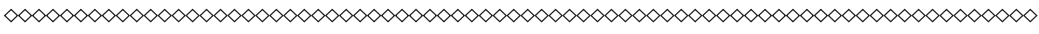

83 Durante a experiência do intercâmbio nos Estados Unidos citada anteriormente, pude perceber o incômodo que o hip-hop, e mais especificamente o rap, causava nas pessoas, o que me reteu de imediato à sensação vivenciada no Brasil em relação ao estilo do pagode com suas músicas e danças polêmicas. 
tenha essas informações, a gente não vai lutar por um movimento, está em um movimento sem saber como é que ele começou, as origens, onde ele está hoje, pra onde ele está se encaminhado.

É dessa forma crítica que esse movimento é construído pelas jovens hip hoppers, pois através dele promovem uma releitura acerca de sua própria realidade. Dessa mesma forma crítica e antenada essa juventude transforma e constrói seu próprio feminismo com a linguagem do hip-hop. É interessante perceber as oportunidades que uniram esses movimentos como em um processo social, num campo propício para criações de espaços de trocas de conhecimento. Esse diálogo entre os campos do feminismo e do hip-hop potencializou as mulheres em seus movimentos, como mostra Carla em sua experiência com os elementos do hip-hop:

A música e o break: eu acho que é muito palavra e corpo. Através do ra, justamente por conta de eu estar inserida no meio e de amizades mesmo, né, pra me apresentar esse mundo do rap, da música é... eu enquanto sujeita, no caso. Não enquanto uma pessoa que fica sentada ouvindo rap e tal; mas aí as amizades vêm no sentido de é... de eu poder me expressar também através da música, né. Eu também posso fazer música, eu também posso cantar né. E através do break, porque dentro dessa, desse espaço de militância do movimento Hip-hop né,e aí vem a discussão de gênero que a gente percebe que as mulheres, mesmo sendo um espaço de lutar contra a opressão, um espaço de resistência, como eu já falei, mas é um espaço também que reproduz muita coisa e aí a gente é, é... pesa muito sobre essa questão do corpo, como esse corpo se movimenta, como esse corpo fala também e o break eu tive contato a partir do, de um curso de formação né, formação de b-girl. 
O caso de Carla, em meio a atividades de desenvolvimento dos elementos do hip-hop, do rap e do break, mostra o movimento Hip-hop aberto para tratar de questões variadas, porém situadas e inseridas em um espaço político, "sendo um espaço de lutar contra a opressão, um espaço de resistência". Entretanto, como observação comum a todos os movimentos sociais, Carla afirma que mesmo com todo o caráter político contestatório das convenções sociais e de gênero embutido ao hip-hop, este "é um espaço também que reproduz muita coisa”. É um movimento que protesta contra as desigualdades e discriminações, mas também é um espaço em que essas violências acontecem, o que expõe o desafio posto ao próprio movimento, ponto de constantes críticas das hip hoppers.

Contudo, quando a pauta é o corpo, o diálogo entre o hip-hop e o feminismo se encontra nas formas de andar, vestir, falar, pintar e dançar. O hip-hop e o feminismo são capazes de tratar sobre múltiplas questões de movimento do corpo das mulheres e das convenções nas quais está envolto. Afirma Carla que "pesa muito sobre essa questão do corpo, como esse corpo se movimenta, como esse corpo fala também". O corpo é lido por essas jovens sob outra linguagem, que sofre interferências desta militância hip-hop e feminista ou de mulheres. Quando questionada como uma hip hopper percebe a interferência do movimento social em sua vida, seja ele o hip-hop ou feminismo, Negramone responde:

Interferem porque muda o corpo dessa pessoa, muda o estilo dessa pessoa, muda e acaba identificando pra essa pessoa quem ela é, de onde ela veio, a história dela que nunca foi contada. Influencia porque acaba sendo um conceito muito, como vou dizer, conceito conjunto e partindo dessas experiências que essa pessoa é, ela acaba sendo referência. Eu não gosto muito da palavra in- 
fluenciar, de influenciado. Gosto de palavras que possam suscitar, vamos dizer, referências. Porque quando uma criança vê sempre a televisão e vê sempre personagens de desenho brancos, elas vão querer ser, a referência pra ela é ser branca. Então, eu vou num conceito de referência, então as pessoas se sentem dentro das suas casas, elas se vêem, se vêem como pessoas políticas, como pessoas dinâmicas, como pessoas que podem construir uma nova sociedade, podem transformar onde vive, e podem falar porque a sociedade precisa disso, os jovens, na verdade, precisam disso e o hip-hop suscita essa lógica de você falar, de você falar das coisas que nunca foram colocadas pra você se manifestar, entendeu? Então, vai muito, muito mais direcionado pra isso. Pra essa essência mesmo da mulher, da mulher negra, do homem branco, do homem branco no sentido dele até se autoafirmar também, dentro dessa própria articulação, e pra saber de como racismo funciona, de como sexismo, de como o machismo funcionam. Contribui? Contribui pelo ser, acho que, contribui não... Acho que ainda contribui... Não só contribuiu pra algumas coisas, e contribui pra... Contribuiu pra eu ser a pessoa que sou hoje, por saber o contexto da minha realidade, de que estado eu vivo, de que país é esse e contribuiu pra eu entender que nem tudo que a gente vê é o que é.

A interferência dos conhecimentos adquiridos na experiência de militância no movimento social é responsável por transformações na visão de mundo dessas jovens, porque " muda o estilo dessa pessoa, muda e acaba identificando pra essa pessoa quem ela é". (Negramone) Essas ideias de autoconhecimento do indivíduo, de assumir sua identidade, de se reconhecer ou se sentir representada por alguém, e o reconhecimento de seu próprio poder de transformação da sociedade onde se vive são resultados 
de um processo de politização e empoderamento dessas jovens que "se veem como pessoas políticas, como pessoas dinâmicas, como pessoas que podem construir uma nova sociedade". (Negramone)

Conforme afirma Negramone em seu depoimento, "o Hip-hop suscita essa lógica de vocêfalar, de você falar das coisas que nunca foram colocadas pra você se manifestar", ou seja, o movimento se apresenta como um estímulo à reflexão, provocando as mulheres a pensarem sobre si mesmas, sobre o lugar onde moram, a situação do transporte de sua cidade, a lógica de beleza da mídia ou qualquer outro assunto sobre o mundo à sua volta. Elas são convidadas a se situarem, a terem uma opinião e conhecerem um pouco mais sobre elas mesmas, ao mesmo tempo em que esse conhecimento interfere no reconhecimento de suas referências: "Contribuiu pra eu ser a pessoa que sou hoje, por saber o contexto da minha realidade”. Diante dessa contextualização do possível diálogo entre hip-hop e feminismo, essa jovem apresenta subsídios para pensar acerca de um novo segmento dos movimentos sociais feministas e do hip-hop.

\section{Hip-hop feminista}

Em resposta à pergunta: "Você acha que é possível um hip-hop feminista?", as entrevistadas se surpreenderam com a expressão utilizada, o que foi recebido como uma reação inusitada. Depois, foi considerado que até o momento eu, como pesquisadora, não tinha referência de tal expressão no trabalho de campo ou na literatura. Como resultado da questão, a maioria das entrevistadas, exceto uma delas, acredita que seja possível ou mesmo que já exista esse hip-hop feminista.

De acordo com Negramone, este poder de transformação se traduz em criação quando ela explica que "Eu acho que é possível 
um hip-hop feminista, um hip-hop masculinista, um hip-hop indígena, acho que somos seres humanos e temos todas as possibilidades de criar". Para justificar a construção desse tipo de hip-hop e de feminismo, Carla se baseia em sua identidade racial e questiona se esse feminismo apenas seja possível e de interesse das e para as mulheres.

Sim. Hip-hop feminista, que bonito. Eu acho que é possivel sim um hip-hop feminista e eu acho que a gente faz isso né, acho que o grupo que faço parte tem essa/ Leva um pouco essa ideia do hip-hop feminista, que a gente questiona muito esses papéis da questão de gênero, né? Também dentro da nossa música e aí pegando o que eu falei, questão de gênero e de raça muito e a nossa sobrevivência mesmo enquanto mulheres né, mulheres negras. Eu acho que é, é/ Eu já vivo num hip-hop feminista, né? A gente espera que não seja só, só praticado por homens, mas que o hip-hop feminista seja praticado por/ Não. Não só por mulheres, mas que também seja praticado pelos homens, o hip-hop feminista, que eu acho que isso ai ta longe, mas é possivel, a gente acredita nisso.

Como informa a rapper, esse hip-hop feminista é identificado como referência para o grupo do qual participa, no caso, a banda de rap Munegrale. É Dina que, não apenas responde a questão colocada, como a justifica e exemplifica as expressões possíveis deste hip-hop feminista na atuação das militantes nos elementos artísticos do movimento.

PESQUISADORA: E tu achas que é possivel um feminismo, um hip-hop feminista?

DINA: Não só é possível como já existe, já existe. 
PESQUISADORA: Fala um pouquinho desse hip-hop feminista.

DINA: É quando as meninas pegam o microfone, são feministas, é quando a menina vai pro grafite, quando a menina diz que coisas de menino também são coisas de menina. Agora os meninos precisam saber que coisa de menina também é coisa de menino, agora nós já sabemos que coisa de menino é coisa de menina também, então é por isso que a gente faz, que algumas meninas têm feito, eu não digo tanto eu agora, mas já fiz a minha parte e as meninas estão dando continuidade.

Quanto à relação dos hip hoppers homens com esse tipo de hip-hop, será dada atenção em seção posterior, devido a não apenas ser um tema frequente nas falas das hip hoppers, mas também por faz parte de uma classificação e de questões sobre os hip hoppers, de acordo com suas posturas em relação às mulheres e ao feminismo. Apenas uma das entrevistadas respondeu de forma negativa à possibilidade de um hip-hop feminista. Ela explica o motivo para sua discordância baseada na experiência de outro movimento. Vivian responde:

Eu acredito que não. Porque assim é... o movimento negro tá aí com suas... vários buracos que aconteceram e dentro do movimento do MNU mesmo, de onde eu vim também, de onde eu venho, tem as mulheres feministas que acabaram criando um movimento dentro do movimento negro, hoje em dia elas não são mais do MNU, por essa conta. [...] De uma geração que vem do $M N U$, que elas criaram o movimento feminista lá dentro e que acabou com esse resultado, e uma coisa que o Hip-hop mesmo não quer, que são mulheres fazerem outro movimento ali dentro. Eu acredito que seja mulheres pra estar lutan- 
do igual a igual [...] Eu quero que cheguem mais mulheres e que a gente tenha autonomia de ficar igual a igual, de botar, pegar, fazer um show de rap, [...] e eu quero que seja igual pra igual sem... como me chamar de 'cara', levantar a mão e dizer eu sou 'cara' não, eu sou moça, mas que precisa criar outro... E que ele se reeduquem né! Eu acredito muito nisso.

Há uma preocupação de que o feminismo separe os grupos constituídos por homens e mulheres, como relato do ocorrido em outro grupo do movimento negro, o que aponta que existem problemas a serem discutidos. Contudo, para melhor compreender acerca desse "hip- hop feminista" procurei aprofundar o conhecimento acerca das concepções de feminismos construídas pelas jovens mulheres militantes, concepções essas que as orientam e estão sendo (re)produzidas em suas práticas políticas.

\section{Hip-hop feminista e suas concepções de feminismos}

Na pesquisa de campo em Salvador, as noções sobre feminismo apontaram para uma politização para além do comportamento ou estilos de se vestir das hip hoppers. Com a mesma forma crítica que se envolveram com o hip-hop, essas jovens veem o feminismo como um conjunto de discussões em torno dos aspectos de classe, raça e sexualidade, que mapeiam a própria história das mulheres e a história do feminismo.

O que as hip hoppers soteropolitanas definem por feminismo? Dentro disso, elas se colocam como feministas? Que tipos de feminismos podem ser identificados em suas falas? E quais são as questões centrais que as motivam ou as fazem rechaçar, ou mesmo ressignificar o feminismo? Na busca por conhecer as concepções sobre o feminismo que embasa esse hip-hop feminista, nas falas 
das hip hoppers foram identificadas três relevantes questões: 1) Da sexualidade e autonomia das mulheres; 2) Da raça e da classe; e 3) $\mathrm{Da}$ (des)substancialização do feminismo em relação às mulheres.

\section{Da sexualidade ${ }^{84}$ e do corpo das mulheres}

O feminismo traz consigo a história da luta das mulheres no mundo, sendo compreendido como um movimento que defende os direitos das mulheres. Além de ser visto como uma forma de vida que orienta diferentes possíveis visões de mundo, o feminismo também se dedica à própria relação das mulheres com o seu corpo. Negramone explica sua posição acerca dessas questões:

Eu entendo feminismo como uma política transversal, uma política em que discute a questão da mulher, a questão racial, a questão, vamos dizer, de estado também e da questão da sexualidade como um todo. Então eu entendo como uma filosofia de vida, como uma filosofia de vida e de vida mesmo dessas mulheres [...]. As dificuldades são muito universal, principalmente, quando se toca na questão de ser mulher, jovem, negra e por ter orientação sexual afetiva diferente da norma, são vastas, então, sóo fato você ter essa dificuldade dos próprios, vamos dizer, companheiros de movimento, os próprios companheiros de movimento não deixar que você possa realizar uma coisa que vai ser interessante para o próprio movimento nessas discussões de gênero, nas questões da masculinidade dos homens dentro do movimento, na construção de uma sociedade menos sexista, machista, homofóbica.

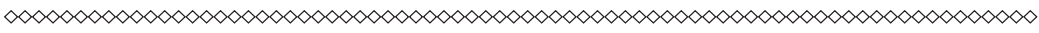

84 Segundo Jeffrey Weeks (2000, p. 25), "a sexualidade tem a ver com nossas crenças, ideologias e imaginações tanto quanto com o nosso corpo físico". 0 autor continua sua exposição do tema afirmando que "os corpos não têm nenhum sentido intrínseco e que a melhor maneira de compreender a sexualidade é como um 'cons-truct-histórico'”. (WEEKS, 2000, p. 25) Nesse sentido, a sexualidade está para além do corpo, estando situada ao contexto histórico e cultural de cada indivíduo, a exemplo das jovens hip hoppers soteropolitanas, que trazem consigo sua bagagem social expressa em seu corpo. 
Para Negramone, feminismo é "uma política transversal", "uma filosofia de vida" que tem como prioridade as mulheres e que dialoga com as categorias que as identificam em sua identidade racial, sexual, entre outras que a rodeiam. Carla também contribui com esse debate quando afirma ser reduzido o número de mulheres no movimento em comparação com o número de homens. Em detrimento desse contexto, as mulheres são recepcionadas pelos homens no movimento, questionadas a partir de seus corpos, como relata Carla: "o primeiro olhar da dúvida, duvidar do potencial da menina e o outro olhar que é tipo de seduzir mesmo aquela menina, acham que aquela menina é pra do lado deles que tá lá no movimento".

A $b$-girl Priscila destaca a autoestima e a confiança quando afirma que acredita que feminismo "é quando a gente cuida da gente, é quando a gente corre atrás de nossos objetivos, quando a gente luta por aquilo que a gente quer". É como se o feminismo pudesse impulsionar a força que cada mulher tem dentro se si para a realização de suas metas pessoais e profissionais. Já para Paula, feminismo é sinônimo de luta contra o machismo, termo utilizado pela rapper. Paula já dá indícios do debate sobre quem pode ser machista: homens e mulheres podem? Esse debate ficará para a seção posterior que tratará da (des)substancialização do feminismo de acordo com as hip hoppers.

Feminismo é o sistema que a gente criou pra se autodefender, não só dos homens, mas do sistema o machismo. Que a meu ver não tá somente integrado na relação homem - mulher, o machismo é uma coisa que já ta tão arraigada na sociedade que até uma mulher pode ser machista [...]. Como uma forma de luta, de busca de nós mulheres, cada uma com as suas realidades, a mulher negra com a sua, a mulher branca com a sua, a mulher indígena com a sua, cada uma com seu olhar, do seu ângulo continuando a luta. 
Dina concorda com Paula que o machismo atinge a todas as mulheres, independente de sua identidade étnico-racial. Por isso, ela defende o feminismo como a luta das mulheres pelo direito de decidir. Para ela, "feminismo é a busca por autonomia das mulheres, estas mulheres brancas, mulheres negras e mulheres indígenas, é autonomia, a luta dessa autonomia, isso é ser feminista, eu entendo por â". ${ }^{85}$ Dina é questionada se ela se considera feminista e responde: "Sim, lógico, eu sou uma feminista negra, lógico que sim”. Essa afirmação nos leva à próxima questão sobre o diálogo do feminismo com as questões de raça e classe discutidas pelas hip hoppers.

\section{Da raça ${ }^{86}$ e da classe ${ }^{87}$}

A questão colocada sobre um "feminismo negro" como referência para as hip hoppers foi muito recorrente nas atividades e conversas desse movimento de mulheres. Contraposto a um movimento de mulheres brancas e de classe média, o feminismo negro apresenta-se como uma polêmica, pois tem base na pluralidade dos feminismos e das experiências das mulheres.

Os movimentos sociais e os lugares de fala dessas jovens devem ser compreendidos para explicar as bases que orientam os seus pensamentos acerca do feminismo negro. Para tanto, Paula faz uma distinção do feminismo em relação a mulheres negras e mulheres brancas, tendo como base a situação de classe. Ela aponta um caso que se embasa na discussão em torno da possibilidade de um compartilhamento de responsabilidades quanto à divisão de tarefas domésticas por um casal.

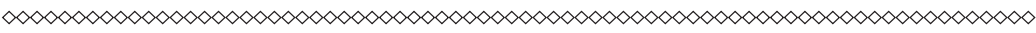

85 Fala da entrevistada Paula.

86 Raça é aqui entendida como política que remete à identidade constituída a partir dos aspectos que ligam o pertencimento a um grupo histórico não apenas pela cor da pele e fenótipo, mas também pela autoafirmação e resgate da ancestralidade.

87

Classe compreende um extrato social que se baseia na média de renda econômica compartilhada por um grupo, o que também abrange aspectos como estilo de vida e visão de mundo. 
Porque a gente tem uma visão do feminismo sobre a ótica branca de fazer feminismo. 'Ah! Eu sou feminista porque eu não cozinho, porque eu não vou lavar cueca de ninguém, porque eu não vou varrer a casa, porque eu tenho que ir pro trabalho', não é isso. Eu acho que enquanto mulher, eu não faço isso por que eu sou mulher, faço isso porque eu acho legal, cuidar do meu marido eu acho legal, varrer a casa eu acho legal, eu acho legal lavar os pratos, eu acho legal enfeitar a casa. E ele também faz a mesma coisa.

A distinção já se apresenta na visão de que trabalho doméstico reuniria tarefas negativas a serem feitas e compartilhadas por um casal. A ideia da rapper procura desassociar uma divisão sexual do trabalho, bastante questionada pelo feminismo, de uma divisão de tarefas em que as mulheres são sobrecarregadas com a exclusividade de responsabilidade com as tarefas do lar, como lavar, passar, arrumar a casa etc. Entretanto, ela interpreta negativamente as reivindicações do feminismo a partir de um maniqueísmo entre brancas/negras e pobres/ricas, ao tratar as mulheres brancas como que excluídas da realidade dessa sobrecarga de tarefas, pois o feminismo dito como "branco", para ela, se nega à realização de tais funções próprias da dinâmica de uma casa, especialmente por compreender esse feminismo por um veio de representação de uma classe dominante, o que não é exatamente tão preestabelecido desta forma na sociedade.

Carla também contribui com esse debate quando destaca a distinção de sua compreensão sobre a história do feminismo, ao pensar a trajetória e experiências das mulheres brancas europeias e as mulheres negras brasileiras desde o período da escravidão no país:

Entendo por feminismo uma forma coletiva de se lutar por direitos iguais entre homens e mulheres. Entendo 
feminismo também não só a história do feminismo da Europa, mas a história do feminismo de como se configurou aqui entre as mulheres negras também, no Brasil. E ai vem a discussão de que se é movimento de mulher ou feminismo? Acredito, por exemplo, que as irmandades que existiam aqui, que lutavam e juntavam dinheiro pra comprar alforria do escravo, eu entendo isso como feminismo. Essas mulheres organizadas em prol de uma causa assim, eu entendo como feminismo.

Pode-se afirmar que essa crítica racial e de classe em torno de um feminismo de referência branca e europeu se apresenta fortemente entre as hip hoppers soteropolitanas. Diante de referências de mulheres brancas e de classes que tiveram um acesso a maior escolaridade, esse feminismo é reconhecido como algo “intelectual”, e branco. É um dos aspectos que difere das próprias experiências das mulheres negras, que historicamente tiveram menos oportunidades de acesso ao ensino e, consequentemente, menos oportunidade de registros intelectuais de suas próprias experiências.

Quando questionadas sobre seu entendimento do feminismo, as hip hoppers logo se remeteram à ideia de estudos, escritas, algo da academia, tendo este como um conhecimento registrado e também como uma forma de contato com esse pensamento. Essa vinculação do feminismo à leitura conota ligação com uma classe que teve acesso à educação e a uma maior escolaridade, no caso, as mulheres que produziram registros escritos sobre suas experiências sob uma perspectiva crítica das relações de poder é que seriam as feministas. Entretanto, essas questões apresentam-se como ambivalentes diante de uma demanda do próprio movimento Hip-hop com relação à preocupação com acesso à educação e ao conhecimento, bandeiras que podem ser exemplificadas na luta por ações afirmativas no ensino superior e pela implementação da 
história e cultura africana e afro-brasileira nos currículos escolares. Mais uma vez, a questão de classe pode ser identificada diante do entendimento às críticas das hip hoppers ao feminismo:

PESQUISADORA: O que é feminismo para você?

ELICIANA: Mas assim, eu acho que é a rebeldia feminina de ser feminina e de lutar pelo direito de ser feminina, de ser mulher e de não deixar que o machismo tome conta se si mesma. E acho que alguma coisa assim da história do feminismo que eu me lembro é que, falando de revoluções de mulheres, assim, que aconteceram, uma coisa que eu sempre ouço é que enquanto as mulheres brancas estavam queimando sutiã, as mulheres negras estavam incendiando fazendas! Eu não sei se você já ouviu isso, já ouviu né!? Que é a coisa mais linda, mais forte que eu ouço, porque dentro dessa ideia de feminismo, o pouco que eu já li, já ouvi sobre feminismo, porque a gente sabe como é diferente ser mulher negra, ser mulher é foda, mas ser mulher negra é foda num sei quantas vezes! E a gente tem que ter uma rebeldia de feminista muito maior, muito maior.

Nos anos de 1970, ocorreu uma eclosão de movimentos em diversas partes do mundo sob o lema de reivindicações de direitos. Segundo Matilde Ribeiro (1995), é diante de um contexto de ditadura militar que o movimento Feminista ressurge no Brasil, com pautas que encabeçavam a vida particular e privada envolvendo temas como sexualidade, direito à creche para filhos e filhas de trabalhadores, liberdade sexual, além de igualdade salarial, representação política e políticas públicas para mulheres. Entretanto, a questão racial e das mulheres negras estava de fora. Época de eclosão, também, dos movimentos negros interessados na luta por cidadania no país no bojo das lutas antirracistas internacionais que 
marcaram a "década da mulher" pela ONU. A própria organização das mulheres negras apenas se efetiva em meados dos anos de 1980 no país, priorizando questões em torno de uma tríplice militância, que incidiam no combate à discriminação das mulheres negras e pobres.

As pautas desse movimento abarcavam pontos como: combate aos estereótipos que estigmatizam as mulheres negras; inserção no mercado de trabalho com o questionamento ao tratamento diferenciado de oportunidades e salários entre mulheres negras e brancas, regulamentação do trabalho doméstico, entre outros. Esse argumento baseia a fala de Vivian:

Assim, eu não [pausa] eu posso dizer assim: eu nunca me adaptei muito em ler sobre o que é feminismo, porque eu tinha muita resistência por dizer que é um movimento de mulheres brancas, eu não sou feminista, eu digo muito isso, eu sou feminina, porque desde adolescente vi que o movimento Feminista é um movimento de mulheres brancas, e aí então não me identifico, mas eu acho que é um movimento de mulheres que luta pela sua liberdade, pela... pelos direitos que elas tem na sociedade que por causa delas serem mulheres elas não tem.

Em sua fala, Vivian reativa a discussão da separação entre movimento Feminista e Movimento de Mulheres, ${ }^{88}$ debate que tem dado subsídio para a afirmação de um Movimento de Mulheres negras, mas sem um consenso em torno da questão. Já Carla agita mais esse debate quando aponta um Movimento de Mulheres negras e feministas.

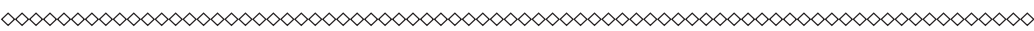

88 Para as autoras Ana Alice Costa e Cecilia Sardenberg (1994), o que distingue o movimento Feminista do Movimento de Mulheres é justamente a estruturação em torno da doutrina feminista e o questionamento da situação das mulheres na sociedade, e não apenas pela simples reunião de mulheres por questões específicas, que não incidam diretamente no reconhecimento ou transformação do lugar onde elas se encontram. 
A luta por igualdade e também a luta pela sobrevivência. Sobrevivência das mulheres e das suas famílias. Que aí eu me remeto muito ao movimento de como as mulheres negras que vieram pro Brasil se organizaram e tentaram sobreviver, mas aí pensando não só na sobrevivência dela, mas pensando na sobrevivência dos filhos, dos maridos também. Eu entendo isso como feminismo, mas não só por mulheres, mas que também seja praticado pelos homens, o hip-hop feminista, que eu acho que isso aí está longe, mas é possível, a gente acredita nisso.

O feminismo reconhecido como combate às desigualdades entre homens e mulheres aparece como possível estratégia de luta contra o machismo, a ser construída por homens e mulheres. Mas o feminismo é para homens e mulheres? Ambos podem se afirmar feministas? Essas questões nos levam para nossa última seção.

\section{Da (des)substancialização do feminismo}

Uma das concepções de feminismos encontradas nas falas das hip hoppers envolvia questões como: homens e mulheres feministas e machistas e feminismo para os homens a partir das suas experiências dentro do movimento. Questões essas que promoveram uma espécie de (des)substancialização do feminismo.

A relação entre homens e feminismo foi um tema vigente em falas como a de Carla: "Não só por mulheres, mas que também seja praticado pelos homens, o hip-hop feminista, que eu acho que isso aí está longe, mas é possível, a gente acredita nisso!". O combate contra a opressão às mulheres aparece como uma alternativa aos homens, também responsáveis por essa transformação social construída pelo que seria esse hip-hop feminista. É o que Paula coloca: "É possível, é real, ele já existe. A gente faz, nós somos mulheres e feministas, não feministas porque somos mulheres, mas somos mulheres feministas, como tem homens 
feministas também”. A rapper faz uma distinção entre ser feminista e ser mulher e abriu uma discussão polêmica entre as próprias feministas, a qual gira em torno dos homens feministas.

Pode haver homens feministas e mulheres machistas? Para Paula, "o machismo é uma coisa que já está tão arraigada na sociedade que até uma mulher pode ser machista". O hip- hop reconhece que este sistema de valores "machista" pode ser alterado diante de uma meta que objetiva uma (re)educação para homens e mulheres.

Totalmente, hoje com o ideal de ter uma organização que seja autossustentável, que faça a gente se autogerir, é muito mais um desejo de conseguir desenvolver os trabalhos com esse público, com essas mulheres, com esses homens também, os homens precisam de uma atenção no sentido de se (re)educarem [risos]. Meu objetivo é fazer esse movimento ser grande, que ele já é. Mas, sei lá, ser mais uma pessoa que chegou pra, que chegou que tá chegando, que tá indo, que tá se instrumentalizando pra fazer o movimento da gente crescer, se fortalecer e continuar ser diferente do movimento estadunidense que é vendido na mídia.

Essa é a preocupação em manter o hip-hop como compromisso de transformação social, apontando para uma postura diferenciada deste movimento em relação ao que (re)produz discriminações e ao que está "vendido na mídia". Este hip-hop feminista seria possível de educar homens para o feminismo. Embora os hip hoppers não tenham sido entrevistados, não é comum ver homens se colocando como feministas. Porém, segundo Paula "Conheço alguns homens feministas, o meu parceiro é feminista. Ele me cobra o tempo inteiro que eu não me atenta às atitudes machistas, ele é feminista. Têm outros, outros parceiros, 
vários outros". Já Dina é mais comedida e afirma que "nós temos homens que são sensíveis à nossa causa, nós temos poucos".

A necessidade de uma nova perspectiva de ação para homens no hip-hop perpassa por uma nova forma de olhar sobre o machismo, de acordo com Eliciana. Pode ocorrer que, o que os homens acham que seja colaboração e parceria para com as mulheres, não seja exatamente isso.

Assim, eu acho que, sei lá, tem muita coisa pra avançar ainda, que vai desde as letras de música, da tentativa que eu vejo dos caras de tentar fazer alguma coisa pras mulheres, mas que porra, eu já vi coisas assim de que, por velho, fique calado, não fale isso não, não tenta ajudar a gente não porque você tá prejudicando, deles tentarem, tipo: 'Ah, eu sou o cara que estou do lado das mulheres, mas olha o que eu estou falando!'.

Esses foram alguns dos temas que se destacaram em campo e que são desafios em contínuo embate dentro da militância no hip-hop, no que se refere às convenções de gênero e feminismo nesse movimento. Essa juventude sabe que esta é uma luta constante contra as discriminações, em suas várias faces. Contudo, o que essas jovens têm construído como "hip-hop feminista" une movimentos feministas e de mulheres, movimentos negros e movimentos jovens, e se constitui um instrumento possível para contribuir com essa transformação social, por ser contestatório das desigualdades, especialmente em relação às mulheres. É o que se resume e se conclui na fala de Dina quando ela responde sobre as expectativas para o futuro:

Ah, são tantas, minhas expectativas é que realmente o MHH assim como outros movimentos que eu faço parte, eles realmente comecem a mudar na sua total, mudar mesmo, mudar em que sentido, assim, principalmente 
em relação a nós, mulheres, que os homens comecem, a maioria dos homens, que hoje nós temos homens que são sensíveis à nossa causa, nós temos poucos, mas eu acho que a minha expectativa é que daqui a um tempo todos os homens que venham a adentrar no MHH eles percebam que para ele estar ali dentro, ele precisa ter uma relação de gênero resolvida na cabeça dele, precisa entender essa relação para mudar entendeu, então essa é a minha expectativa, não entre no hip-hop porque 'ah, agora eu sou rapper', não, não, eu sou rapper porque eu quero fazer algo diferente, a minha relação com as mulheres vai mudar, porque eu entendo que esse movimento me propicia isso entendeu?

As hip hoppers construíram esse hip-hop feminista para empoderarem a si mesmas e às suas ações no movimento social, enquanto adentram nesse espaço político e inserem sua pauta. Pauta essa que está vinculada à contestação das convenções de gênero que geram as normas sociais em torno do masculino e do feminino, e orientam as próprias relações sociais vivenciadas por essas jovens, as quais desejam mudanças.

\section{Considerações finais}

O movimento de mulheres hip hoppers soteropolitano esteve no centro desta pesquisa, a qual investigou as convenções de gênero e feminismos nesse movimento social. Voz dos discriminados por denunciar as desigualdades sociais em torno das realidades dos grupos de jovens negros pelo mundo, o hip-hop também contesta as convenções de gênero em torno do masculino e feminino, ao passo que se transforma em um instrumento de luta e espaço de atuação das mulheres. 
A militância dessas jovens foi analisada a partir do questionamento de que elas reforçavam ou ressignificavam as convenções de gênero no hip-hop. O objetivo foi o de compreender, segundo a formulação das interlocutoras, o que era "coisa de menina" e "coisa de menino" no hip-hop. A partir da atuação das jovens foram elencados inúmeros desafios para que elas adentrassem no espaço do movimento, que era tido, inicialmente, como um espaço majoritariamente formado por homens. Entretanto, o hip-hop continha uma "brecha" para atuação das mulheres, a qual permitiu não só a inserção dessas jovens em contato com suas artes de rua, mas também a oportunidade de influenciar em pautas, em ações e na própria configuração do hip-hop soteropolitano desde sua criação no ano de 1990.

Seus contatos com artes do hip-hop ocorreram por meio da socialização entre jovens, motivados por inquietações em torno de suas situações de classe e raça vivenciadas pela juventude negra e pobre de Salvador. O que era compartilhado por outras juventudes, a exemplo da juventude negra estadunidense, que inicia o movimento inspirada em sua realidade de exclusão e nos ensinamentos dos movimentos civis e black power em seu país.

Entretanto, o que permitiu a compreensão das jovens do hip-hop como um movimento de contestação das convenções de gênero foi sua apropriação de mais um movimento social. As lições dadas pelo movimento Feminista em relação ao combate às desigualdades que afligiram as mulheres fomentaram uma apropriação acerca desse pensamento, que configurou as concepções de feminismo que estão sendo (re)produzidas na prática política das jovens mulheres militantes do movimento Hip-hop soteropolitano.

Essas concepções de feminismos, somadas às pautas já instituídas do movimento, proporcionaram a existência de um hip-hop feminista local. Com o intuito de avançar em relação à compreensão da pluralidade do feminismo como movimento social, 
foram comparadas as formas de apropriação e adaptações, pelos sujeitos da pesquisa, dos discursos feministas e das formas de engajamento das hip hoppers. Essas questões foram apreendidas na tensão entre suas concepções e suas práticas cotidianas relativas às demandas do movimento Hip-hop, bem como no papel desempenhado pela articulação entre os marcadores de gênero, sexualidade e raça na militância.

Como resultados encontrados, os principais argumentos que formataram esses discursos analisados das interlocutoras parceiras da pesquisa com base na crítica sobre uma concepção de um feminismo visto como branco e de referência europeia, tido como mantenedor das desigualdades entre as mulheres de diferentes classes e raças. Em sua militância, as hip hoppers desafiam e (re)significam os movimentos feministas com os quais estão em diálogo quando apreendem o feminismo, compreendido como a luta pela autonomia da sexualidade das mulheres, mas escolhem a referência dos feminismos que traduzem as experiências das mulheres negras, pobres e trabalhadoras.

A partir de suas concepções de feminismo, essas jovens construíram a possibilidade de um hip-hop feminista a partir da reflexão de três vertentes dos movimentos sociais: movimento Feminista, movimento Negro e movimento da Juventude. Nas falas das interlocutoras surgiram questões em torno de uma (des)substancialização do feminismo, devido ao questionamento acerca da essencialização da relação mulher-feminismo, especialmente por considerações acerca da postura dos homens no movimento, os quais foram classificados de três diferentes formas: homens machistas, homens sensíveis à causa dos direitos das mulheres, e homens feministas.

Dessa discussão, o que vale ressaltar é a responsabilidade que esse movimento assume com relação à transformação social no diálogo entre cultura e política voltado para a juventude. 
Conclui-se que, como um movimento social, o Hip-hop dialoga com a cultura política local ao mesmo tempo em que a desafia, ao definir pautas e estratégias políticas de reivindicação de direitos e de combate às desigualdades em geral e de gênero em particular.

A maior dificuldade ainda hoje é a lógica machista, a lógica machista de funcionar as coisas. Porque o machismo ele nunca me atingiu, ele nunca me atingiu, porque o machismo não atingir mulheres como nós, porque a gente sabe lidar com ele, ou aprendeu a lidar e o objetivo da gente que outras mulheres saibam, aprendam a lidar também com o machismo. Mas dentro do hip-hop o que me incomoda e o que me deixa mais... O que me preocupa é a lógica machista de funcionar, porque a todo tempo por mais que a gente esteja ali, mulheres na luta, conseguindo coisas e conquistando coisas, as barreiras elas sempre... elas permanecem. Parece que a cada vez que a gente fica mais forte, mais forte os muros são, os tijolos do machismo são cada vez mais empilhados, mais forte, eles usam um cimento mais forte, uma coisa mais impermeável. E aí a gente tem que ganhar outras habilidades, hoje eu estou no rap, amanhã eu posso dançar break e depois eu posso tocar disco e depois eu posso grafitar e depois eu posso... enfim, fazer, inventar um outro elemento, ou ter um outro elemento, entendeu, a gente tem sempre que se superar, esse é o maior desafio do hip-hop, que eu me sinto quando mulher no hip-hop. Porque a sociedade e o grupo onde a gente tá inserida sempre cobra mais da gente. E ver também que tem irmãs que não conseguem se superar, não consegue superar essa lógica e a gente pensa que ela tá indo, ela não tá indo, ela tá voltando. (PAULA) 
A relevância de conhecer a perspectiva das mulheres em suas experiências no Hip-hop soteropolitano registra a história do próprio movimento. Assim, é o hip-hop feminista soteropolitano mais uma das expressões que compõem a pluralidade dos movimentos feministas, o que aponta os desafios, as possibilidades e a criatividade dessas mulheres jovens negras de fazerem arte, bem como explorarem o campo do político. 


\section{Referências}

ALVAREZ, S. E. Feminismos latinoamericanos. Estudos Feministas, Florianópolis, v. 6, n. 2, 1998.

ALVES, A. P. Do blues ao movimento por direitos civis: o surgimento da "blackmusic" nos Estados Unidos. Revista de História, Salvador, ano 3, n. 1, 2011.

ASANTAWAA, M. Mulher. In: BUZO, A. (Org.). Pelas periferias do Brasil. São Paulo: 2008.

ÁVILA, M. B. Feminismo e sujeito político. Proposta, Rio de Janeiro, 1 mar. 2000. Disponível em: <http://www.appsindicato.org.br/include/ paginas $/$ noticia.aspx ?id=25>. Acesso em: 15 jan. 2009.

ÁVILA, M. B. Radicalização do feminismo, radicalização da Democracia [S:1:s:n]. 2007. Disponível em: <http://soscorpo.org/wp-content/ uploads/Radicalizacao_doFeminismo_radicalizacao_daDemocracia MBAvila2007.pdf>. Acesso em: 6 dez. 2008.

BARRETO, P. C. S. Múltiplas vozes: racismo e anti-racismo na perspectiva dos universitários de São Paulo. Salvador: Edufba, 2008.

BARROS, Z. Casais inter-raciais e suas representações acerca de "raça”. Salvador: Empresa Gráfica da Bahia, 2007.

BARROS, Z. Eu gosto dela. [S.1.]. 26 nov. 2007. Disponível em: <https:// www.youtube.com/watch? $\mathrm{v}=2 \mathrm{MWEJWC4VCw}>$. Acesso em: $6 \mathrm{fev}$. 2008.

BILL, M. Roda Viva, São Paulo, 2005. Disponível em: <http://www. rodaviva.fapesp.br/materia_busca/318/Mv\%20bill/entrevistados/ mv_bill_2005.htm>. Acesso em: 7 mar. 2008. 
BOBBIO, N.; MATTEUCCI, N.; PASQUINO, G. Dicionário de Política. Brasília, DF: Editora UnB, 2000.

BONETTI, A. L. Entre femininos e masculinos: negociando relações de gênero no campo político. Cadernos Pagu, Campinas, n. 20, 2003.

BONETTI, A. L. Eu não sou feminista, sou feminina! relações de gênero e atuação política entre mulheres de grupos populares porto-alegrenses. In: LISBOA, M. R. A.; MALUF, S. W. (Org.). Gênero, cultura e poder. Florianópolis: Mulheres, 2004.

BONETTI, A. L. Não basta ser mulher, tem que ter coragem: uma etnografia sobre gênero, poder, ativismo feminino popular e o campo político feminista do Recife - PE. 2007. 258 f. Tese (Doutorado em Ciências Sociais) - Universidade Estadual de Campinas, Campinas, 2007.

BONETTI, A. L.; FONTOURA, N. O. Convenções de gênero em transição no Brasil? Uma análise sobre os dados de família na PNAD 2007. In: CASTRO, J. A.; RIBEIRO, J. A. C. (Org.). Situação social brasileira: 2007. Brasília, DF: IPEA, 2009.

BONETTI, A. L.; FONTOURA, N. O.; MARINS, E. Sujeito de Direitos? cidadania feminina nos vinte anos do Constituição Cidadã. Políticas sociais: Acompanhamento e análise, Brasília, DF, v. 3, n. 17, 2009.

BOURDIEU, P. A representação política: elementos para uma teoria do campo político. In: BOURDIEU, P. O poder simbólico. 11. ed. Rio de Janeiro: Bertrand Brasil, 2007. cap. 7.

BRITO, M. N. C. Gênero e cidadania: referenciais analíticos. Estudos Feministas, Florianópolis, v. 9, ano 9, n. 1, 2001. Disponível em: <http://www.scielo.br/pdf/ref/v9n1/8616.pdf>. Acesso em: 27 jun. 2005.

CARDOSO, R. C. L. A trajetória dos movimentos sociais. In: DAGNINO, E. (Org.). Os anos 90: política e sociedade no Brasil. São Paulo: Brasiliense. 1994.

CARVALHO, J.; QUINTILIANO, R. Conquistas e desafios à participação política de jovens mulheres negras. In: PAPA, F. C.; SOUZA, R. (Org.). Jovens Feministas presentes. Brasília, DF: UNIFEM, 2009. p. 92-103.

CLAY, A. "Like and old soul record": black feminism, queer sexualiaty, and the hip -hop generation. Meridians, Michigan, v. 8, n. 1, p. 53-73, 2008. 
COLLINS, P. H. From black power to hip hop: racism, nationalism, and feminism. Philadelphia: Temple University Press, 2006.

COSTA, A. A. A.; SARDENBERG, C. M. B. Feminismos, feministas e movimentos sociais. In: BRANDÃO, M. L. R.; BINGEMER, M. C. L. (Org.). Mulher e relações de gênero. São Paulo: Loyola, 1994. p. 81-113.

COSTA, A. A. A. As donas no poder: mulher e política na Bahia. Salvador: Núcleo de Estudos Interdisciplinares sobre a Mulher, 1998.

COSTA, A. A. A.; SOBRAL, R.; SANTANA, E. As mulheres e as marchas da família com Deus pela democracia e pela liberdade na Bahia. In: MOTTA, A. B.; AZEVEDO, E. L; GOMES, M. (Org.). Reparando a falta: dinâmica de gênero em perspectiva geracional. Salvador: Núcleo de Estudos Interdisciplinares sobre a Mulher, 2005. p. 135-152. (Coleção Bahianas).

DAGNINO, E. (Org.). Os anos 90: política e sociedade no Brasil. São Paulo: Brasiliense, 1994.

DAGNINO, E.; ALVAREZ, S. E. ; ESCOBAR, A. (Org.). Cultura e política nos movimentos sociais latino-americanos: novas leituras. Belo Horizonte: Ed. UFMG, 2000.

DOIMO, A. M. A vez e a voz do popular: movimentos sociais e participação política no Brasil pós-70. Rio de Janeiro: Relume-Dumará, 1995.

DURHAM, A.; COOPER, B. C.; MORRIS, S. M. The stage hip-hop feminism built: A new directions essay. Signs, Spring, v. 38, n. 3, 721-737, 2013.

FERNANDES, F. A. G. O que a história do movimento hip-hop pode nos ensinar?. Fronteira: Revista de História, Dourados, v. 9, n. 16, jan./jul. 2007. Disponível em: <http:// ojs.ufgd.edu.br/index.php/FRONTEIRAS/ article/view/38/49>. Acesso em: 28 jun. 2008.

FREIRE, R. S. Participação politica das mulheres jovens: hip hop e (novo) movimento social em Salvador (1996-2009). 2010. $95 \mathrm{f}$. Monografia (Bacharelado em Ciências Sociais) -Universidade Federal da Bahia, Salvador, 2010.

GASKELL, G. Entrevistas individuais e grupais. In: BAUER, M. W.; GASKELL, G. (Ed.). Pesquisa qualitativa com texto, imagem e som: um manual prático. Tradução de Pedrinho A. Guareschi. Petrópolis: Vozes, 2002. p. 64-89. 
GEERTZ, C. Do ponto de vista dos nativos: a natureza do entendimento antropológico. In: GEERTZ, C. Saber local: novos ensaios em antropologia interpretativa. Tradução de Vera Mello Joscelyne. Petrópolis: Vozes, 1997. p. 85-107.

GILROY, P. Jóias trazidas da servidão: música negra e política da autenticidade. In: GILROY, P. Atlântico negro: modernidade e dupla consciência. São Paulo: Ed. 34, 2001. p. 157-222.

GÓES, W. L. Com a palavra, a periferia. Toques de Angola, Brasília, DF, ano 2, n. 3, 2004.

GOHN, M. G. O paradigma dos novos movimentos sociais. In:

GOHN, M G. Teoria dos movimentos sociais: paradigmas clássicos e contemporâneos. São Paulo: Loyola, 1997. p. 121-170.

GOHN, M. G. Movimentos sociais na atualidade - manifestações e categorias analíticas. In: GOHN, M G. (Org.). Movimentos sociais no início do século XXI: antigos e novos atores sociais. Petrópolis:

Vozes, 2003. p. 13-32.

GOHN, M. G. Movimentos Sociais: espaços de aprendizagem coletiva. Revista de Educação, Salvador, ano 12, n. 46, set./nov. 2004.

GOHN, M. G. Educação não-formal e cultura política: impactos sobre o associativismo do terceiro setor. 3. ed. São Paulo: Cortez, 2005.

GOMES, R. C. S. Relações de gênero e rock'n'roll: um estudo sobre as bandas femininas de Florianópolis. In: PRÊMIO CONSTRUINDO A IGUALDADE DE GÊNERO, 3., 2008, Brasília, DF. Anais... Brasília, DF: Presidência da República, Secretaria Especial de Políticas para Mulheres, 2008.

GREGORI, M. F. Cenas e queixas: um estudo sobre as mulheres, relações violentas e prática feminista. Rio de Janeiro: Paz e Terra, 1993.

HALL, S. Pensando a diáspora: reflexões sobre a terra no exterior. In: HALL, S. Da diáspora: identidades e mediações culturais. Tradução de Adelaine La Guardiã Resende. Belo Horizonte: Ed. UFMG, 2003. p. 25-50.

HARAWAY, D. Saberes localizados: a questão da ciência para o feminismo e o privilégio da perspectiva parcial. Cadernos Pagu, Campinas, n. 5, p. 7-41, 1995.

ISOKE, Z. Women, hip-hop, and cultural resistance. Souls, Dubai, [S.1.], v. 15, n. 4, 316-337, 2013. 
LACLAU, E. Novos movimentos sociais e Estado na América Latina. Revista do CEDLA: Latin American Studies, Amsterdã, n. 29, 1983.

LIMA, M. S. Rap do batom: família, educação e gênero no universo rap. 2005. 124 f. Dissertação (Mestrado em Educação) - Universidade Estadual de Campinas, Campinas, 2005.

LIMA, A. C. C. Saltando e quebrando: o rap... pensar identidades no trânsito entre Bahia e o Maranhão. 2006. 165 f. Dissertação (Mestrado em Ciências Sociais) - Universidade Federal da Bahia, Salvador, 2006.

MARTINS, F. S. Rap, juventude e identidade. In: SOUSA, J. G. et al. (Org.). Educando para os direitos humanos: pautas pedagógicas para a cidadania na Universidade. Porto Alegre: Síntese, 2004.

MATSUNAGA, P. S. Mulher no hip hop: identidades e representações. 2006. 209 f. Dissertação (Mestrado em Educação) - Universidade Estadual de Campinas, Campinas, 2006.

MATSUNAGA, P. S. As representações sociais da mulher no movimento hip hop. Psicologia e Sociedade, Florianópolis, v. 20, 2008.

MIRANDA, J. H. A. Relação de mercado e trabalho social no hip-hop. Caderno do CEAS, Salvador, n. 223, jul./set. 2006.

MORAES NETO, V. A ressignificação dos elementos do movimento hip hop na cidade de Salvador. 2006. 110 f. Monografia (Bacharelado em Sociologia) - Universidade Federal da Bahia, Salvador, 2006.

MOTTA, A. B. (Org.). Dossiê: gênero, idades e geração. Salvador: Edufba, 2004.

NORONHA, F. Onde estão as $b$-girls? A pesquisa antropológica numa roda de break. In: BONETTI, A.; FLEISCHER, S. (Org.). Entre saias justas e jogos de cintura. Florianópolis: Mulheres, 2007. p. 185-206.

NÚCLEO DE ESTUDOS INTERDISCIPLINARES SOBRE A MULHER - NEIM. Se liga, galera!!! Diga não à Violência Contra a Mulher. Salvador, 2005. Disponível em: <www.neim.ufba.br/wp/wp-content/ uploads/2013/11/seliga.pdf>. Acesso em: 7 mar. 2008.

NUNES, E. A gramática política do Brasil: clientelismo e insulamento burocrático. Rio de Janeiro: Jorge Zahar, 1997.

OLIVEIRA, A. P. C. Movimento hip hop: educação em quatro elementos. 2007. 77 f. Monografia (Bacharelado em Pedagogia) - Universidade Federal da Bahia, Salvador, 2007. 
PHILLIPS, A. De uma política de idéias a uma política de presença?. Estudos Feministas, Florianópolis, v. 9, n. 1, 2001. Disponível em: <http://dx.doi.org/10.1590/S0104-026X2001000100016〉. Acesso em: 28 fev. 2007.

PINHO, O. A. Etnografia do brau: corpo masculinidade e raça na reafricanização de Salvador. Estudos Feministas, Florianópolis, v. 13, n. 1, jan./abr. 2005.

RIBEIRO, M. Mulheres negras brasileiras: de Bertioga a Beijing, Revista Estudos Feministas, Florianópolis, v. 3, n. 2, p. 446-458, 1995.

SADER, E. Quando novos personagens entram em cena construção de sujeitos: experiências, falas e lutas de trabalhadores da Grande São Paulo (1970- 80). São Paulo: Paz e Terra, 1988.

SAFFIOTI, H. I. B. Rearticulando gênero e classe. In: COSTA, A. O.; BRUSCHINI, C. (Org.). Uma questão de gênero. Rio de Janeiro: Rosa dos Tempos, 1992. p. 183-215.

SAFFIOTI, H. I. B. Contribuições feministas para o estudo da violência de gênero. Cadernos Pagu, Campinas, n. 16, 2001.

SALES, C. M. V. Juventude, política e relações de gênero: o jovem enquanto sujeito político. In: ENCONTRO INTERNACIONAL DA REDE FEMINISTA NORTE E NORDESTE DE ESTUDOS E PESQUISA SOBRE A MULHER E RELAÇÕES DE GÊNERO, 8., 1999, Fortaleza. Anais... Fortaleza: REDOR, 2001.

SANSONE, L. Funk baiano: uma versão local de um fenômeno global? In: SANSONE, L.; SANTOS, J.T. (Org.). Ritmos em trânsito: sócioantropologia da música baiana. São Paulo, 1997. p. 219-240.

SANTOS, A.; SUNEGA, F. Hip Hop mulher: experiências de organização. In: PAPA, F. C.; SOUZA, R. Jovens Feministas presentes. Brasília, DF: Unifem, 2009.

SARDENBERG, C. M. B. Da crítica feminista à ciência: uma ciência feminista? In: COSTA, A. A. A.; SARDENBERG, C. M. B. (Org.).

Feminismo, ciência e tecnologia. Salvador: REDOR, 2002. p. 89-120. (Coleção Bahianas).

SARDENBERG, C. M. B. O gênero da memória: lembranças de operários e operárias. In: ASSOS, E.; ALVES, I.; MACEDO, M. Metamorfoses: gênero na perspectiva interdisciplinar. Salvador: NEIM/UFBA, 1998. (Coleção Bahianas). 
SAUNDERS, T. Towards a transnational hip-hop feministliberatory praxis: a view from the Americas, Social Identities, [S.1], v. 22. n. 2, 178-194, 2016.

SILVA, M. A. O rap das meninas. Estudos Feministas, Florianópolis, v. 3, n. 2, 1995.

SIMPLES RAP'ORTAGEM. Quadro Negro. [Salvador]: Universidade Federal da Bahia, 2005.

SCOTT, J. Gênero: uma categoria útil de análise histórica. Recife: SOS Corpo e Cidadania, 1992.

SOUZA, A. M. O movimento do rap em Florianópolis: a ilha da magia é só da ponte para lá!. 1998. 177 f. Dissertação (Mestrado em Antropologia Social) - Universidade Federal de Santa Catarina, Florianópolis, 1998.

SOUZA, A. M. A caminhada é longa... e o chão tá liso: o movimento hip hop em Florianópolis e Lisboa. 2009. $332 \mathrm{f}$. Tese (Doutorado em Antropologia Social) - Universidade Federal de Santa Catarina, Florianópolis, 2009.

SOUZA, G. L.; SANTOS, S. G. Tobossis - Virando a Mesa "Hip Hop" Parte 1/3, [Salvador], [2009]. Disponível em: <https://www.youtube. com/watch? v=bwN8aIPAY6M $>$. Acesso em: $28 \mathrm{fev} .2007$.

TELLES, V. S. Sociedade civil e a construção de espaços públicos. In: DAGNINO, E. (Org.). Os anos 90: política e sociedade no Brasil. São Paulo: Brasiliense, 1994.

WEEKS, J. O corpo e a sexualidade. In: LOURO, G. L. (Org.). O corpo educado: pedagogias da sexualidade. 2. ed. Tradução de Tomaz Tadeu da Silva. Belo Horizonte: Autêntica, 2000. p. 35-82.

WELLER, W. A construção de identidade através do hip hop: uma análise comparativa entre rappers negros em São Paulo e rappers turnosalemães em Berlim. Cadernos CRH, Salvador, n. 32, 2000.

WELLER, W. A presença feminina nas (sub)culturas juvenis: a arte de se tornar visível. Estudos Feministas, Florianópolis, v. 13, n. 1, 2005. Disponível em: <http://www.scielo.br/pdf/ref/v13n1/a08v13n1.pdf>. Acesso em: 3 fev. 2006.

WHITE, W. F. Sociedade da Esquina [Street Corner society]: a estrutura social e uma área urbana pobre e degradada. Tradução de Maria Lúcia de Oliveira. Rio de Janeiro: Jorge Zahar, 2005. 
ZANETTI, J.; SOUZA, P. L. A. Jovens no feminismo e no Hip Hop na busca por reconhecimento. In: PAPA, F. C.; SOUZA, R. (Org.). Jovens Feministas presentes. Brasília, DF: Unifem, 2009. p. 104-113.

ZINE hip hop em movimento. Posse ORI. Salvador, n. 2, 2002. ZINE origens. Posse Ori Movimento Hip Hop. Salvador, n. 4, 2004. 


\title{
POSFÁCIO \\ Rumo à práxis de um Hip-hop brasileiro feminista: uma introdução ${ }^{99}$
}

\author{
Dra. Tanya L. Saunders \\ Professora Associada \\ Universidade da Flórida
}

A partir do momento em que abri este livro eu sabia que o Hip-hop feminista? Convenções de gênero e feminismos no movimento Hip-hop soteropolitano seria um livro importante. A autora, Rebeca Sobral, fez uma importante contribuição aos estudos do hip-hop, ao novo campo de estudos do hip-hop feminista, aos estudos feministas, aos estudos culturais e à teoria dos movimentos sociais. O livro começa com as questões centrais: há um hip-hop feminista de base jovem sediado na cidade de Salvador? Há hip hoppers feministas? Se assim for, o que é o hip-hop feminista e como ele influencia noções de gênero em Salvador/BA? Devo observar aqui que essas são as questões formais apresentadas pela autora em seu texto. O livro também envolve 
questões mais amplas sobre a práxis política e a negociação contínua do que constitui a "cidadania" no Brasil para pessoas normalmente excluídas dos processos políticos. Especificamente, o hip-hop, como um dos muitos movimentos sociais centrados na esfera cultural, desafia o que constitui um "cidadão" e que deve ser incluído em noções emergentes de cidadania no pós-ditadura no Brasil.

Muitas vezes, os movimentos sociais que ocorrem dentro da esfera cultural não são considerados movimentos sociais ou mesmo como sendo políticos. O que o livro de Sobral faz é intervir nesses discursos com o intuito de suscitar transformações em suas cabeças. Desenho dos principais estudiosos das Ciências Sociais no domínio da política cultural, a autora faz uma importante contribuição para os estudos acadêmicos emergentes e a pesquisa empírica sobre os movimentos sociais baseados nas artes. Ela usa esta pesquisa acadêmica para contextualizar um fenômeno social importante, o papel significativo que o hip-hop está exercendo no ativismo das mulheres em Salvador/BA, o tempo todo, considerando suas implicações a nível local e nacional.

O uso feito por Rebeca da etnografia e observação participante combinados com dados de entrevistas é guiado também pela metodologia feminista. Ou seja, no prazo de métodos de pesquisas feministas a estudiosa desenvolve uma pesquisa fundamentada empiricamente, a qual também busca superar preconceitos na pesquisa acadêmica, contribui para a mudança social, reflete a diversidade humana e reconhece a posição de pesquisadora. Sobral realiza tudo isso a tal ponto que também apresentou suas descobertas com as comunidades nas quais conduziu sua pesquisa.

Mais importante ainda, qualquer pesquisadora experiente entende que os métodos de pesquisa que uma estudiosa escolhe dependem da questão de pesquisa. Ou seja, se o objetivo da 
pesquisadora é compreender fenômenos sociais emergentes, então é importante ter tempo para observar e coletar dados sobre o referido fenômeno. Essa abordagem é importante para definir o terreno para futuras pesquisas em novas e importantes áreas de atividade social e política, uma vez que haverá um ponto de partida estabelecido para contextualização futura e comparação. A questão de pesquisa de Sobral é simples e importante: como esse fenômeno - especificamente ativismo hip-hop - tem se autoapresentado e como ele tem tido um impacto documentado sobre a sociedade e seus indivíduos? Como podemos avançar na análise desse fenômeno social? Os resultados de sua pesquisa renderam a documentação de um movimento social feminista que aborda questões centrais sobre cidadania, apresentadas por uma população muitas vezes excluída dos processos políticos estabelecidos. Além disso, e justamente por isso, a intervenção dessas ativistas ocorre na área da cultura.

A autora localiza a cena hip-hop em Salvador dentro de um movimento social nacional maior. Ela, então, situa esse movimento social nacional maior dentro da literatura sobre movimentos sociais de base cultural. Usando a literatura sobre movimentos sociais de base cultural, movimentos sociais feministas, dos jovens e dos movimentos sociais negros no Brasil, Sobral desafia a construção do que é considerado como a participação política legítima. Sobral desafia a ideia de que a cultura não é política, quando na verdade todos os movimentos sociais agem em uma política cultural. Ao situar o movimento Feminista Hip-hop no Brasil no nexo de vários movimentos sociais - negro, feminista e centrado de mulheres e movimentos sociais baseado em jovens -, ela cria o espaço necessário para começar a analisar a organização das mulheres dentro do hip-hop como um movimento social em Salvador, especificamente um movimento social feminista (ou de mulheres). A maneira com que Sobral trabalha essa importante 
intervenção permite futuros cientistas sociais serem capazes de estudar algo que soa claramente um sinal para examinar, como ela afirma, as mudanças geracionais, especificamente sobre como a política cultural é realizada por novas gerações de ativistas.

Após os primeiros capítulos situarem pesquisas e descobertas de Sobral, no final de três capítulos do texto a autora apresenta seu trabalho. No capítulo três, Sobral desenha sua experiência etnográfica participando de eventos de hip-hop em Salvador. Ela escreveu que não sabia o que esperar em primeiro lugar, se por um show ou outro tipo de evento artístico. O que ela percebeu foi que esses eventos eram realmente reuniões. Eles foram reuniões de conscientização centradas em capacitar mulheres jovens para participarem em eventos de hip-hop e/ou trabalharem para mudar a sociedade em geral.

Esses eventos tiveram títulos como "Lugar de mulher também é no hip-hop" e suas atividades desafiaram diretamente a natureza centrada no masculino do ativismo hip-hop para argumentar que as mulheres também são parte ativa e importante desse movimento e, num sentido mais amplo, da mudança social. Sobral extrai de seus dados de entrevistas a citação de uma rapper chamada Dina, que argumenta que os homens ocuparam espaço dentro do hip-hop, mas o seu acesso ao público é realmente baseado em uma questão cultural, e não é um resultado de algo particular do movimento.

Dina argumenta que as mulheres precisavam ser fortalecidas e prontas para encarar estes homens que detêm um processo cultural mais longo de dominar o espaço público e os movimentos políticos, e para dizer “Não é assim! Este espaço é nosso!”. Uma das intervenções que essas mulheres fazem é desafiar a estética, simbolicamente masculina, que tem sido comumente usada dentro do hip-hop. Isto é, a fim de serem levadas a sério, esperava-se que as mulheres usassem roupas masculinas. Rappers 
desafiaram isso como uma maneira de criar espaço para as mulheres também serem capazes de falar e serem levadas a sério como sujeitos femininos. Ao refletir sobre a diversidade de discursos do hip-hop nos Estados Unidos, Sobral também situa sua discussão sobre a diversidade das mulheres centrada nas perspectivas feministas dentro do movimento. Ela também destaca que o hip-hop soteropolitano (hip-hop da cidade de Salvador) é centrado em um nexo de mulheres e/ou ativismo feminista nacional conferido pela presença de artistas de hip-hop de várias cidades ao redor do país.

Uma questão central formulada pelas participantes (artistas e público em geral) em eventos do hip-hop é: o que é uma mulher, especificamente, e o que é uma mulher dentro do hip-hop? Através do envolvimento nessa questão, as artistas e o público em geral que participam nas conferências, simpósios e outros eventos organizados por artistas começam a desconstruir práticas de gênero e as formas em que as próprias mulheres, através de uma solidariedade expressa com os homens, continuam a reproduzir, inadvertidamente, muitos dos discursos que estavam trabalhando para mudar.

Sobral se concentra em intervenções das mulheres artistas nas quatro expressões artísticas chaves ou elementos do hip-hop: dança Break, MCing, DJing e graffiti. Todas as mulheres enfrentam diferentes formas de discriminação quando têm oportunidades para expor sua arte, pois são assumidas para não serem tão boas quanto os homens. No entanto, um dos aspectos interessantes do trabalho de Sobral é a comparação do modo como as mulheres e a feminilidade são entendidas em cada uma das formas de arte em que escolheram para expressar a sua energia criativa. Ela descobre que break-dancers, talvez, enfrentem o maior desafio de dança Break em si, pois contestam quase todos os aspectos das construções sociais de feminilidade, em especial, tornando a autonomia 
corporal das mulheres visíveis. O que Sobral fez aqui, através de sua análise perspicaz, foi articular uma importante área para pesquisas futuras: grande parte das pesquisas sobre as mulheres no hip-hop não consideram as políticas de gênero de cada um dos seus elementos e nivelam as experiências das mulheres que participam de cada uma dessas formas de arte. Ao considerar as experiências das mulheres dentro de cada uma das quatro expressões artísticas do hip-hop, podemos realmente saber mais sobre as experiências das mulheres de diversas perspectivas dentro do hip-hop em si.

Sobral localiza o hip-hop dentro de outras tradições culturais negras globais, como o funk. O hip-hop, como uma esfera pública racializada e uma cultura de música negra, surgiu como um espaço no qual a juventude negra pôde começar a se sentir habilitada, divertir-se, aprender e até mesmo cultivar uma autoestima mais forte em face de uma sociedade racista e sexista. As artistas entrevistadas sentiram que o hip-hop era uma empresa profundamente social, centrada na coletividade e na transformação social, além de um movimento que dialoga com quase todos os movimentos sociais no país. Isso é algo que eu também encontrei na minha pesquisa em Cuba intitulada Hip-hop Underground Cubano (Cuban Underground Hip-hop); como uma esfera pública racializada, também serviu como um nexo para os inúmeros movimentos sociais que ocorrem dentro da esfera cultural de Cuba. Isso não deveria surpreender como as vidas, experiências e interesses de pessoas afrodescendentes são diversas também.

Nos capítulos quatro e cinco Sobral faz suas mais fortes contribuições teóricas, extraídas de seus dados etnográficos, da observação participante e dados de entrevistas. No capítulo quatro, aborda os desafios discursivos das mulheres artistas do hip-hop quanto à forma e sobre como o gênero é entendido e experimentado, alternando desde a discussão sobre a família e a violência 
contra as mulheres, até a abordagem da diversidade sexual. A luta pela autonomia corporal das mulheres também tem sido um aspecto chave central das mulheres hip-hop ativistas.

No capítulo cinco, Sobral aborda a questão se há ou não realmente um hip-hop feminista. Nesse capítulo, ela apresenta a diversidade de teorias e autodefinições articuladas pelas artistas sobre seu ativismo como mulheres dentro do hip-hop. Variando de mulheres que se identificam com o feminismo e com o hip-hop feminista em particular, às mulheres que se distanciam do feminismo por causa da história do intelectualismo eurocêntrico, baseado em classe, que é associado ao termo. Não me deterei nos detalhes desse capítulo, porque acredito que aqui Sobral reúne todos os segmentos de seus textos e constrói um forte argumento para pensar se esse movimento centrado nas mulheres é um movimento social feminista. O que eu gostaria de fazer aqui, no entanto, é oferecer algumas considerações baseadas no campo emergente de estudos de hip-hop feministas nos Estados Unidos, como uma maneira de colocar o trabalho de Sobral e o trabalho dessas artivistas - ativistas que usam a arte para fazer suas intervenções políticas e trabalhar para a mudança social - em diálogo um com o outro.

Debates semelhantes sobre a política de identidades feministas surgiram entre as gerações mais jovens de mulheres que formam a primeira geração do hip-hop nos Estados Unidos. Após a comercialização do hip-hop, o lugar das mulheres nas letras de hip-hop e vídeos foi deslocado no imaginário para uma esmagadora maioria sexista e racista. As mulheres jovens que foram habilitadas pelo hip-hop e desenvolveram sua consciência política através dele foram taxadas por muitas feministas, particularmente feministas brancas americanas, como pessoas participando de sua própria opressão. 
Feminismo hip-hop como práxis feminista explícita surgiu na década de 1990, como um termo cunhado e teorizado por Joan Morgan em seu livro When Chickenheads Come Home to Roost (1999). O fato de que o feminismo hip-hop veio com o surgimento de estudos de hip-hop na década de 1990 não deve ser uma surpresa. As mulheres negras sempre foram uma parte em que desempenhou um papel fundamental nos movimentos sociais negros neste hemisfério - como Sobral argumenta em seu livro. Intelectuais negros, como Joan Morgan, escreveram que a precipitação da década de 1960 teve um impacto sobre a juventude negra que cresceu durante esse período; um efeito que se confunde com a forma do período de desindustrialização, condicionada ao ritmo impresso às ondas de globalização dos anos 1970 e 1980. Morgan (1999 apud SAUNDERS, 2016, p. 182) afirma:

Eu sou apoio, no entanto, por um feminismo que exige assumirmos a responsabilidade por nossas vidas. Na minha busca para encontrar um feminismo funcional para mim e minhas sistas - um que busca a capacitação espiritual, material, física, e nos níveis emocionais... Precisamos de uma voz como a nossa música - com sons de muitas vozes sobrepostas ${ }^{90}$ que injetem suas sensibilidades no velho e o transformem em algo novo, provocador e poderoso. E aquele cuja ocasional hipocrisia, contradições e banalidade nos garante, pelo menos, algumas divagações, forçando-nos a finalmente confrontar todos os sentimentos represados. [minha ênfase adicionada] ${ }^{91}$

O trabalho de Durham, Cooper e Morris, certamente, complementa a chamada. Morgan aponta para um feminismo que

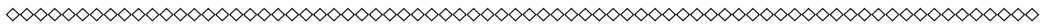

90 Sample é um termo utilizado na música, em música eletrônica, são "batidas" que significa inserir acordes de outras músicas - os DJs usam muito.

91 No original "I am down, however, for a feminism that demands we assume responsibility for our lives. In my quest to find a functional feminism for myself and my sistas - one that seeks empowerment on spiritual, material, physical, and emotional levels ... We need a voice like our music - one that samples and layers many voices, inject its sensibilities into the old and flips it into something new, provocative, and powerful. And one whose occasional hypocrisy, contradictions, and trite- ness guarantee us at least a few trips to the terror-dome, forcing us to finally confront what we'd all rather hide from. [my emphasis added]" 
reflete os materiais, experiências espirituais, físicas e emocionais de mulheres. Ao tomar mais de uma abordagem diaspórica para compreender o feminismo hip-hop, Durham, Cooper e Morris (2013, p. 722) definem o feminismo hip-hop como:

[A] articulação de uma específica geração de uma consciência feminista, epistemologia e política enraizada no trabalho pioneiro de várias gerações de feministas negras com sede nos Estados Unidos e em outros lugares na diáspora, mas com foco em questões e problemas que crescem fora das prerrogativas estéticas e políticas da cultura hip- hop.

A inclusão da "diáspora" é uma referência à Diáspora Africana, por isso eu acho que é tão importante colocar os artistas e o trabalho de Sobral em conversa com os estudos feministas de hip-hop estadunidenses: temos a possibilidade de fortalecer e reforçar o feminismo hip-hop como movimento Feminista do século XXI, trazendo as vozes da diáspora numa conversa mais ampla sobre a relação entre o hip-hop e as formas contemporâneas de práxis feminista negra diaspórica. Como Isoke (2013, p. 317) argumenta em sua discussão, a importância de

subjetividades translocais em enquadramento de análises de expressão política das mulheres negras globais...como locais específicos se relacionam entre si e ressoam uns com os outros como uma forma de cruzamento de fronteiras culturais e construção de pontes. ${ }^{92}$

Assim como feministas negras, pessoas negras não normativas e queer sempre fizeram parte da esfera pública negra. Muito parecido com o que os hip hoppers brasileiros artivistas estão fazendo, estudiosos como Adreanna Clay trouxeram visibilidade ao LGBT e

$\infty<\infty<\infty<\infty<\infty<\infty<\infty<\infty<\infty<\infty<\infty<\infty<\infty<\infty<\infty<\infty<\infty<\infty<\infty<\infty<\infty<\infty<\infty<\infty<\infty<\infty<\infty<\infty<\infty<\infty<\infty$

92 As Isoke (2013, p. 317) argues in her discussion of the importance of 'translocal subjectivities in framing analyses of global black women's political expression ... how specific locales relate to one another and resonate with one another as a form of cultural border crossing and bridgebuilding.' 
populações queer que também fazem parte da geração hip-hop. Em seu artigo "Like and Old Soul Record: Black Feminism, Queer Sexualiaty, and the Hip-Hop Generation" argumenta que a artista Me'Shell Ndegochello marca uma virada importante no feminismo negro e reflete as complexidades e contradições do feminismo hip-hop. (CLAY, 2008, p. 53)

O que eu gostaria de salientar aqui é o seguinte: desde a sua concepção, o feminismo nas Américas surgiu com a participação de mulheres negras. Nos Estados Unidos, por exemplo, dos discursos mais notáveis ao longo dessa história tem-se o discurso "Não sou mulher?", dado por Sojounet Troth (1797-1883), que nasceu na escravatura. Ela proferiu esse discurso em 1827, na Convenção das Mulheres em Akron, Ohio. Naquele momento, ela desafiou a concepção das mulheres feministas brancas sobre mulheres negras e igualdade das mulheres.

Uma coisa que eu gostaria ressaltar é que apesar do feminismo ser um termo usado para descrever o ativismo centrado nas mulheres, este, que existia antes desse termo ser cunhado, também as considera feministas. Assim, o termo "feminismo" não deve continuar a ser restringido à análise do ativismo centrado das mulheres brancas, pois nas Américas as mulheres negras foram certamente envolvidas no ativismo centrado das mulheres, a partir do momento em que chegaram a este hemisfério.

Além disso, as mulheres negras têm sido fundamentais na produção da história que o termo "feminismo" descreve. É por essa razão que o feminismo hip-hop é considerado uma forma de feminismo negro nos EUA, e a razão pela qual eu acho que é importante incluir as mulheres hip-hop ativistas como "hip-hop ativistas feministas”, mesmo se elas não se identificam como "feministas hip-hop". Ou melhor, mesmo que algumas mulheres nem sempre se identifiquem como feministas, é importante a pesquisa acadêmica que considera as intervenções teóricas centradas 
de mulheres ativistas - e aqui estou incluindo mulheres trans -, alegando o termo "hip-hop feminista", como uma forma de reconhecer a história formativa que as mulheres negras têm desempenhado no surgimento de várias conceituações de feminismo.

Bolsistas pesquisadoras devem continuar o trabalho de reconhecer a participação formativa das mulheres negras no surgimento da práxis feminista, como membros ativos de esferas públicas locais, nacionais e internacionais, mesmo se o ativismo das mulheres negras continuar a ser destituído por formas canônicas de estudos acadêmicos. No entanto, dado o trabalho inovador de estudiosas acadêmicas como Rebeca Sobral, fico animada ao saber que, independentemente de se decidir usar o termo "feminista", womanist ou outro termo ativista centrado nas mulheres, as intervenções políticas das mulheres negras pela transformação da sociedade em geral estão cada vez mais sendo documentadas dentro da pesquisa acadêmica, bem como recebem cada vez mais a consideração teórica e empírica que ela certamente merece. Uma realização refletida no hip-hop feminista. 


\section{GLOSSÁRIO \\ (vocabulário do universo hip-hop)}

Batalha: demonstrar a competição entre graus de habilidade na elaboração das ideias, seja em elementos do hip-hop, como a rima, o grafite, o break ou na evolução vinil.

Beat: a batida que pode ser criada através da pickup ou do próprio som da boca

BeatBox: o beat produzido pela boca

B-boy: garoto que dança break

B-girl: garota que dança break

Break: a dança

DJ: Disk Jockey (Tocador de discos), quem embala festas usando aparelhos de disco, realizando mixagens e scratc.

Djeia: Feminino de DJ, mulher que toca disco

Fanzine: material jornalístico informal que viabiliza a divulgação de informações, neste caso, do movimento

Freestyle: rap improvisado

Feedback: experiência de colaboração/troca, acordos entre indivíduos ou grupos do $\mathrm{MHH}$ e pesquisadoras/es do tema 
Grafite/Graffiti: artes plásticas do hip-hop, a pintura nos muros das cidades

Grafiteira (o): pessoa que trabalha com elemento das artes plásticas do hip-hop

Hip-hop: traduzido do inglês para o português significaria a união entre o balancear das ancas (hip) e o salto (hop)

MC: mestre de cerimônia responsável pelo beat

Pickup: é a aparelhagem do/s toca-disco/s trabalhando com as batidas e os efeitos na música através de técnicas como o scratch

Posse: organização ou grupo local de articulações do Hip-hop

Rap: a música, ritmo e poesia, o canto falado, acompanhado

Rapper: garota ou garoto que compõe/canta rap

Scratch: quando o vinil é tocado no sentido anti-horário através dos amarranhados no toca-discos, tratado enquanto instrumento musical, destacando partes escolhidas das canções. 


\begin{tabular}{r|l} 
Formato & COLOFÃo \\
Tipologia & x $23 \mathrm{~cm}$ \\
Papel & $\begin{array}{l}\text { Leitura News e leitura Sans 10/16 } \\
\text { Cartão } 75 \mathrm{~g} / \mathrm{m}^{2}(\mathrm{miolo})\end{array}$ \\
Impremo $300 \mathrm{~g} / \mathrm{m}^{2}$ (capa) & Edufba \\
Acabamento & Cartograf \\
Tiragem & 300
\end{tabular}

